\title{
ESTUDO MORFOLÓGICO DA SUPERFÍCIE RADICULAR E DO PERIODONTO DE DENTES SUBMETIDOS AOS PROCEDIMENTOS DE EXTRUSÃO ORTODÔNTICA RÁPIDA E EXTRUSÃO CIRÚRGICA EM CÃES
}

\section{SUNG HYUN KIM}

Tese apresentada à Faculdade de Odontologia de Bauru, da Universidade de São Paulo, como parte dos requisitos para obtenção do título de Doutor em Odontologia, área de concentração Periodontia.

(Edição Revisada)

\author{
BAURU
}

2003 


\section{ESTUDO MORFOLÓGICO DA SUPERFÍCIE RADICULAR E DO PERIODONTO DE DENTES SUBMETIDOS AOS PROCEDIMENTOS DE EXTRUSÃO ORTODÔNTICA RÁPIDA E EXTRUSÃO CIRÚRGICA EM CÃES}

\section{SUNG HYUN KIM}

Tese apresentada à Faculdade de Odontologia de Bauru, da Universidade de São Paulo, como parte dos requisitos para obtenção do título de Doutor em Odontologia, área de concentração Periodontia.

(Edição Revisada)

Orientador: Prof. Dr. Sebastião Luiz Aguiar Greghi

BAURU

2003 


\begin{tabular}{|l|}
\hline Kim, Sung Hyun \\
K56e \\
Estudo morfológico da superfície radicular e do \\
ortodôntica de dentes submetida e extrusão cirúrgica procedimentos de extrusãos. - Bauru, 2003. \\
147 p. : il. ; $30 \mathrm{~cm}$. \\
Tese. (Doutorado) --Faculdade de Odontologia \\
de Bauru. Universidade de São Paulo. \\
Orientador: Prof. Dr. Sebastião Luiz Aguiar Greghi
\end{tabular}




\section{Dados Curriculares Sung Hyun Kim}

Nascimento

Filiação

$1978-1981$

$1984-1985$

$1986-1991$

1989

$1999-2003$

Associações

02 de Maio de 1958

Seoul-Coréia do Sul.

Dong Chan Kim e

Yoon II Kim.

Curso de Odontologia - Pontifícia Universidade Católica do Paraná.

Curso de Especialização em Periodontia na Faculdade de Odontologia de Santo Amaro - SP.

Curso de Pós-Graduação em Periodontia em nível de Mestrado na Faculdade de Odontologia de Bauru - USP.

Professor do Centro de Ciências Biológicas e da Saúde da Pontifícia Universidade Católica do Paraná, Curso de Odontologia, Periodontia

Curso de Pós-Graduação em Periodontia em nível de Doutorado na Faculdade de Odontologia de Bauru - USP.

$\mathrm{ABO}$ - PR - Associação Brasileira de Odontologia - Secção Paraná 
Aos meus pais, Dong e Yoon pela formação

e exemplo de vida;

À Mônica, pelo amor, dedicação e companheirismo;

Aos queridos filhos André e Luca,

esperanças da minha vida,

DEDICO COM AMOR ESTE TRABALHO. 
Ao Professor Doutor Sebastião Luiz Aguiar Greghi,

orientador, mestre e amigo, pela seriedade e

competência, só assim tornando possível

a realização deste trabalho gratificante,

MEU MUITO OBRIGADO. 
Ao Professor Doutor Euloir Passanezi, responsável maior por minha formação científica, exemplo de mestre, pela oportunidade na concretização deste projeto,

MINHA GRATIDÃO E RESPEITO. 


\section{AGRADECIMENTOS:}

À Faculdade de Odontologia de Bauru, na pessoa do seu diretor Prof. Dr. Aymar Pavarini;

À comissão de pós-graduação, representada pelo Prof. Dr. Luiz Fernando Pegoraro;

Ao Conselho Nacional de Desenvolvimento Científico e Tecnológico (CNPq), pela bolsa de estudo concedida;

Ao professor Doutor Deoclécio Nahás "in memoriam", pelo exemplo de dedicação ao trabalho;

Ao Prof. Dr. Vinícius Augusto Tramontina, grande amigo e incentivador, pela participação e colaboração direta no experimento;

Ao Professor Doutor Antônio Carlos Marconi Stipp, pela colaboração na elaboração da metodologia;

Ao Diretor do Curso de Odontologia da PUCPR, Prof. Monir Tacla, pelo apoio e carinho cedidos na minha carreira acadêmica; 
Às Professoras do Curso de Medicina Veterinária da PUCPR, Antônia Maria e Cassiana, pela amizade, apoio e colaboração direta na execução do trabalho prático em animais;

À Prof. Dra. Maria Ângela Machado, pela amizade e orientação na avaliação das lâminas histológicas;

Às Professoras do programa de aprendizagem Periodontia PUCPR, Sônia, Vula, Rosângela e Ricardo pela amizade, apoio e estímulo contínuo;

Aos colegas de Pós-Graduação, Mônica, Daniel e Vinícius, pelo convívio fraterno e de muita amizade;

À Dani e àTânia do departamento de Histologia da FOB -USP, pelo apoio técnico no processamento das peças histológicas;

Às funcionárias do departamento de Periodontia da FOB-USP, Ivânia, Edilaine, Neuza e Marcão, pela amizade;

Aos Funcionários do Curso de Medicina Veterinária da PUCPR, Mário e Carmen, pela colaboração efetiva no cuidado dos animais; 
A todos os professores do curso de Pós-Graduação da Faculdade de Odontologia de Bauru, Universidade de São Paulo, todo o meu respeito e agradecimento;

E a todos que, de alguma forma, contribuíram para a realização deste trabalho. 


\section{SUMÁRIO}

LISTA DE GRÁFICOS IX

LISTA DE FIGURAS X X

LISTA DE ABREVIATURAS XVII

RESUMO XVIII

1 INTRODUÇÃO

2 REVISÃO DA LITERATURA

2.1 Reimplante Dentário 9

2.2 Extrusão Cirúrgica $\quad 29$

2.3 Extrusão Ortodôntica 35

3 PROPOSIÇÃO $\quad 42$

4 MATERIAL E MÉTODOS 44

5 RESULTADOS 58

6 DISCUSSÃO

7 CONCLUSÕES 127

$\begin{array}{ll}\text { REFERÊNCIAS BIBLIOGRÁFICAS } & 130\end{array}$

$\begin{array}{lr}\text { ABSTRACT } & 142\end{array}$

$\begin{array}{lr}\text { APÊNDICE } & 146\end{array}$ 


\section{LISTA DE GRÁFICOS}

\begin{tabular}{|c|c|}
\hline Gráfico 1 & $\begin{array}{l}\text { Tipos e graus de reabsorção e reparação. Médias } \\
\text { do período - } 7 \text { dias. Extrusão Cirúrgica. }\end{array}$ \\
\hline Gráfico 2 & $\begin{array}{l}\text { Tipos e graus de reabsorção e reparação. Médias } \\
\text { do período - } 7 \text { dias. Extrusão Ortodôntica. }\end{array}$ \\
\hline Gráfico 3 & $\begin{array}{l}\text { Tipos e graus de reabsorção e reparação. Médias } \\
\text { do período - } 14 \text { dias. Extrusão Cirúrgica. }\end{array}$ \\
\hline Gráfico 4 & $\begin{array}{l}\text { Tipos e graus de reabsorção e reparação. Médias } \\
\text { do período }-14 \text { dias. Extrusão Ortodôntica. }\end{array}$ \\
\hline Gráfico 5 & $\begin{array}{l}\text { Tipos e graus de reabsorção e reparação. Médias } \\
\text { do período - } 45 \text { dias. Extrusão Cirúrgica. }\end{array}$ \\
\hline Gráfico 6 & $\begin{array}{l}\text { Tipos e graus de reabsorção e reparação. Médias } \\
\text { do período - } 45 \text { dias. Extrusão Ortodôntica. }\end{array}$ \\
\hline Gráfico 7 & $\begin{array}{l}\text { Tipos e graus de reabsorção e reparação. Médias } \\
\text { do período - } 90 \text { dias. Extrusão Cirúrgica. }\end{array}$ \\
\hline Gráfico 8 & $\begin{array}{l}\text { Tipos e graus de reabsorção e reparação. Médias } \\
\text { do período - } 90 \text { dias. Extrusão Ortodôntica. }\end{array}$ \\
\hline Gráfico 9 & $\begin{array}{l}\text { Tipos e graus de reabsorção e reparação. Médias } \\
\text { do período - } 120 \text { dias. Extrusão Cirúrgica. }\end{array}$ \\
\hline Gráfico 10 & $\begin{array}{l}\text { Tipos e graus de reabsorção e reparação. Médias } \\
\text { do período - } 120 \text { dias. Extrusão Ortodôntica. }\end{array}$ \\
\hline Gráfico 11 & $\begin{array}{l}\text { Tipos e graus de reabsorção e reparação. Médias } \\
\text { do período - } 180 \text { dias. Extrusão Cirúrgica. }\end{array}$ \\
\hline Gráfico 12 & $\begin{array}{l}\text { Tipos e graus de reabsorção e reparação. Médias } \\
\text { do período }-180 \text { dias. Extrusão Ortodôntica. }\end{array}$ \\
\hline
\end{tabular}




\section{LISTA DE FIGURAS}

Pág

Figura 1 Aspectos clínicos das áreas selecionadas. 45 Observar as estruturas dentárias e periodontais clínicamente normais.

Figura 2

Desgaste da coroa dentária no nível cervical e 48 confecção dos aparatos para tração coronal ortodôntica do dente controle.

Figura 3 Início da tração ortodôntica do dente controle. Observe que o elástico ortodôntico em cadeia permanece estirado em posição tal que produz a extrusão do dente.

Figura 4

Término da tração ortodôntica do dente controle.

Veja que o dente encontra-se em contato com a ancoragem transversal, indicando o fim do movimento programado. É de se destacar, ainda, alguma mudança posicional da margem gengival, quando se compara com a figura anterior.

Figura 5 Desgaste no nível cervical do dente experimental para obter a mesma referência do dente controle vista na figura 2 para aplicação do procedimento de extrusão cirúrgica.

Figura $6 \quad 0$ dente 12 extraído e visualizado. Observe a 52 integridade da raiz com o ligamento periodontal intacto e sem toque ou manuseio sobre este.

Figura 7 Reposição do dente no alvéolo com extrusão de aproximadamente $3 \mathrm{~mm}$. Observe o aparato para apoio incisal do dente tracionado, fixado ao dente vizinho com resina composta.

Figura $8 \quad$ Animal mantido $\infty \mathrm{m}$ o colar Elizabetano adaptado para evitar o trauma físico pela aplicação das patas dianteiras nas primeiras semanas.

Figura 09 Perímetro de raiz dividido em quatro partes para graduação da intensidade dos eventos de reabsorção radicular externa. 
Figura 10

Extrusão Cirúrgica, 7 dias, 1/3 coronal. H.E. 4 X. Largura do ligamento periodontal. irregular, sinal de ruptura na porção intermediária e manutenção da camada cementária.

Figura 11 Extrusão Cirúrgica, 7 dias, 1/3 coronal. H.E. 10 X. Ligamento periodontal íntegro junto à superfície radicular, ruptura na sua porção intermediária e presença de infiltrado inflamatório crônico.

Figura 12 Extrusão Cirúrgica, 7 dias, 1/3 coronal. H.E. 40 X. Ligamento periodontal íntegro junto à superfície radicular, ruptura na sua porção intermediária, intensa vascularização e presença de infiltrado inflamatório intenso.

Figura 13 Extrusão Cirúrgica, 7 dias, 1/3 coronal. H.E. 40 X. Aparência normal do ligamento periodontal denso, proliferação celular e vascular, e osteoclasia.

Figura 14 Extrusão Cirúrgica, 7 dias, 1/3 médio. H.E. 10 X. Ligamento periodontal íntegro junto à superfície radicular, ruptura na sua porção intermediária e presença de infiltrado inflamatório e atividade de reabsorção óssea.

Figura 15 Extrusão Cirúrgica, 7 dias, 1/3 apical. H.E. 4 X. Irregularidade da largura do ligamento periodontal, sinais de ruptura na sua porção intermediária e também do seu restabelecimento.

Figura 16

Extrusão Cirúrgica, 7 dias, 1/3 apical. H.E. 40 X. Solução de continuidade da camada cementária pela reabsorção de superfície ativa com a presença de células gigantes multinucleadas.

Figura 17 Extrusão Cirúrgica, 7 dias, 1/3 apical. H.E. 40 X. Ligamento periodontal colagenoso e altamente celular, presença de restos epiteliais de Malassez.

Figura 18 Extrusão Cirúrgica, 7 dias, 1/3 apical. H.E. 40 X. Superfície óssea com atividade de reabsorção e a presença de osteoclastos. 
Figura 19

Figura 20

Figura 21

Figura 23

Figura 24

Figura 25

Figura 26

Figura 27

Figura 28
Extrusão Ortodôntica, 7 dias, 1/3 coronal. H.E.

92

40X. Ligamento periodontal normalmente estruturado, discreta alteração na porção intermediária.

Extrusão Ortodôntica, 7 dias, 1/3 médio. H.E.10 X. Ligamento periodontal denso colagenoso e atividade de remodelamento ósseo.

Extrusão Ortodôntica, 7 dias, 1/3 apical. H.E.10 X.

Superfície óssea em remodelação com a presença de células gigantes multinucleadas.

Extrusão Cirúrgica, 14 dias, $1 / 3$ coronal. H.E.10 X. Presença da ruptura do ligamento periodontal na sua porção intermediária e presença de infiltrado inflamatório crônico.

Extrusão Cirúrgica, 14 dias, $1 / 3$ coronal. H.E.40 X. Reabsorção inflamatória ativa na superfície do cemento. Intenso infiltrado inflamatório.

Extrusão Cirúrgica, 14 dias, 1/3 coronal. H.E.40 X. Reabsorção de superfície ativa no cemento, célula gigante multinucleada na cavidade de reabsorção e ligamento denso colagenoso.

Extrusão Cirúrgica, 14 dias, 1/3 coronal. H.E.40 X. Proliferação de fibroblastos e de vasos sanguíneos na porção intermediária do ligamento periodontal.

Extrusão Cirúrgica, 14 dias, 1/3 médio. H.E. $10 \mathrm{X}$. Largura irregular do ligamento periodontal, ilustrando uma área de proximidade maior entre o dente e osso alveolar.

Extrusão Cirúrgica, 14 dias, 1/3 médio. H.E. 40 X. Atividade de reabsorção óssea no local de diminuição da largura do ligamento periodontal.

Extrusão Cirúrgica, 14 dias, 1/3 apical. H.E. 4 X. Aparência do ligamento periodontal restabelecido na sua maioria, a sua largura não é uniforme. 
Figura 29

Extrusão Cirúrgica, 14 dias, 1/3 apical. H.E. 10 X.

Ligamento periodontal restabelecido com proliferação de fibroblastos e presença de fibras de Sharpey.

Figura 30 Extrusão Ortodôntica, 14 dias, 1/3 coronal. H.E. $40 \mathrm{X}$. Ligamento periodontal denso e colagenoso, observa-se ainda a presença de célula epitelial de Malassez junto àraiz.

Figura $31 \quad$ Extrusão Ortodôntica, 14 dias, 1/3 apical. H.E. 40 X. Remodelação fisiológica do osso aveolar, ligamento periodontal denso fibroso e cemento íntegro.

Figura $32 \quad$ Extrusão Cirúrgica, 45 dias, 1/3 coronal. H.E. 40 X. Reparação da reabsorção inflamatória no cemento, presença de novo cemento e tecido conjuntivo pouco denso e infiltrado inflamatório crônico.

Figura 33 Extrusão Cirúrgica, 45 dias, 1/3 coronal. H.E. 40 X. Reparação da reabsorção de superfície no cemento e tecido conjuntivo normal ao redor.

Figura $34 \quad$ Extrusão Cirúrgica, 45 dias, 1/3 médio. H.E. 40 X. Ligamento periodontal desorganizado na área da reparação de reabsorção de superfície na dentina.

Figura $35 \quad$ Extrusão Cirúrgica, 45 dias, 1/3 médio. H.E. 10 X. Ancilose de cemento e osso alveolar e pequena área com reabsorção óssea no mesmo local.

Figura 36

Extrusão Cirúrgica, 45 dias, 1/3 apical. H.E. 40 X. Reparação da reabsorção de superfície no cemento, presença de novo cemento e tecido conjuntivo pouco denso e desorganizado.

Figura 37 Extrusão Ortodôntica, 45 dias, 1/3 coronal. H.E. $40 \mathrm{X}$. Ligamento periodontal estruturado com densidade de colágeno e de fibroblastos, presença de restos epiteliais de Malassez.

Figura 38 Extrusão Ortodôntica, 45 dias, 1/3 coronal. H.E. 40 X. Reparação da reabsorção de superfície no cemento e ligamento pouco denso na região. 
Figura 39

Figura 40

Figura 41

Figura 42

Figura 43

Figura 44

Figura 45

Figura 46

Figura 47

Extrusão Ortodôntica, 45 dias, 1/3 médio. H.E. 40 X. Reparação da reabsorção de superfície na dentina, formação de cemento novo e tecido conjuntivo pouco denso.

Extrusão Cirúrgica, 90 dias, 1/3 coronal. H.E.10 X. Extensa reparação da reabsorção de superfície na dentina com fibras colágenas paralelas e presença de ligamento periodontal restabelecido no outro lado.

Extrusão Cirúrgica, 90 dias, 1/3 médio. H.E. 40 X. Reparação da reabsorção de superfície no cemento e dentina por deposição de novo cemento, evidenciando tecido conjuntivo normal ao redor, porém ainda não funcional.

Extrusão Cirúrgica, 90 dias, 1/3 apical. H.E. 40 X.

Reparação da reabsorção inflamatória na dentina, ligamento não funcional e presença de infiltrado inflamatório crônico.

Extrusão Ortodôntica, 90 dias, 1/3 coronal. H.E. 40 X. Reparação da reabsorção de superfície no cemento, observa-se a inserção de fibras de Sharpey.

Extrusão Ortodôntica, 90 dias, 1/3 médio. H.E.

10 X. Reparação da reabsorção de superfície, presença de novo cemento e ligamento periodontal estruturado.

98

Extrusão Ortodôntica, 90 dias, 1/3 médio. H.E. 98 40 X. Reparação da reabsorção de superfície no cemento e tecido conjuntivo denso fibroso.

Extrusão Ortodôntica, 90 dias, 1/3 apical. H.E. $40 \mathrm{X}$. Ligamento periodontal, cemento e osso alveolar estruturados normalmente, presença de restos epiteliais de Malassez.

Extrusão Cirúrgica, 120 dias, 1/3 coronal. H.E. 10 X. Reparação da reabsorção de superfície no cemento e dentina, observa-se a disposição paralela de fibras. 
Figura 48

Figura 49

Figura 50

Figura 51

Figura 52

Figura 54

Figura 55

Figura 56
Extrusão Cirúrgica, 120 dias, 1/3 médio. H.E. $40 \mathrm{X}$. Ancilose e reparação da reabsorção de superfície na dentina.

Extrusão Cirúrgica, 120 dias, 1/3 apical. H.E. 40 X. Reparação da reabsorção de superfície, presença de novo cemento e ligamento periodontal não funcional.

Extrusão Ortodôntica, 120 dias, 1/3 coronal. H.E. 40 X. Reparação da reabsorção de superfície na dentina, ligamento não funcional.

Extrusão Ortodôntica, 120 dias, 1/3 médio. H.E. 40 X. Reparação da reabsorção de superfície na dentina e ligamento periodontal organizado. A reparação com característica de osteocemento.

Extrusão Ortodôntica, 120 dias, 1/3 apical. H.E. $40 \mathrm{X}$. Cemento e ligamento periodontal organizados, colágeno denso e restos epiteliais de Malassez.

Extrusão Cirúrgica, 180 dias, $1 / 3$ coronal. H.E. 40 X. Reparação da reabsorção de superfície no cemento e tecido conjuntivo denso fibroso. A reparação com característica de osteocemento.

Extrusão Cirúrgica, 180 dias, 1/3 médio. H.E. 40 X. Reparação da reabsorção de superfície na dentina, ligamento periodontal denso funcional.

Extrusão Cirúrgica, 180 dias, $1 / 3$ apical. H.E. 40 X. Reparação da reabsorção de superfície na dentina, observa-se a inserção de fibras de Sharpey no novo cemento.

Extrusão Cirúrgica, 180 dias, 1/3 apical. H.E. 40 X. Reparação da reabsorção inflamatória, tecido conjuntivo fibroso junto ao cemento neoformado e presença do infiltrado inflamatório crônico. 
Figura 57

Extrusão Cirúrgica, 180 dias, 1/3 apical. H.E.

$40 \mathrm{X}$. Ligamento periodontal estruturado com fibras de Sharpey.

Figura 58 Extrusão Ortodôntica, 180 dias, 1/3 coronal. H.E. 102 10 X. Reparação da reabsorção de superfície no cemento e ligamento periodontal organizado.

Figura 59 Extrusão Ortodôntica, 180 dias, 1/3 médio. H.E. 102 40 X. Reparação da reabsorção de superfície no cemento e dentina, ligamento periodontal denso funcional.

Figura 60 Extrusão Ortodôntica, 180 dias, 1/3 apical. H.E. 40 X. Reparação da reabsorção de superfície na dentina, observa-se um ligamento organizado.

Figura 61 Extrusão Ortodôntica, 180 dias, 1/3 apical. H.E. 102 $40 \mathrm{X}$. Ligamento periodontal estruturado com fibras de Sharpey. 


\section{LISTA DE ABREVIATURAS}

$\begin{array}{ll}\text { RSA 1 } & \text { Reabsorção ativa de superficie grau 1 } \\ \text { RSA 2 } & \text { Reabsorção ativa de superficie grau 2 } \\ \text { RSA 3 } & \text { Reabsorção ativa de superficie grau 3 } \\ \text { RRS 1 } & \text { Reparação da reabsorção de superfície grau 1 } \\ \text { RRS 2 } & \text { Reparação da reabsorção de superfície grau 2 } \\ \text { RRS 3 } & \text { Reparação da reabsorção de superfície grau 3 } \\ \text { RIA 1 } & \text { Reabsorção ativa inflamatória grau 1 } \\ \text { RIA 2 } & \text { Reabsorção ativa inflamatória grau 2 } \\ \text { RIA 3 } & \text { Reabsorção ativa inflamatória grau 3 } \\ \text { RRI 1 } & \text { Reparação da reabsorção inflamatória grau 1 } \\ \text { RRI 2 } & \text { Reparação da reabsorção inflamatória grau 2 } \\ \text { RRI 3 } & \text { Reparação da reabsorção inflamatória grau 3 } \\ \text { RPS 1 } & \text { Reabsorção por substituição grau 1 } \\ \text { RPS 2 } & \text { Reabsorção por substituição grau 2 } \\ \text { RPS 3 } & \text { Reabsorção por substituição grau 3 }\end{array}$




\section{RESUMO}

A invasão das distâncias biológicas do periodonto marginal por fraturas dentárias, cáries, preparos protéticos subgengivais e trepanações, desencadeiam sérias conseqüências sobre o periodonto.

Usualmente para a recuperação da condição biológica em dentes com o comprometimento destas distâncias, diferentes abordagens terapêuticas periodontais são utilizadas, tais como retalho posicionado apicalmente com osteotomia, extrusão ortodôntica e mais recentemente a extrusão cirúrgica.

O princípio básico da extrusão cirúrgica é o mesmo da extrusão ortodôntica, movimentar a raiz para uma posição mais coronal, ou seja, deslocar a região cervical comprometida do dente para uma posição supragengival. Sendo assim, este tratamento seria indicado apenas em dentes com ápice completamente formado e com o remanescente intra-alveolar longo o suficiente para suportar uma coroa protética.

A extrusão cirúrgica foi relatada como uma solução eficaz para fraturas subgengivais de dentes anteriores em jovens e em situações de destruição da coroa dentária por cárie, nas quais os dentes receberam diferente tipos de restauração $43,44,45,46,47,48,79,80$.

Apesar da efetividade clínica e de algumas vantagens sobre a extrusão ortodôntica, a extrusão cirúrgica tem sido realizada baseando-se na reparação após reimplante dentário imediato. As considerações da reparação deste procedimento extrapolariam para a extrusão cirúrgica devido as semelhanças clínicas. 
Tanto a extrusão cirúrgica como a ortodôntica com movimento rápido não são descritos na literatura com considerações histológicas durante o processo de reparação. Por isso, este estudo tem o objetivo de avaliar comparativamente os dentes que foram submetidos aos procedimentos de extrusão ortodôntica rápida e extrusão cirúrgica, em períodos determinados.

Para o estudo foram selecionados 18 cães machos adultos divididos em 6 grupos de 3 animais cada. Em cada animal foram aplicados dois procedimentos, a extrusão ortodôntica como lado controle e a extrusão cirúrgica como lado experimental. Para tanto foram escolhidos os dentes incisivos laterais superiores e antes do início da extrusão foram realizados tratamentos endodônticos nos dentes.

No lado controle, a tração foi rápida usando uma força acima dos níveis considerados fisiológico. O movimento dentário foi promovido pela ativação do elástico em cadeia que ligou entre o pino intra-canal e a ancoragem transversal, ambos confeccionados com fio de aço $0,7 \mathrm{~mm}$. A tração coronal foi de aproximadamente $3 \mathrm{~mm}$ e o tempo médio variou de 3 a 4 semanas.

No lado experimental, a extrusão cirúrgica foi pela avulsão cuidadosa do dente e a reposição do mesmo no alvéolo numa posição aproximadamente $3 \mathrm{~mm}$ mais coronal. A raiz extruída foi estabilizada somente por sutura interproximal e um apoio incisal com um fio de aço ligado ao dente vizinho para prevenir esfoliação no período inicial.

Os animais foram sacrificados de modo a obter amostras dos períodos de 7, 14, 45, 90, 120 e 180 dias pós-operatórios. As peças removidas em bloco, após a fixação em formol tamponado a 10 \% e descalcificação, tiveram 
processamentos laboratoriais de rotina e cortes transversais nos terços coronal, médio e apical, e as lâminas obtidas foram coradas pela técnica de hematoxilina-eosina e avaliadas histologicamente.

Os resultados mostraram a importância da manutenção do ligamento periodontal e superfície do cemento vital e íntegro para prevenir reabsorção radicular. A ruptura do ligamento periodontal promoveu a deflagração da atividade de reabsorção radicular que foi observada nos períodos iniciais de 7 e 14 dias do grupo experimental. As amostras dos períodos mais avançados mostraram a reparação extensa das reabsorções em todos os terços avaliados, principalmente a de reabsorção de superfície. É importante salientar que todas as cavidades de reabsorção foram reparadas sendo inicialmente não funcional, porém nas amostras finais mostraram ser funcionais. A ancilose não foi um achado regular como se relata nos estudos de reimplante dentário.

No lado controle, em função da aplicação da força pesada com o objetivo de tração rápida observou-se também algumas alterações na superfície radicular. A atividade de reabsorção não foi vista, porém nos períodos mais avançados mostraram áreas de reparação da reabsorção de superfície, demonstrando assim, o efeito lesivo da tração rápida. Mesmo assim, com semelhança ao lado experimental, todas as reabsorções de superfície foram reparadas funcionalmente nos períodos avançados.

É importante salientar que apesar das reabsorções radiculares associadas ao trauma mecânico cirúrgico e ortodôntico, a reparação das mesmas com restabelecimento funcional do ligamento periodontal foi alcançada, porém não se pode afirmar regeneração das estruturas. 
Frente aos resultados obtidos, há de se convir que os procedimentos de extrusão dentária, sejam cirúrgicos ou ortodônticos, levam à obtenção de um processo biológico satisfatório com aplicabilidade clínica sugerida. 


\section{INTRODUÇÃO}




\section{1 - INTRODUÇÃO}

As distâncias biológicas definidas por GARGIULO, WENTZ \& ORBAN $^{33}$, quando invadidas por fraturas, cáries, preparos protéticos subgengivais e trepanações, desencadeiam sérias conseqüências sobre o periodonto e o restabelecimento da homeostasia está na dependência da reconstituição destas distâncias. A recuperação de extensão saudável e adequada da superfície radicular entre a margem gengival e a crista óssea marginal proporciona a nova formação de fibras de Sharpey (área de inserção conjuntiva) e adesão do epitélio juncional, reformando assim as distâncias biológicas consideradas por DE WAAL \& CASTELLUCC ${ }^{32}$ como "sagradas" para a intervenção restauradora.

Usualmente para a recuperação da condição biológica em dentes com invasão destas distâncias têm sido consideradas necessárias abordagens terapêuticas periodontais cirúrgicas ou ortodônticas (DE PAOLI, NEVINS \& CAPPETTA $^{31}$ ).

O retalho posicionado apicalmente com osteotomia e/ou osteoplastia para obter arquitetura óssea fisiológica descrito por $\mathrm{SCHLUGER}^{73} \mathrm{e}$ OCHSENBEIN \& ROSS ${ }^{64}$ promove o restabelecimento das distâncias biológicas num nível mais apical. Apesar dos resultados previsíveis e seguros deste procedimento cirúrgico, há que se ter cautela em situações que apresentam exigências estéticas, porque promove a perda de inserção periodontal pela osteotomia, além da necessidade desta intervenção se estender para os dentes adjacentes com o objetivo de restabelecer a arquitetura fisiológica do periodonto. 
O movimento dentário em direção coronal através da aplicação da força leve e contínua para promover mudanças nos tecidos gengival e osso alveolar foi sugerido por HEITHERSAY ${ }^{39}$; INGBER ${ }^{40}$; PASSANEZI et al. ${ }^{67}$ como alternativa para o tratamento não cirúrgico do dente com invasão das distâncias biológicas. Visto que os procedimentos ressectivos são considerados muitas vezes agressivos, pois promovem pela osteotomia a perda de inserção e o comprometimento de estética ${ }^{40,41,52}$. Por esta razão, a extrusão ortodôntica tem sido uma opção importante na terapêutica periodontal, considerada conservadora, pela manutenção da inserção periodontal. Para isso, tem se sugerido movimento lento. Sabe-se que a força de tração lenta considerada ótima de 25 a $30 \mathrm{~g}$ é recomendada para a movimentação dentária compatível fisiologicamente para a formação das estruturas periodontais (STROSTER) ${ }^{78}$. Por outro lado, há indicação de tração rápida o que proporciona clinicamente um resultado mais rápido com o objetivo de extruir apenas o dente em questão, e que apresenta reações periodontais distintas da movimentação lenta (NEDER) ${ }^{63}$.

Recentemente uma outra modalidade terapêutica cirúrgica foi descrita por TEGSJÖ, VALERIUS-OLSON \& OLGART ${ }^{80}$ para situações de fraturas corono-radiculares de dentes anteriores superiores em jovens que sofreram traumatismo, tendo sido denominada inicialmente transplante dentário intra-alveolar e mais tarde extrusão cirúrgica por $\mathrm{KHANBERG}^{44}$, quando passos da técnica convencional de exodontia foram aplicados, porém, como resultado final o dente foi mantido e posicionado coronalmente no alvéolo. Segundo TEGSJÖ et al. ${ }^{79}$, nesta modalidade cirúrgica a cicatrização do dente transplantado intra-alveolarmente se baseia no comportamento biológico de 
reimplante dentário em casos de avulsão dos mesmos com a vantagem de permitir a visualização da raiz, melhorando assim o posicionamento terapêutico em situações onde há sinais de fratura radicular, o que não é alcançado pela extrusão ortodôntica. Segundo os autores, o método tradicional para eliminação de lesões buco-dentárias, a exodontia, ganha novo espaço para a aplicação de um objetivo totalmente oposto que lhe fora atribuído na Odontologia.

O princípio básico da extrusão cirúrgica é o mesmo da extrusão ortodôntica, movimentar a raiz para uma posição coronal, ou seja, deslocar a região cervical comprometida do dente para uma posição supragengival. Deste modo, este tratamento pode ser indicado em dentes com remanescente intraalveolar longo o suficiente para suportar uma coroa protética retida por núcleo.

A extrusão cirúrgica tem sido solução eficaz para fraturas dentárias subgengivais, como também em situação de destruição da coroa dentária por cáries $^{43,44,45,46,47,48,79,80}$. Resultado clínico-radiográfico importante foi relatado por $\mathrm{KHANBERG}^{45}$ em estudo longitudinal de 10 anos em dentes que foram submetidos ao procedimento de extrusão cirúrgica: em todos os dentes extruídos que receberam diferentes tipos de restaurações, não foram observados sinais clínicos ou radiográficos de alterações patológicas que pudessem comprometer o procedimento.

A indicação inicial da terapêutica da extrusão cirúrgica foi estendida para situações de destruição completa da coroa dentária por cáries em dentes permanentes de adultos e com invasão das distâncias biológicas. KIM, TRAMONTINA \& PASSANEZI ${ }^{47}$; KIM et al. ${ }^{48}$; MAGINI et al. ${ }^{57}$. apresentaram as vantagens desta técnica cirúrgica. Quando comparada com a extrusão 
ortodôntica rápida, a resolução pode ser considerada mais rápida e simples, diminuindo o tempo operatório e o próprio tempo total do tratamento até a resolução definitiva na restauração da coroa dentária; porém, quando comparada com o procedimento cirúrgico de retalho posicionado apicalmente com osteotomia, o que aumenta consequentemente a coroa clínica, pode-se dizer que o procedimento de extrusão cirúrgica é conservador, porque é possível manter a arquitetura gengival e óssea, assegurando assim as características de inserção e estética para uma futura restauração da coroa dentária.

As considerações sobre a cicatrização do ligamento periodontal após extrusão cirúrgica têm refletido situações clínicas semelhantes ao reimplante de dentes avulsionados por traumatismo. Há muito tempo o reimplante dentário tem sido objeto de discussão na comunidade odontológica e desde então, muitas hipóteses foram levantadas para especular o processo de cicatrização do dente reimplantado no alvéolo. Décadas de estudos e muito esforço levaram para a compreensão atual. Portanto, nos dias atuais não existe dúvida sobre a importância e a função do periodonto na cicatrização do dente reimplantado. Há consenso sobre a manutenção da vitalidade do ligamento periodontal e da superfície cementária para restabelecer um periodonto normal e funcional após a reimplantação dentária, levando-se em consideração, a importância da manutenção destas para a prevenção da ancilose $e^{1,5,6,10,12,18,56,82}$. Ainda, a importância da presença dos restos epiteliais de Malassez foi sugerida na manutenção do espaço fisiológico do ligamento periodontal ${ }^{55,56,75}$.

Trauma mecânico durante a exodontia pode provocar alterações celulares no ligamento periodontal pelo esmagamento deste junto àraiz, porém a 
extensão deste dano ainda não está estabelecida. Por outro lado, uma possível compreensão da reabsorção radicular pode advir do exame das zonas de trauma no ligamento periodontal em dentes reimplantados antes do início da reabsorção (i.e. dentro de 2 semanas após o reimplante dentário) e comparar os achados com o padrão da reabsorção radicular em períodos posteriores em dentes reimplantados similarmente. Segundo ANDREASEN ${ }^{10}$, o período de observação variando entre 2 a 8 semanas parece ser ótimo para registrar todos os tipos de reabsorção radicular através da análise histológica em dentes reimplantados.

Como o procedimento de extrusão cirúrgica é uma variação intencional do reimplante dentário, tende a se extrapolar o resultado deste. Todavia, é necessário que se faça a própria avaliação da cicatrização. Sendo assim, o objetivo do estudo foi obter resultados histológicos de dentes submetidos ao procedimento de extrusão cirúrgica em cães, comparativamente a dentes que foram submetidos àextrusão ortodôntica rápida. 
2. REVISTA DA LITERATURA 


\section{2 - REVISTA DA LITERATURA}

O envolvimento das distâncias biológicas por fratura coronoradicular subgengival dos dentes têm resoluções terapêuticas com o objetivo de promover exposição cervical para a restauração anatômica e funcional do periodonto. Deste modo, alguns procedimentos periodontais com objetivo de restabelecer as distâncias biológicas são apresentados na literatura, tais como: procedimento de retalho com ressecção óssea, movimento de extrusão ortodôntica e transplante dentário intra-alveolar ou extrusão cirúrgica.

O primeiro apresenta a resolução imediata, eficaz e previsível, porém, provoca a perda de inserção, aumentando a coroa clínica, apresentando restrições em áreas estéticas. Por sua vez, a extrusão ortodôntica foi proposta tanto para solucionar defeitos periodontais, como também, em fraturas cervicais subgengivais de dentes anteriores para reestruturar os tecidos periodontais. Por último, a extrusão cirúrgica apresenta propósito semelhante ao procedimento anterior, mas promove a tração dentária imediata com resolução mais rápida.

Com a finalidade de direcionar e facilitar a compreensão dos procedimentos envolvidos será apresentada a revisão de literatura para aqueles trabalhos pertinentes aos parâmetros propostos neste estudo. 


\subsection{Reimplante dentário}

A extrusão cirúrgica apresenta características clínicas semelhantes ao procedimento de reimplante dentário imediato e por isso inicialmente a sua cicatrização foi baseada nos relatos de estudos experimentais destes.

Reimplante e transplante dentário têm uma longa história, praticados inicialmente com empirismo foram levados ao fracasso devido æ̀ complicações no processo de cicatrização do periodonto. As investigações experimentais iniciaram com HUNTER e YOUNGER (apud LÖE \& WAERHAUG ${ }^{56}$ ) há mais de 200 anos, mas somente com a elucidação recente sobre a natureza da etiologia e patologia da reabsorção dentária e processo de cicatrização do periodonto tornou-se possível a aplicação clínica segura. 0 conhecimento e valorização das estruturas periodontais proporcionou um prognóstico mais favorável após a reimplantação dentária e por conseguinte a extrusão dentária cirúrgica. Ocorrendo o mesmo para a extrusão dentária ortodôntica, na qual a movimentação do dente está dependente dos fenômenos celulares e vasculares que ocorrem no periodonto.

Segundo HAMMER $^{38}$ em 1955, o papel do ligamento periodontal na reimplantação dentária é similar ao papel do periósteo no transplante ósseo. De acordo com as investigações, a sobrevivência de um dente reimplantado é proporcional à quantidade de ligamento periodontal preservado. Um dente reimplantado sem este, pode até obter fixação, mas o resultado final será invariavelmente uma substituição completa da raiz pelo osso até a perda do dente. Após 4 dias do reimplante ambas as estruturas, osso e dente, preservaram o ligamento periodontal conectando-os por uma ciatrização recente. 
Os requisitos funcionais do ligamento periodontal estão dependentes na presença das fibras de Sharpey e isto ocorreu aproximadamente após 4 a 6 semanas após o reimplante dentário restaurando perfeitamente a estrutura periodontal.

LÖE \& WAERHAUG ${ }^{56}$ em 1961, estudaram reimplante experimental em animais. Cinquenta e oito dentes foram reimplantados, dos quais treze sem o ligamento periodontal, quinze mantidos secos com períodos variando de 15 minutos a 2 horas antes da reimplantação e 30 reimplantados imediatamente após a extração. O período de observação variou entre 8 dias e 33 meses. Nos dentes reimplantados sem o ligamento periodontal não ocorreu a formação das estruturas de inserção. Primeiramente, o espaço foi preenchido pelo tecido mole e depois pelo osso alveolar. A estabilização pela ancilose foi vista em 30 dias. Em dentes mantidos secos, o ligamento periodontal estava alterado e a sua vitalidade variou conforme o período de manutenção fora do alvéolo. E em dentes reimplantados com o ligamento periodontal vitalizado, houve a manutenção normal sem nenhuma ancilose. Segundo os autores, o sucesso ou falha no reimplante dentário parece depender diretamente da presença ou ausência do ligamento periodontal vital. Ainda assim, levantaram a hipótese da participação das células dos restos epiteliais de Malassez que podem exercer um papel importante na manutenção do espaço do ligamento periodontal evitando-se a ancilose.

Uma classificação da reabsorção radicular foi apresentada por ANDREASEN \& HJORTING-HANSEN ${ }^{17}$ em 1966. Basicamente 3 tipos de reabsorções seriam encontradas após a reimplantação de dentes avulsionados: 
reabsorção de superfície, reabsorção inflamatória e reabsorção por substituição. A reabsorção de superfície seria o resultado de uma injúria traumática da superfície da raiz, causando uma pequena ruptura do cemento com a exposição da dentina subjacente, a qual se repararia espontaneamente pela deposição do cemento. A reabsorção inflamatória apresentaria sinais histológicos de áreas com reabsorção no cemento e na dentina, como também, as mudanças inflamatórias dos tecidos periodontais adjacentes. Tecido de granulação reacional seria formado, o qual conteria linfócitos, plasmócitos e leucócitos polimorfonucleares abundantes. Segundo os autores, acredita-se que a inflamação pode ser estimulada também pelos produtos tóxicos oriundos da polpa residual necrótica ou pelo selamento ineficaz do canal radicular seguido por re-infecção bacteriana, pois, bactérias tem sido notados freqüentemente no interior do túbulo dentinário de dentes reimplantados com reabsorção inflamatória. Em outros casos, osteoclastos tem sido observados em algumas lacunas produzidas por um processo de reabsorção severa. A reabsorção por substituição pode preceder a ancilose, mas não necessariamente. De início, imediatamente após a reimplantação, o tecido de granulação se formaria a partir do coágulo sanguíneo e seria substituído na seqüência por osso alveolar trabeculado. A ancilose dentária então, se submeteria ao ciclo de remodelação óssea normal e a raiz seria substituída progressivamente. As células envolvidas neste processo seriam os osteoclastos normais, as quais seriam incapaz de reconhecer cemento radicular e dentina atacando-os como se fosse osso, e os osteoblastos promoveriam o reparo ósseo secundariamente. 
Segundo ANDERSON, SHARAV \& MASSLER ${ }^{1}$ em 1968, estudando a reinserção periodontal após o reimplante dentário experimental em animais, observaram que o fator mais importante para o grau de sucesso no reimplante dentário parece ser o estágio de desenvolvimento do dente relacionado a formação radicular. Os dentes mais jovens exibiram significativamente menos patologias do que os dentes mais maduros após o reimplante. Um outro dado importante foi o tempo decorrido entre a extração dentária e o reimplante do mesmo. As diferenças nas condições e local do periodonto, tais como suprimento sanguíneo e trauma associado a extração também podem contribuir.

MASSLER ${ }^{58}$ em 1974, analisando vários estudos experimentais em animais e humanos, relatou dados documentados que possam substituir as afirmações empíricas do passado. Na cicatrização após o reimplante dentário pode se observar readaptação epitelial em 1 semana e reinserção do ligamento periodontal em 2 a 4 semanas (fibras transeptais em 2 semanas, fibras oblíquas e apicais em 3 semanas). Embora a reabsorção radicular e o reparo possam iniciar mais cedo, não são visíveis em radiografia antes de 4 a 6 semanas. A reabsorção reparativa que é muito pequena e usualmente vista perto da área cervical e sendo reparada por novas fibras do ligamento periodontal ocorre em reimplante imediato, enquanto que a reabsorção progressiva e destrutiva é muito grande e aparece cedo próximo do ápice radicular, especialmente se o cemento sobre a raiz foi eliminado. É observado freqüentemente em reimplante tardio e a ancilose ocorre com morte celular de cementoblastos.

ANDREASEN ${ }^{5}$ em 1975 estudou o efeito da esplintagem sobre a cicatrização periodontal após o reimplante dentário em vinte e um macacos, 
sendo que 2 incisivos superiores foram extraídos em cada animal e os dentes receberam tratamento endodôntico extra-bucalmente. Um primeiro grupo dos dentes foi reimplantado após 18 minutos e o segundo após 120 minutos, e ainda, dos vinte e um animais, oito receberam esplintagem por 6 semanas e outros 6 animais por 2 semanas, e o restante do grupo ou seja, 7 animais, não receberam qualquer contenção. A avaliação histológica foi realizada após 8 semanas e usou-se parâmetros como: reabsorção de superfície, reabsorção inflamatória, reabsorção por substituição, migração do epitélio juncional, mudanças inflamatórias periapicais e extensão da necrose pulpar. Todos os dentes reimplantados após 120 minutos mostraram extensa ancilose, independentemente da esplintagem. No grupo de dentes que foram reimplantados em 18 minutos, a freqüência e extensão da reabsorção por substituição foi significativamente menor nos dentes não esplintados. Nenhuma mudança significativa foi encontrada entre outros parâmetros histológicos utilizados. Sendo assim, o autor concluiu que a esplintagem não melhorou a cicatrização periodontal após o reimplante dentário e aparentemente exerceu um efeito danoso sobre o periodonto.

No mesmo ano, NASJLETI et al. ${ }^{60}$ estudaram a dinâmica das mudanças teciduais durante a cicatrização após a reimplantação de incisivos superiores em macacos. O estudo revelou a ocorrência da nova inserção logo após o reimplante dentário. Tecidos epiteliais iniciaram a proliferação imediatamente após o reimplante alcançando o pico em 3 dias. Após 7 dias um novo epitélio juncional foi restabelecido. A proliferação do tecido conjuntivo alcançou o pico em 7 dias e iniciou principalmente no nível supra-ósseo e nos 
espaços medulares do tecido ósseo. A interface do ligamento periodontal não foi detectável após 7 dias, sendo reposto por um tecido conjuntivo jovem, o qual restabeleceu a continuidade do ligamento periodontal e tecido conjuntivo. A orientação e a maturação das fibras não foram observadas antes de 4 meses após o reimplante. Mudanças em direção a reabsorção radicular e ancilose foram vistos precocemente em 14 dias após o reimplante.

NASJLETI, CAFFESSE \& CASTELLI ${ }^{61}$ em 1978, avaliaram a resposta histológica dos dentes reimplantados com e sem tratamento endodôntico. Os autores não conseguiram observar diferenças significativas entre os dentes reimplantados com e sem tratamento endodôntico prévio numa análise histológica da cicatrização do ligamento periodontal em períodos que variaram de 5 dias a 3 meses.

CASTELLI et al. ${ }^{28}$ em 1980, avaliaram o padrão de revascularização do ligamento periodontal e a modificação da sua vascularidade devido a reabsorção radicular, ancilose dentoalveolar e processo periapical em dentes reimplantados experimentalmente. A atividade reparativa precoce foi vista nas regiões apical e cervical ocorrendo proliferação dos vasos que se misturaram com as células reparativas e fibras colágenas ininterruptas. Estas áreas corresponderam ao maior suprimento vascular após o reimplante dentário. $\mathrm{O}$ terço médio do ligamento periodontal no entanto, mostrou a falta ou ausência de células reparativas como resultado da demora na revascularização promovendo assim, a degeneração hialina. Reabsorção radicular, ancilose dentoalveolar e processo periapical dependeram tanto da especificidade do ligamento periodontal como do padrão do suprimento vascular do dente reimplantado. 
No mesmo ano, ANDREASEN ${ }^{6}$ registrou a cicatrização periodontal e pulpar histometricamente em diferentes períodos de observação após a reimplantação de dentes incisivos em macacos. Os dentes foram extraídos e então reimplantados imediatamente ou após 18 minutos, e ainda neste grupo os dentes foram mantidos secos durante este período. Os períodos de avaliação clínica de mobilidade e histológica foram 1, 2, 3, 4 e 8 semanas e os parâmetros utilizados foram: cicatrização do ligamento periodontal, reabsorção de superfície, reabsorção inflamatória, reabsorção por substituição e o grau de vitalidade pulpar. A cicatrização do ligamento periodontal e o restabelecimento da mobilidade fisiológica dos dentes ocorreram entre 2 a 4 semanas. A reabsorção de superfície foi vista em ambos os grupos e em número reduzido após 1 semana, mas após 2 semanas a reabsorção inflamatória e reabsorção por substituição aumentou significativamente no segundo grupo e a sua freqüência aumentou discretamente após 4 a 8 semanas. Após 8 semanas o aumento da reabsorção inflamatória continuou em ambos os grupos, no entanto, a reabsorção por substituição desapareceu por completo no primeiro grupo.

Ainda no mesmo ano, ANDREASEN ${ }^{8}$ analisou a topografia da reabsorção de superfície e reabsorção inflamatória. O estudo experimental compreendeu 2 grupos: no primeiro, os dentes foram reimplantados com a manutenção de 18 minutos fora do alvéolo e no segundo, 120 minutos. Os resultados mostraram a mesma freqüência para as reabsorções nas superfícies convexas vestibulares e ling uais devido ao dano mecânico pela apreensão com a pinça extratora. 
Ainda, em uma outra avaliação dentro das mesmas condições experimentais, ANDREASEN ${ }^{9}$ avaliou a patogênese e topografia da reabsorção por substituição após o reimplante experimental em macacos. A ancilose fora significativamente maior nas faces convexas vestibular e lingual do que nas faces côncavas e planas proximais, resposta esta devido ao traumatismo durante a exodontia, danificando parte do ligamento periodontal e da superfície radicular. Além disso, as condições de estocagem e período de permanência fora do alvéolo contribuíram na formação de ancilose.

Por sua vez, VAN HASSEL, OSWALD \& HARRINGTON ${ }^{82}$ em 1980 estabeleceram a vitalidade do ligamento periodontal como um fator importante para impedir a reabsorção em dentes reimplantados. Em estudo experimental, os dentes incisivos de macacos foram extraídos para instrumentação mecânica de uma parte da raiz para eliminação do ligamento periodontal e reimplantados. Os resultados mostraram severa reabsorção radicular em locais onde não havia ligamento periodontal.

O efeito da remoção de coágulo do alvéolo antes do reimplante dentário sobre a cicatrização periodontal e pulpar foi estudado por ANDREASEN ${ }^{7}$ em 1980. No lado controle os dentes foram reimplantados sem a retirada do coágulo, enquanto que, no lado experimental os dentes foram reimplantados após a retirada do coágulo usando curetas. $\mathrm{Na}$ avaliação histológica após 8 semanas nenhuma diferença significativa foi encontrada. Baseado nos resultados, o autor sugeriu que a reimplantação de dentes avulsionados deveria ser levado ao alvéolo imediatamente, sem a tentativa de remover o coágulo do seu interior. 
No ano seguinte, ANDREASEN ${ }^{12}$ estudou o efeito da injúria no cemento e ligamento periodontal sobre a cicatrização dos dentes reimplantados experimentalmente em macacos. O grupo experimental variou tanto no tempo de reimplantação de 18 e 120 minutos como também no dano mecânico proposital da superfície radicular pela raspagem e tratamento endodôntico. Concluiurse que independentemente da situação, a presença do ligamento periodontal intacto e viável sobre a superfície da raiz é o fator mais importante para assegurar a cicatrização sem reabsorção radicular.

ANDREASEN \& KRISTERSON ${ }^{20}$ em 1981, produziram experimentalmente exposição da superfície radicular pela remoção do ligamento periodontal e isso levou ao desenvolvimento de diferentes tipos de reabsorções na superfície radicular. No entanto, lesões mecânicas produzidas de $1 \mathrm{~mm}^{2} \mathrm{e}$ $4 \mathrm{~mm}^{2}$ sobre a superfície radicular desenvolveram ancilose transitória no período de 2 a 8 semanas, havendo a reparação completa após este período, enquanto nas lesões envolvendo áreas maiores de $9 \mathrm{~mm}$ e $16 \mathrm{~mm}$ resultaram em ancilose persistente mesmo após o período de 8 semanas. Baseado nos achados, foi pressuposto que, a remoção física do ligamento periodontal promove uma rápida osteogênese local estabelecendo a ancilose. Se esta área se situa próximo ao ligamento periodontal vital, um processo reabsortivo tardio será estabelecido, pelo qual a ancilose será gradualmente reabsorvido. Foi estimado que a extensão deste processo neste experimento era de 1 a 1,5 mm. Concluíram portanto que a proliferação das células do ligamento periodontal intacto e próximo da área danificada pode prevenir ou remover a ancilose. 
No mesmo ano, ANDREASEN $^{10}$ registrou a relação entre o dano celular no ligamento periodontal após o reimplante dentário e desenvolvimento subsequente da reabsorção radicular experimentalmente em macacos. O dano mecânico devido ao procedimento de extração dentária foi registrada e o desenvolvimento da reabsorção radicular relacionada histologicamente. Análises histométricas mostraram as reabsorções de superfície, inflamatória e por substituição que tem relação significativa para as regiões topográficas específicas como convexidade da superfície da raiz, principalmente nas superfícies vestibulares e linguais, as quais sofreram maior dano mecânico durante a exodontia. O grau e a extensão do dano nas células do ligamento periodontal e o número de cementoblatos por unidade de área relacionou-se com as reabsorções radiculares.

O efeito do período de exposição extra alveolar do dente a ser reimplantado e dos meios de conservação deste sobre a cicatrização periodontal e pulpar após o reimplante experimental em macacos, foi estudado por ANDREASEN $^{11}$ em 1981. Os períodos de exposição extra alveolar antes do reimplante foram $0,18,30,60,90$ e 120 minutos. Os meios de conservação dos dentes foram: água, solução salina, saliva ou secagem natural. Os animais foram sacrificados após 8 semanas e examinados histologicamente. Uma relação significativa foi encontrada entre a freqüência da reabsorção radicular, o aumento do tempo extra alveolar e o meio de conservação. A reabsorção de superfície foi encontrada com a mesma freqüência independentemente do tempo de permanência fora do alvéolo. A reabsorção inflamatória foi comum após o meio de secagem e estava relacionada ao período extra alveolar longo, que após 30 
minutos foi proeminente para este tipo de reabsorção. A reabsorção por substituição mostrou uma forte relação com a manutenção por secagem e tornou-se comum após 60 minutos, mas raramente foi encontrado em dentes que mantiveram úmidos fora do alvéolo.

Em um outro estudo, ANDREASEN ${ }^{14}$ em 1981, avaliou o efeito da força oclusal excessiva sobre os dentes reimplantados. O estudo experimental em macacos compreendeu dois grupos controles e dois grupos experimentais. No lado controle, um dente era esplintado e outro não; no lado experimental, um dente era submetido a força oclusal excessiva e o outro a força ortodôntica. $\mathrm{O}$ período extra-alveolar antes da reimplantação dos dentes foi de 120 minutos. 0 fator trauma foi eliminado após 6 semanas e os animais foram sacrificados em 8 semanas para avaliação histológica. $\mathrm{Na}$ análise de espécimes foi encontrado ancilose com a mesma freqüência e extensão em todos os grupos, variando somente nos padrões de reabsorção por substituição ente os grupos esplintados e não esplintados. Segundo o autor, as forças excessivas não previne ou elimina a ancilose em dentes reimplantados após um período extra-alveolar prolongado.

NASJLETI, CASTELLI \& CAFFESSE $^{62}$ em 1982, avaliaram o comportamento dos tecidos periodontais nos dentes reimplantados e esplintados por períodos de 7 e 30 dias em dentes de macacos. O grupo de dentes que recebeu esplintagem por 7 dias não sofreu alterações na cicatrização periodontal, enquanto naqueles que receberam por 30 dias foram observadas reabsorções radiculares e ancilose. Sendo assim, sugeriram que após o reimplante dentário a cicatrização do periodonto se dá melhor com o tempo de esplintagem breve. 
No ano seguinte, KRISTERSON \& ANDREASEN ${ }^{51}$ avaliaram o efeito da esplintagem rígida com a resina acrílica por 2 ou 6 semanas sobre a cicatrização periodontal e pulpar após auto-transplante dentário em macacos. Numa análise após 8 semanas e usando os mesmos parâmetros do estudo anterior, foi demonstrado que independentemente do tempo da esplintagem a extensão da necrose pulpar e reabsorção radicular inflamatória aumentou comparando-se com os dentes não esplintados, além disso, a extensão do periodonto normal diminuiu nos dentes esplintados. Os autores concluíram que a esplintagem exerceu um efeito danoso sobre a cicatrização periodontal e pulpar após o auto-transplante dentário.

Segundo BLOMLÖF et al. ${ }^{25}$ no mesmo ano, a reabsorção radicular de dentes reimplantados é dependente da duração do período extra-alveolar e do meio de manutenção destes. Neste estudo, o significado da preservação da umidade do ligamento periodontal durante o período extra alveolar foi testado nas células isoladas dos dentes reimplantados em macacos. Após a cultura destas células aproximadamente $70 \%$ delas estavam vitalizadas e $44 \%$ restabelecidas após 1 hora numa condição de umidade atmosférica, ou seja, 100\% de umidade. Praticamente nenhuma célula estava vital ou a sua forma vital fora restabelecida após 1 hora de secagem. Dentes reimplantados que foram embrulhados com o filme de plástico por 1 hora antes da reimplantação, não mostraram reabsorção maior do que aqueles que foram reimplantados imediatamente. Isto se contrasta aos dentes que foram mantidos secos por 1 hora antes da reimplantação que demonstraram extensa reabsorção em quase toda raiz. Deste modo, a prevenção 
da evaporação do fluído issular do ligamento periodontal deve ser considerado como objetivo primário, quando não é possível reimplantar imediatamente.

ANDERSSON et al. ${ }^{2}$ em 1984, avaliaram a ancilose dento alveolar após o reimplante dentário experimental, utilizando parâmetros como: radiografias, percussão dentária, mobilidade dos dentes e análise histológica. Áreas de ancilose foram evidentes radiograficamente somente quando estavam localizadas nas superfícies proximais. Na percussão o som era discreto e a mobilidade era normal em todos os dentes não ancilosados tanto quanto naqueles dentes que demonstraram histologicamente ancilose menor que 10\% da superfície radicular. Quando a ancilose afetou de 10 a $20 \%$ da superfíicie radicular, 2 em cada 4 dentes alteraram o som à percussão, passando de discreto a alto e esses dentes não mais mantinham a mobilidade normal. Quando mais de $20 \%$ da superfície radicular estava afetada, o som à percussão era muito alto em todos os dentes e nenhuma mobilidade estava presente.

No ano seguinte, ANDERSSON et al. ${ }^{4}$ investigaram experimentalmente a influência do estímulo mastigatório sobre ancilose dentoalveolar após a reimplantação dos dentes avulsionados que foram mantidos fora do alvéolo por 1 hora e nenhuma esplintagem fora aplicada. Um grupo de animais recebeu alimentação sólida e o outro recebeu alimentação pastosa durante 8 semanas. As condições periodontais foram avaliadas histologicamente após este período. Os resultados mostraram que para o grupo que recebeu alimento sólido, os dentes apresentaram ancilose significativamente menor e uma área maior de ligamento periodontal normal em torno da raiz do que para o grupo que recebeu alimento pastoso. Segundo os autores, o desenvolvimento da 
ancilose parece ser parcialmente prevenido ou reduzido pelo estímulo mastigatório ou funcional.

Já no ano de 1986, HAMMARSTRÖM et al. ${ }^{37}$ revisaram os conceitos sobre a avulsão e o reimplante dentário. Segundo os autores, as fibras colágenas formam a maior parte do cemento e são responsáveis pela inserção do ligamento periodontal. Foi sugerido que o cemento que forma uma barreira efetiva entre a dentina e o ligamento periodontal é crítico para o início e a progressão da reabsorção radicular. Ainda mais, uma vez lesionado ele não pode ser regenerado. Durante a avulsão e o reimplante dentário, pequenos danos mecânicos na superfície do cemento são ocorridos e esses resultam em reabsorção de lacuna rasa observada logo após o reimplante, denominado reabsorção de superfície. Sob circunstâncias favoráveis, isto é, se a vitalidade do ligamento periodontal não foi comprometida e a polpa e a dentina não foram contaminados por bactérias, a cicatrização rápida do periodonto e da superfície radicular pode ocorrer. Aposição do cemento reparativo dentro desta lacuna é usualmente completada em 14 dias.

Ainda no mesmo ano, HAMMARSTRÖM et al. ${ }^{36}$ avaliaram o efeito do uso de antibiótico (penicilina sistêmica) em macacos que tiveram os dentes reimplantados experimentalmente. Na avaliação histológica de 8 semanas após o reimplante, observaram que com o uso de antibiótico no momento do reimplante não ocorreu reabsorção inflamatória, enquanto que, nos animais que receberam tardiamente, 3 semanas após o reimplante, não houve redução da reabsorção inflamatória quando comparados com um grupo que não recebeu nenhuma 
medicação. Porém, a administração do antibiótico não impediu que formasse ancilose em todos os grupos.

Em 1988, BLÖMLOF, LINDSKOG \& HAMMARSTRÖM ${ }^{27}$ avaliaram a cicatrização da superfície radicular na qual o ligamento periodontal e cemento foram removidos mecanicamente a partir da junção cemento-esmalte até o terço médio da raiz de dentes extraídos e em seguida reimplantados. As áreas que não sofreram dano mecânico se restabeleceram em 1 mês e ocasionalmente áreas isoladas de reabsorção de superfície foram vistas e em algumas vezes com cemento reparativo. O número reduzido de núcleos celulares corados no ligamento periodontal nos primeiros dias indicou necrose parcial. Após 1 semana o número de fibroblastos aumentou e por volta de 4 semanas a superfície da raiz estava coberta por um tecido conjuntivo aparentemente normal contendo fibroblastos. Em áreas onde o ligamento periodontal e o cemento foram removidos mecanicamente em conjunção ao fator inflamação pela presença de placa bacteriana, houve a proliferação de epitélio apicalmente, deste modo impedindo a inserção do tecido conjuntivo.

AUYEUNG, BOUWSMA \& POLSON ${ }^{22}$ em 1988, investigaram a relação entre inserção de fibras na superfície da raiz e susceptibilidade à reabsorção radicular. Na região apical da raiz a densidade de fibras foi significativamente menor, mas o diâmetro das fibras foi significativamente maior do que na região do terço cervical e médio. $O$ resultado entre a densidade e o diâmetro das fibras mostrou que, a ocupação das fibras foi na ordem de $58 \%$ para o terço apical, $70 \%$ para o terço cervical e $74 \%$ para o terço médio. Segundo os autores, a representação tridimensional da inserção de fibras intimamente 
ligadas à superfície do cemento e junto com os cementoblastos promovem uma barreira mecânica ao processo exploratório por osteoclastos, concluindo assim que as diferenças na ocupação de inserção de fibras pode contribuir para 0 aumento da susceptibilidade da reabsorção radicular.

Enxerto autógeno de epitélio do órgão do esmalte ou epitélio da cavidade bucal foram implantados em cavidades confeccionadas experimentalmente em raízes extraídas e em seguida reimplantadas e avaliadas histologicamente por LINDISKOG, BLOMLÖF \& HAMMARSTROM ${ }^{55}$ em 1988. Observou-se a cicatrização com a formação de cemento reparativo em todos os casos, inclusive em dentes controles que não receberam nenhum tipo de enxerto celular. Somente no grupo experimental com epitélio do órgão do esmalte, a presença de ilhotas de células epiteliais promoveu ao seu redor a eabsorção óssea, impedindo assim a proliferação óssea na cavidade experimental, enquanto que nos outros grupos apesar do restabelecimento das estrututras periodontais, não se impediu que o osso alveolar avançasse dentro da cavidade. As células epiteliais da cavidade bucal não mostraram a capacidade de sobrevivência no interior do tecido conjuntivo do ligamento periodontal. Isto indica que o epitélio do órgão do esmalte exerce um papel na manutenção da largura do ligamento periodontal e além disso, exerce um papel adicional de não permitir a ancilose.

Ainda neste ano, TRONSTAD ${ }^{81}$ classificou a reabsorção dentária em inflamatória transitória ou progressiva e por substituição. A reabsorção inflamatória transitória, também chamada de reabsorção de superfície, ocorreria frequentemente em dentes traumatizados, em dentes que sofreram movimento 
ortodôntico e naqueles que se submeteram ao tratamento periodontal. Mas também pode ser visto aparentemente como resultado de desgaste fisiológico dos dentes. Os tecidos mineralizados ou da área desnuda da superfície radicular atrairiam células de origem clástica, as quais colonizariam a área danificada. Porém, estas requerem estímulo contínuo durante a fagocitose, e a estimulação da superfície radicular desnuda parece não ser suficiente para sustentar 0 processo de reabsorção por mais de 2 a 3 semanas. Segundo o autor, este tipo de reabsorção não apresenta importância clínica e nem radiográfica. A reabsorção inflamatória progressiva pode ser iniciada pelo desnudamento da superfície radicular mineralizada e prolongada pela irritação mecânica ou pelo aumento da pressão sobre o tecido, infecção do canal radicular e na dentina, e por doenças sistêmicas. Embora em dentes luxados a reabsorção radicular seja iniciada pelo trauma mecânico na superfície da raiz, o processo de reabsorção é mantido pelo estímulo microbiano oriundo do canal radicular infectado, o qual fornece a estimulação contínua para as células clásticas. A reabsorção por substituição também chamada de ancilose ocorre após uma necrose extensa do ligamento periodontal com a formação do osso sobre uma área desnuda da superfície radicular. Clinicamente, a condição é quase sempre uma complicação das injúrias por luxação, especialmente em dentes avulsionados que se mantiveram por tempo prolongado fora do alvéolo. Se menos de $20 \%$ da superfície radicular é envolvido, a reversibilidade da ancilose poderia ocorrer. Se isto não ocorresse, os dentes ancilosados seriam incorporados no osso alveolar e se tornariam como parte do processo de remodelação normal do osso alveolar. Consequentemente, eles seriam gradualmente reabsorvidos e substituídos por 
osso alveolar, e por esta razão, o termo reabsorção por substituição. As células envolvidas na reabsorção por substituição seriam os osteoclastos normalmente envolvidos na remodelação óssea. Embora este tipo de reabsorção leve a uma destruição completa do dente, segundo o autor, não deveria ser considerada como uma doença. Este processo ocorreria como um equívoco, porque as células envolvidas na remodelação óssea não seriam capazes de distinguir entre cemento radicular, dentina e osso alveolar. Os osteoclastos reabsorveriam os tecidos dentários tão prontamente como no osso e os osteoblastos que não são capazes de formar dentina ou cemento em condições normais, subsequentemente preencheriam as lacunas com osso alveolar.

ANDERSSON \& BODIN ${ }^{3}$ em 1990, descreveram uma análise radiográfica por um estudo longitudinal, o efeito do reimplante dentário em humanos, no qual os dentes permaneceram fora do alvéolo por 15 minutos. Dos 21 dentes avaliados 7 destes não apresentaram qualquer tipo de reabsorção durante o período de observação. Em 8 dentes cavidades rasas de reabsorção foram vistas, mas sem sinais de progressão durante todo o período, e em outros 6 dentes reabsorção progressiva foi vista. Segundo os autores, o grau de reabsorção radicular dos dentes reimplantados após um período de 15 minutos após a avulsão mostrou um prognóstico favorável a longo prazo.

BLOMLÖF \& LINDSKOG $^{26}$ em 1994, avaliaram a formação do cemento reparativo sobre as superfícies radiculares instrumentadas experimentalmente em macacos. Os dentes foram extraídos com cuidado usando fórceps e em seguida foram removidos entre 1 e $2 \mathrm{~mm}$ de cemento e ligamento periodontal das superfícies proximais tanto na região cervical como na apical, e 
na sequência, os dentes foram reimplantados. A ancilose foi vista em ambas as áreas após 3 e 5 semanas, embora em menor grau em 5 semanas e virtualmente ausente em 10 semanas. Neste período, uma camada remanescente de tecido mineralizado, normalmente referido como cemento reparativo foi visto recobrindo as superfícies de dentina exposta parecendo não estar firmemente inserido na superfície radicular. Apresentava uma aparência multi-laminar, lembrando osso alveolar e as fibras do tecido conjuntivo adjacente a este tecido não possuíam orientação funcional, ao invés disso, a sua orientação era paralela à superfície radicular. Conclui-se que a formação de tecido mineralizado ou cemento reparativo foi o resultado da ancilose transitória.

ANDREASEN et al. ${ }^{16}$ em 1995, numa análise de variância estatística múltipla, revelaram que os 4 fatores que tiveram grande impacto sobre a cicatrização do ligamento periodontal após o reimplante dentário foram: estágio de desenvolvimento da raiz, extensão do período de secagem do dente fora do alvéolo, reimplantação imediata e manutenção da umidade por estocagem nos meios de saliva ou solução salina. Segundo os autores, a reimplantação imediata foi um dos fatores mais importantes na contribuição para cicatrização do ligamento periodontal. Apesar disso, um experimento em animal mostrou resultado semelhante em dentes que foram reimplantados tardiamente em até 18 minutos sem nenhuma contaminação externa ${ }^{12}$. Com relação ao efeito da antibioticoterapia sobre a cicatrização do ligamento periodontal declararam que, apesar da redução na extensão da reabsorção vista após a administração de penicilinas, nenhum dos dentes esteve livre da reabsorção radicular. 
No mesmo ano, GÜNDAY, SAZAK \& TÜRKMEN ${ }^{35}$ avaliaram a reabsorção radicular utilizando microscopia eletrônica após o reimplante de dentes incisivos em cães. Três grupos de 3 dentes foram mantidos em solução salina por 5, 30 e 120 minutos antes da reimplantação. No primeiro grupo, os dentes foram reimplantados com a polpa intacta, e no segundo e terceiro, os dentes tiveram a polpa extirpada e o preenchimento do conduto com hidróxido de cálcio. A análise da região apical dos dentes após 90 dias mostrou um comprometimento por reabsorção inflamatória em todos os grupos. A reabsorção foi vista com maior intensidade nos grupos 1 e 3 , no primeiro grupo que não recebeu $\mathrm{CA}(\mathrm{OH}) 2$, mesmo com a permanência breve fora do alvéolo antes da reimplantação, isto deveu-se em função da necrose pulpar, ainda assim, no restante da raiz quando foi encontrada a reabsorção de superfície, era predominantemente sem ancilose, e no segundo grupo o fator período extraalveolar foi decisivo no desenvolvimento da reabsorção radicular.

O uso de tetraciclina e amoxicilina administrados sistêmicamente com objetivo de inibir a reabsorção após reimplante dentário em cães foi relatado por SAE-LIM et al. ${ }^{71}$ em 1998. Os dentes foram extraídos e mantidos secos por 1 hora para resultar em dano severo do ligamento periodontal antes da reimplantação dos mesmos. Para os grupos experimentais foram administrados tetraciclina hidroclorada ou amoxicilina. Após 12 e 16 semanas, os animais foram sacrificados e as áreas experimentais foram avaliadas histologicamente. Os grupos com amoxicilina e de controle apresentaram grau de cicatrização inferiores em relação ao grupo do tetraciclina $(10,9 \%, 11,28 \%$ e $35,45 \%$ respectivamente). A ocorrência da cicatrização completa para o grupo da 
amoxicilina não foi diferente do grupo controle. Esta similaridade na cicatrização sugere que a causa da reabsorção primária não é a bactéria, uma vez que presumidamente ela estava ausente, e relataram que a tetraciclina possui atividade anti-reabsortiva, enquanto que a amoxicilina não apresentou esta atividade.

Em um outro estudo, ainda no mesmo ano, SAE-LIM, WANG \& TROPE $^{72}$ compararam histologicamente a efetividade da tetraciclina e amoxicilina na limitação da reabsorção inflamatória pelo controle da infecção pulpar de dentes reimplantados em cães. Foram administrados antibióticos diariamente durante 7 dias. A dosagem da tetraciclina foi de $250 \mathrm{mg}, 3$ vezes ao dia e a amoxicilina foi de $250 \mathrm{mg}, 2$ vezes por dia. Apos 6 meses os animais foram sacrificados e as peças foram preparadas para avaliação histológica. Para o grupo da te traciclina, a cicatrização foi de 67,22 \% e a reabsorção inflamatória de $32,78 \%$, sendo que para o grupo de amoxicilina foi $56,88 \%$ e $43,12 \%$ respectivamente. Consideraram os autores que apesar da pequena melhora da tetraciclina sobre a amoxicilina, o resultado é pouco significativo estatisticamente. Segundo os autores, a tetraciclina pode ser uma boa opção alternativa para prevenção da reabsorção inflamatória e com a propriedade antimicrobiana.

\subsection{Extrusão cirúrgica}

Uma outra modalidade de tratamento em casos de invasão das distâncias biológica é a extrusão cirúrgica, inicialmente denominada transplante dentário intra-alveolar, que apresenta características biológicas semelhante a um reimplante dentário. Segundo TEGSJÖ, VALERIUS-OLSSON \& OLGART ${ }^{80}$ 
(1978), fraturas cervicais transversais e obliquas intra-alveolares representam grande problema no âmbito odontológico, particularmente em jovens que muitas vezes necessitam recorrer ao procedimento de exodontia. Foi relatado pela primeira vez, um método cirúrgico que foi aplicado em dentes com fraturas subgengivais de adolescentes para em seguida restabeler a condição protética. A técnica cirúrgica descrita neste relato iniciou-se com incisão relaxante nas papilas dos dentes adjacentes se extendendo até a mucosa alveolar, sendo os retalhos vestibular e lingual deslocados. Neste momento os fragmentos na porção coronária da raiz foram removidos e a polpa extirpada. O retalho vestibular foi elevado até a região do ápice radicular e uma porção de osso apical foi removido com brocas e cinzéis e ainda, toda e qualquer curvatura da raiz presente foi removida por apicectomia nesta fase. Então o dente foi luxado e extruído até estar clinicamente acessível, e esta luxação foi realizada no sentido ápico coronal com instrumento em forma de saca-prótese apoiando-se no ápice radicular. Os autores sugeriram que, em alguns casos a raíz deva ser rotacionada na hora do reposicionamento dependendo do término da fratura oblíqua para deixar numa posição mais favorável em relação à mar gem óssea. Após o posicionamento do dente, a loja óssea aberta anteriormente na porção apical foi preenchida com enxerto ósseo para evitar deslocamento de intrusão do dente e em seguida realizoutse a sutura firme dos retalhos para auxiliar na manutenção da nova posição do dente. Instruções de higiene bucal e dieta pastosa foram passadas ao paciente e antibioticoterapia com penicilina foi prescrita por 10 dias. Em 12 pacientes tratados com esta técnica os resultados clínico e radiográfico após 4 a 8 meses fo ram: regeneração óssea apical , sem ancilose ou reabsorção radicular, 
sem nenhum efeito negativo aos dentes adjacentes e mobilidade clínica normal em 4 semanas. Ainda segundo os autores, o tratamento endodôntico deveria iniciar após 4 a 6 semanas e o tratamento protético restaurador tão logo possível para minimizar o risco de ancilose.

KAHNBERG, WARFVINGE \& BIRGERSSON ${ }^{46}$ em 1982, relataram a técnica de transplante intra-alveolar com enxerto ósseo autógeno na região periapical em 15 pacientes que sofreram fraturas cervicais desfavoráveis. As raízes foram tracionadas cirurgicamente numa média de $4,5 \mathrm{~mm}$ e enxertos ósseos na região apical serviram de suporte para sua manutenção. Na maioria dos casos em 3 semanas de cicatrização houve a estabilização das raizes, mas apesar disso, o grau de mobilidade dentária dependeu da extensão da tração radicular. O controle radiográfico demonstrou que após 3 meses houve a normalização do ligamento periodontal, embora foram vistas pequenas reabsorções radiculares apicais limitadas e sem progressão em 10 casos, as quais não comprometeram o resultado final segundo os autores.

A simplificação da técnica de extrusão cirúrgica foi descrita por KAHNBERG ${ }^{43}$ em 1985. Na técnica original que preconizava a extrusão da raiz por pressão ápico-coronal usando um instrumento como saca-prótese e da estabilização desta com o enxerto ósseo autógeno na região apical foram eliminados. Ao invés disso utilizou a técnica convencional de exodontia com luxação, apreensão e avulsão da raiz, preconizando a estabilização inicial por suturas interproximais e uso de cimento cirúrgico por 1 semana. Foram avaliados um total de 23 dentes que receberam esta técnica cirúrgica. O ligamento periodontal normal estava presente após 3 meses em todos os casos, sinais de 
reabsorção radicular de superfície foram observados em 2 casos, no entanto, sem progressão e pequena radioluscência periapical foi vista em outros dois. Isto se deveu provavelmente pela reação à presença de material obturador endodôntico em excesso. Pequena remodelação do osso marginal adjacente as raizes extruídas foram observadas em 8 casos. Aos 2 anos de observação, todos os pacientes controlados apresentaram características clínicas de normalidade.

TEGSJÖ et al. ${ }^{79}$ em 1987, em uma avaliação da condição clínicoradiográfica de 56 dentes que sofreram transplante intra-alveolar concluíram que a esplintagem naqueles dentes deveria ser evitada com o propósito de restaurar a função da raiz tão breve quanto possível para prevenir ancilose. A avaliação da mobilidade dos dentes transplantados mostrou que em 7 semanas todos os dentes obtiveram sua normalidade clínica.

No ano seguinte, KAHNBERG ${ }^{44}$ avaliou os dois métodos cirúrgicos para extrusão da raiz descritos anteriormente com uso de fórceps e saca-prótese. A imobilização em ambos os grupos foi apenas com suturas interproximais e aplicação de cimento cirúrgico. Em algumas situações os dentes foram invertidos de vestibular para lingual em função da fratura. A avaliação clínico-radiográfica foi realizada em 3 e 12 meses e anualmente durante 7 anos. Segundo o autor, os resultados da extrusão cirúrgica em dentes com fratura cervical são encorajadores, visto que nenhum dos dentes em ambos os grupos foi perdido. Pequena reabsorção apical foi vista em 17 dentes, embora nenhum destes mostrou o processo progressivo. Proporcionalmente a reabsorção apical foi maior no grupo da extrusão original com enxerto ósseo. As complicações endodônticas e lesões periapicais desenvolveram em quase $30 \%$ dos dentes. Para os autores, 
isto foi devido ao tratamento endodôntico inadequado isentando qualquer envolvimento com o procedimento cirúrgico.

Segundo WARFVINGE \& KAHNBERG ${ }^{84}$ em 1989, o tratamento endodôntico de um dente a ser transplantado deveria ser instituído após o transplante, reduzindo assim a repetição do tratamento endodôntico e simplificando o trabalho clínico com o paciente traumatizado. Foi realizado um estudo evolvendo 26 dentes uni-radiculares com fraturas corono-radiculares que receberam transplante intra-alveolar. Foram divididos em dois grupos com 13 dentes cada, sendo que no primeiro grupo, o tratamento endodôntico com isolamento relativo foi realizado antes do transplante intra-alveolar e no segundo grupo, após 3 a 4 semanas, com o isolamento absoluto. Testes bacteriológicos mostraram que 0 tratamento endodôntico após 0 transplante foi preferível e 0 índice de retratamento endodôntico por infecção foi menor neste grupo. Isto deveu-se provavelmente pelas condições de controle asséptico.

Uma avaliação clínico-radiográfica longitudinal por 10 anos em pacientes que receberam método cirúrgico de transplante intra-alveolar (extrusão cirúrgica) foi revelada por KAHNBERG ${ }^{45}$ em 1996. Ao todo foram 21 dentes e a extrusão da raiz variou de 3 a $8 \mathrm{~mm}$ com uma média de 5,2 $\mathrm{mm}$. Todos os dentes receberam restaurações protéticas de diferentes materiais e nenhuma evidência importante clínica e/ou radiográfica de condições patológicas foram observados durante todo o período de acompanhamento; somente uma leve alteração na porção apical que não excedeu $0,5 \mathrm{~mm}$ foram vistas em 5 raizes, porém sem implicação clínica. A remodelação marginal do osso alveolar foi observada em todos os dentes transplantados, apesar da largura do espaço do ligamento 
periodontal aumentar em função da diminuição do diâmetro da raiz extruída. Somente um dente teve de ser extraído por motivo de reabsorção radicular externa no terço cervical. Segundo o autor, o método modificado e simplificado da extrusão cirúrgica é mais aplicável na prática clínica e que este resultado estimula a aplicação deste para solucionar fraturas cervicais subgengivais.

Em contrapartida, MAGINI et al. ${ }^{57}$ em 1998, apresentaram indicações de tracionamento cirúrgico em dentes com invasão da unidade dentogengival por cáries, fraturas corono-radiculares, perfurações ou reabsorções radiculares. Os autores indicaram a esplintagem semi rígida, com o fio de nylon e resina composta após a extrusão imediata, e o acompanhamento deveria ser realizado quinzenalmente preservando a contenção até a visualização radiográfica da cortical alveolar (lâmina dura). Um período de 3 meses em média seria necessário para restruturação do espaço do ligamento periodontal na nova posição dentro do alvéolo. Descreveram os autores que a contenção semi-rígida é a mais indicada por permitir pequenos movimentos, assim minimizando ou evitando pequenos locais de reabsorção por substituição.

O procedimento de extrusão cirúrgica como alternativa na terapêutica periodontal para restabelecer distâncias biológicas em pacientes adultos que apresentavam invasão destas por motivo de cáries subgengivais, em estado de raiz com destruição profunda, e ainda em situação clínica desfavorável para execução de outras modalidades de tratamento foi relatado por KIM et al. ${ }^{48}$ (2001) e por KIM, TRAMONTINA \& PASSANEZI ${ }^{47}$ (2002). Nos relatos clínicos foram apresentadas as modificações e adaptações da técnica cirúrgica de extrusão descrita inicialmente por KHANBERG ${ }^{43}$ e TEGSJÖ80 ${ }^{80}$ O procedimento 
iniciou-se com a retirada completa da cárie na porção cervical da raiz a fim de estabelecer uma referência de dentina saudável para as futuras dimensões biológicas. Em seguida o levantamento do retalho total sem incisões relaxantes até a crista óssea foi confeccionada preservando toda a estrutura do tecido gengival, neste momento iniciou-se a luxação da raiz com um cinzel de Fedi e alavanca pediátrica, e a avulsão da raiz com fórceps pediátrico. Após a avaliação visual da raiz avulsionada, a raiz foi introduzida no alvéolo e mantida numa posição mais coronal, expondo toda região cervical. A estabilização se fez somente pelas suturas interproximais e não foi utilizado cimento cirúrgico. Segundo os autores, este procedimento além de ser conservador, apresenta vantagens como diminuição do tempo operatório e do próprio tempo total de tratamento, principalmente quando comparado com a extrusão ortodôntica; mas, quando comparado com o retalho posicionado apicalmente com osteotomia, pode-se dizer que é extremamente conservador, sendo possível a manutenção completa da arquitetura gengival e óssea, mantendo as característica estéticas. Por outro lado, deve se levar em consideração da necessidade de manter a proporção coroa / raiz mínima de 1:1 para a obtenção da estabilidade fisiológica do dente.

\subsection{Extrusão Ortodôntica}

OPPENHEIM ${ }^{65}$ em 1940, demonstrou histologicamente a presença de tecido osteóide recém formado sobre a crista óssea alveolar através do processo de "alongamento" das fibras do ligamento periodontal. Usando forças leves e intermitentes relatou a aposição passiva do osso, que ocorreu sem dano 
ao ligamento periodontal. $\mathrm{O}$ autor considerou que $\mathrm{o}$ alongamento das fibras do ligamento periodontal, sendo breve e intermitente, não provoca alterações nas células, permitindo assim uma rápida recuperação das mesmas. Sugeriu ainda, que o tecido osteóide formado durante os períodos de repouso após forças intermitentes é mais resistente a reabsorção. Surgiu assim um novo conceito para ser aplicado no tratamento periodontal em situações de comprometimento das distâncias biológicas, o movimento por "alongamento"

HEITHERSAY ${ }^{39}$ em 1973, propôs a utilização de extrusão ortodôntica de dentes fraturados transversalmente em nível subgengival. Os dentes foram tratados endodonticamente, receberam coroas provisórias e então, a colocação do aparato ortodôntico. Em seguida, os dentes foram tracionados coronalmente com forças controladas, por um período médio de 4 semanas e contenção subsequente de 6 semanas. $O$ autor sugeriu a necessidade da cirurgia periodontal para correção da arquitetura gengival.

PASSANEZI, ALVES, JANSON \& NAHÁS ${ }^{67}$ em 1974, sugeriram a tração coronal ortodôntica em lugar de cirurgia periodontal ressectiva para obtenção de novas distâncias biológicas. Segundo os autores, a cirurgia com osteotomia apresenta prejuízo na inserção periodontal como também do comprometimento estético local.

No mesmo ano, INGBER ${ }^{40}$ relatou em seu artigo a possibilidade de utilização da extrusão ou "erupção forçada" pelo uso de aparelho ortodôntico no tratamento de defeitos infra-ósseos isolados de 1 ou 2 paredes relatando a resolução dos defeitos, porém com a desvantagem da diminuição na proporção coroa-raiz do dente submetido a extrusão. Mesmo assim, segundo o autor, esta 
seria uma alternativa viável para eliminação de defeitos periodontais sem que haja prejuízo nos tecidos de suporte periodontal dos dentes adjacentes.

No ano de 1976, INGBER ${ }^{41}$ relatou que a extrusão ortodôntica seria indicada também nos casos em que a perda de estrutura dental por cárie, fratura, preparos protéticos inadequados e outros, ocorra abaixo da margem gengival ou abaixo da crista óssea, tendo como objetivo buscar a manutenção das distâncias biológicas, acesso às técnicas de moldagem, restauração da função, manutenção da saúde periodontal e estética. O autor relatou ainda, que a mobilidade pós tratamento varia consideravelmente dependendo das características anatômicas da raiz tracionada bem como da quantidade de extrusão necessária para se atingir o objetivo. A mobilidade residual segundo o autor, quando existente não deve comprometer a função.

Por outro lado, SIMON, LYTHGOE \& TORABINEJAD ${ }^{74}$ em 1980, descreveram uma análise clínica e histológica da resposta biológica ao movimento de tração coronal ortodôntica em dentes pré-molares de cães. $\mathrm{Na}$ avaliação histológica, observaram alargamento inicial do ligamento periodontal com desorganização e estiramento das fibras periodontais, o epitélio juncional permaneceu na região da junção cemento-esmalte em todo o experimento e a neoformação óssea se manifestou na segunda semana. Além do mais, neste período observou-se a reorganização das fibras do ligamento periodontal, ao mesmo tempo em que toda a área da bifurcação esteve inalterada. Ainda segundo os autores, a reestruturação das fibras do ligamento periodontal pode ocorrer por volta de 7 semanas após a movimentação dentária em cães. 
A extrusão ortodôntica para dentes fraturados subgengivalmente foi discutida por COOKE \& SCHEER ${ }^{30}$ em 1980. Os autores propuseram a utilização de aparelhos ortodônticos removíveis, com troca dos elásticos e controle diário pelo paciente e semanal pelo profissional, resultando em menor risco de intrusão dos dentes adjacentes da ancoragem, maior facilidade de higienização, simplicidade técnica e de baixo custo.

No ano seguinte, STERN \& BECKER ${ }^{76}$ fizeram considerações sobre o tratamento de dentes fraturados ou com cárie subgengival. Os autores afirmaram que dois tipos de tratamento poderiam ser aplicados: o primeiro seria a diminuição cirúrgica da crista alveolar em 2 a 3 mm, o que traria conseqüências negativas em relação à inserç ão periodontal e comprometimento estético; o segundo seria erupção forçada do dente, definida como um movimento de extrusão do complexo dente - periodonto, que ocorreria a nova formação das estruturas periodontais.

Numa avaliação clínica de 12 casos de extrusão coronal, LEMON ${ }^{52}$ em 1982, relatou que em 2 semanas pode ocorrer extrusão de até 2 a $3 \mathrm{~mm}$. Ainda segundo o autor, é necessário a estabilização de 1 mês para cada milímetro de extrusão provocada, isso é função da reorganização das fibras do ligamento periodontal.

VAN VENROOY \& YUKNA ${ }^{83}$ em 1985, avaliaram a viabilidade do tratamento de dentes com doença periodontal induzida experimentalmente pela técnica de tração coronária ortodôntica em cães. Os dentes extruídos apresentaram profundidade de bolsa e inflamação gengival menores. A análise histológica revelou na área œrvical a formação de novo osso, maior espessura 
do cemento e a manutenção do ligamento periodontal, porém, com o seu espaço alargado, enquanto que na região apical apresentou maior formação óssea e menor espessura do cemento. Segundo os autores, o movimento de extrusão dentária pode ter efeitos positivos no tratamento da doença periodontal avançada.

No ano seguinte, BENENATI \& SIMON²3 ponderaram que a técnica de extrusão dentária pode ser utilizada nos casos de cáries, fraturas radiculares, perfurações iatrogênicas e reabsorções subgengivais, desde que o comprimento radicular fosse, no mínimo, igual ao da nova coroa dentária. Afirmaram ainda que, para o tempo gasto na extrusão dentária de aproximadamente de 2 a 3 semanas, o tempo de estabilização proposto foi de 8 a 12 semanas.

Já JOHNSON \& SIVERS ${ }^{42}$, no mesmo ano, afirmaram que a erupção forçada promove o restabelecimento das distâncias biológicas. Segundo os autores, a contenção dos dentes movimentados visa permitir reestruturação do ligamento periodontal, visto que sua remoção antes do período de tempo preconizado poderia resultar em intrusão radicular. Propuseram que o período de estabilização de 2 meses é suficiente na maioria das vezes.

Segundo RIES, JOHNSON \& NIEBERG ${ }^{70}$ em 1988, a extensão da terapia de tração coroanal depende da quantidade desejada e de fatores anatômicos da forma da raiz. Para cada milímetro de extrusão seria necessária 1 semana e meia de movimento ativo, com intensidade de força inferior a $30 \mathrm{~g}$. Recomendam ainda, a estabilização de 6 a 8 semanas, para a reorganização do ligamento periodontal e para prevenir intrusão radicular. 
As alterações vasculares decorrentes da aplicação de força para extrusão dentária contínua por 30 minutos com $1 \mathrm{~N}$ de intensidade em dentes molares de ratos foi estudado por $\mathrm{LEW}^{53}$ em 1989. Alterações degenerativas nas células da parede endotelial foram observadas em cerca de $30 \%$ das vênulas pós capilares e $18 \%$ dos capilares, valores estes estatísticamente significantes quando comparados com o ligamento periodontal normal. Os resultados sugeriram que forças contínuas podem levar a alterações degenerativas nos segmentos venosos mais vulneráveis do sistema vascular periodontal.

No ano seguinte, seguindo este raciocínio $\mathrm{STROSTER}^{78}$, fez considerações sobre a intensidade da força aplicada no movimento de extrusão dentária e propôs que a força necessária para extruir um dente não deveria exceder 25 a $30 \mathrm{~g}$, prevenindo assim, reabsorção radicular externa ou ancilose. Segundo o autor, a duração do tratamento depende de fatores como hospedeiro, alinhamento dentário, variabilidade periodontal, quantidade de movimento desejado e idade do paciente. Como existe a força intrusiva da mesma intensidade e de sentido contrário ao movimento de extrusão, o autor recomendou a estabilização dos dentes por um período de um mês para cada milímetro extruído.

NEDER ${ }^{63}$ em 1996, estabeleceu a racionalização metodológica do movimento ortodôntico em função do envolvimento das distâncias biológicas estar associado a comprometimento dentário e periodontal. Para os casos de comprometimento dental partiu-se da premissa que a recuperação das distâncias biológicas requer a exposição da superfície dentária em nível supra-ósseo adequado e portanto o movimento ortodôntico visa extruir o dente para fora do 
alvéolo cerca de 2 a $3 \mathrm{~mm}$, para tanto é indicado a tração coronal rápida. Por sua vez, nos casos de bolsas periodontais e recessão gengival é desejável que os tecidos periodontais acompanhem o movimento, quer eliminando a bolsa, quer recuperando o nivelamento da crista óssea alveolar, com conseqüente redução da coroa clínica visual, e nesta situação é indicada tração coronal lenta.

STEVENS \& LEVINE$^{77}$ em 1998, exploraram as indicações e contra-indicações do procedimento de erupção forçada. Segundo os autores as indicações seriam: fraturas horizontal, de áspide, ou em bisel; destruição por cárie, reabsorção externa inflamatória, reabsorção interna com a perfuração do terço cervical; perfuração iatrogênica; e extração intencional. As contraindicações seriam: comprimento da raiz insuficiente após a extrusão para restauração; espaço funcional insuficiente para extrusão da quantidade necessária; e complicações periodontais. 
3. PROPOSIÇÃO 


\section{3 - PROPOSIÇÃO}

Com base na revisão da literatura e no que foi delineado na introdução, o propósito deste trabalho foi:

1. Avaliar as alterações histológicas periodontais de dentes submetidos ao procedimento de extrusão cirúrgica em cães adultos, comparando-as àquelas de dentes que foram submetidos ao procedimento de extrusão ortodôntica rápida.

2. Avaliar, por análise descritiva, as alterações histológicas do ligamento periodontal, osso alveolar e superfície cementária, bem como classificar os processos de reabsorções radiculares e a reparação das mesmas.

3. Avaliar criticamente a aplicabilidade da técnica de extrusão cirúrgica como opção terapêutica periodontal no tratamento de invasão das distância biológicas. 
4. MATERIAL E MÉTODOS 


\section{4 - MATERIAL E MÉTODOS}

1. Seleção da amostra

Foram selecionados na Faculdade de Medicina veterinária da PUCPR, 18 cães machos adultos jovens, sem raça definida, em estado saudável e com o peso variando entre 10 e $20 \mathrm{Kg}$, provenientes do canil da Prefeitura do Município de Curitiba-PR. Todos os animais apresentavam a dentição permanente com rizogênese completa na maxila e sem doença periodontal (figura 1).

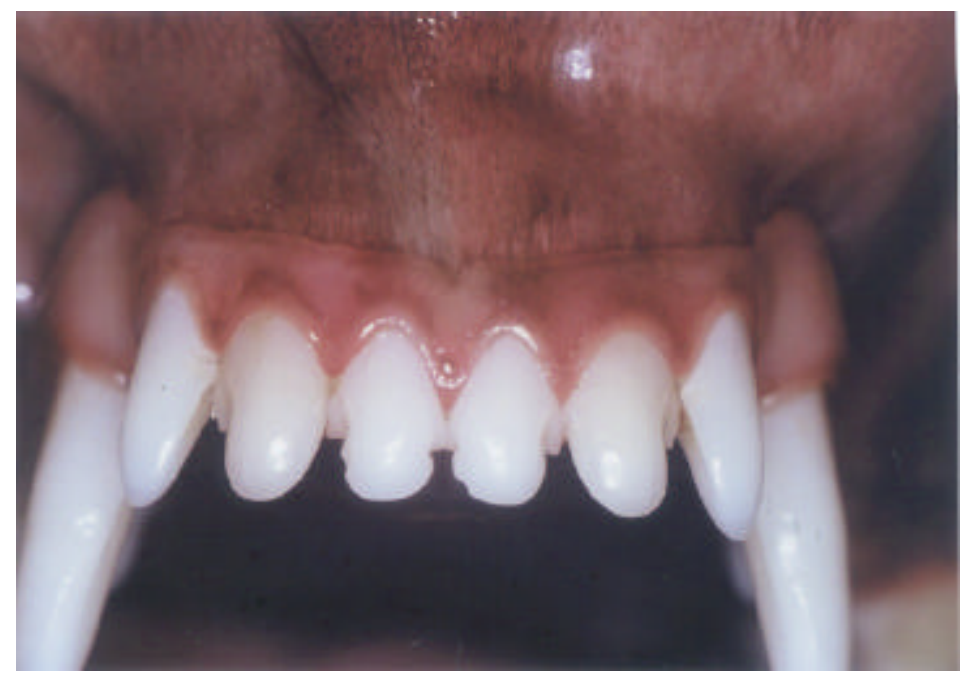

Figura 1 - Aspectos clínicos das áreas selecionadas. Observar as estruturas dentárias e periodontais clínicamente normais. 
2. Protocolo anestésico

- Tranquilização: acepromazina 0,2 \% na dose de 0,1 mg/kg via intra-venosa. (Acepran 0,2\% - Univet)

- Indução anestésica: tiopental sódico na dose de 12,5 mg/kg via intra-venosa. (Thiopentax - Cristália)

- Manutenção da anestesia: halotano a 1,5 \% (Halotano - Cristália) via intubação orotraqueal e tartarato de butorfanol na dose de $0,5 \mathrm{mg} / \mathrm{kg}$ (Torbugesic - Fort Dodge) via intra-muscular.

Após jejum alimentar prévio de 12 horas e hídrico por 6 horas, os animais foram conduzidos à sala de experimentação, onde foram coletados os seguintes parâmetros: frequência cardíaca em batimentos por minuto, freqüência respiratória em movimentos por minuto, temperatura retal em graus Co e ventilometria em $\mathrm{ml}$.

Após a coleta dos parâmetros basais (momento 0), foi administrada acepromazina $0,2 \%$ na dose de $0,1 \mathrm{mg} / \mathrm{kg}$ por via intra-venosa. Decorridos 15 minutos da administração do tranquilizante, foi aplicado o tiopental sódico na dose de $12,5 \mathrm{mg} / \mathrm{kg}$ via intra-venosa, em volume suficiente para proceder a intubação orotraqueal. Logo em seguida, os animais foram posicionados em decúbito dorsal e conectados a um circuito anestésico, filtro valvular, pelo qual a anestesia foi mantida com halotano a 1,5\%, diluído em oxigênio a $100 \%$. halotano foi administrado em concentração suficiente para que o animal fosse mantido em plano de anestesia cirúrgica. A partir da intubação orotraqueal, as variáveis foram obtidas em intervalos de 15 minutos, até o término do experimento. 
Como co-adjuvante da anestesia inalatória foi administrado tartarato de butorfanol na dose de $0,5 \mathrm{mg} / \mathrm{kg}$ por via intra-muscular.

\section{Experimento}

Os animais foram divididos em 6 grupos de 3, sendo cada animal submetido a dois procedimentos de extrusão, o cirúrgico como experimental e o ortodôntico como controle. Para tanto foram escolhidos os dentes $1^{\text {os }}$ incisivos laterais superiores direitos como experimental e $1^{\text {os }}$ incisivos laterais superiores esquerdos como controle.

Após a anestesia, todos os animais receberam antissepsia bucal com a solução de clorhexidina a 0,2 \% (Perio Gard - Colgate) por meio de embrocação com gase.

Todos os dentes do grupo de extrusão ortodôntica e cirúrgica receberam inicialmente tratamento endodôntico convencional com biopulpectomia e obturação do conduto com cones de gutapercha Pontas de gutta percha calibrada - Tanari) e cimento óxido de zinco eugenol (Óxido de zinco - K-dent e Eugenol - Probem) e em seguida o selamento do 1/3 coronário do conduto com cimento óxido de zinco eugenol.

Primeiramente foram realizados os procedimentos de extrusão por movimento ortodôntico usando a força de tracionamento pesada tendo como objetivo a extrusão rápida. Para tanto, foram utilizados elástico em cadeia com espaçamento médio (Elástico corrente preto médio - Morelli) (figura 3).

Inicialmente a coroa dentária foi seccionada ao nível cervical usando uma ponta diamantada, assim obtendo uma referência cervical para a 
movimentação dentária. Em seguida um pino de retenção intra-canal foi confeccionado utilizando fio de aço $0,7 \mathrm{~mm}$ (Fio duro elástico - Morelli), sendo que uma pequena dobra na porção coronária foi realizada neste fio servindo como meio de retenção para o elástico ortodôntico; este pino foi cimentado com cimento fosfato de zinco (Cimento de Zinco - SS White) (figura 2).

O movimento dentário foi promovido pela ativação do elástico em cadeia que ligou o pino de retenção intra-canal a uma ancoragem transversal que foi confeccionada com o fio de aço $0,7 \mathrm{~mm}$ ligando os dentes adjacentes incisivo central e $2^{\circ}$ incisivo lateral no terço incisal, sendo esta ancoragem fixada aos dentes por resina composta (Resina composta Charisma - Heraeus Kulzer). A distância entre a porção coronária do dente desgastado ao fio de aço da ancoragem transversal foi de aproximadamente $3 \mathrm{~mm}$ (figura 3).

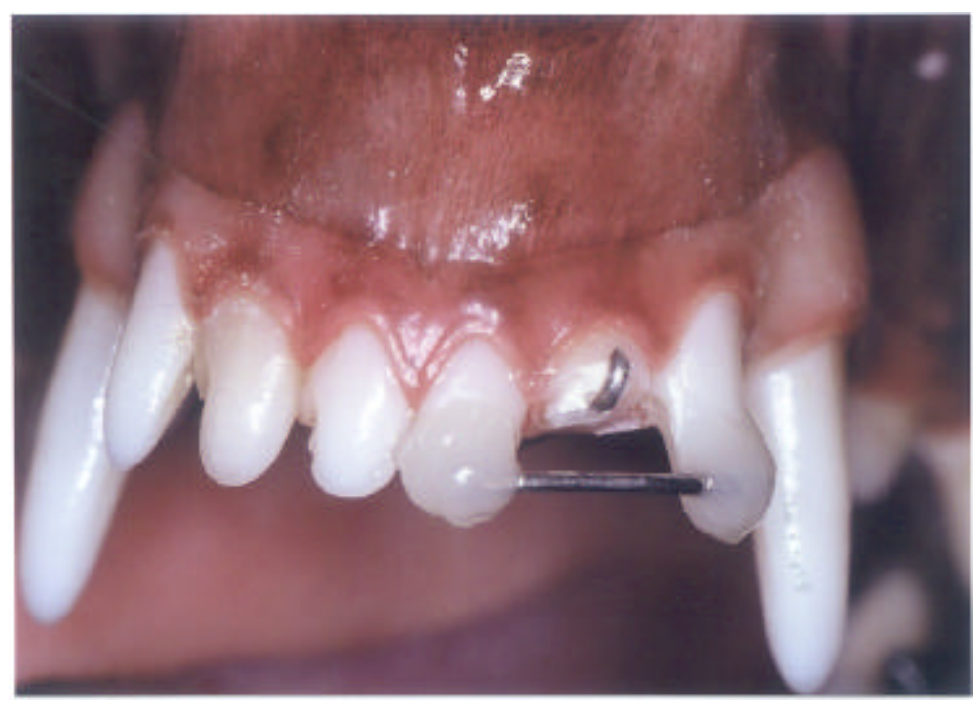

Figura 2 - Desgaste da coroa dentária no nível cervical e confecção dos aparatos para tração coronal ortodôntica do dente controle. 
Durante o período da movimentação dentária, o elástico em cadeia foi renovado semanalmente até o dente alcançar a ancoragem transversal.

O período de tempo para a tração completa destes $3 \mathrm{~mm}$ variou de 3 a 4 semanas. Após atingir o objetivo da tração ortodôntica, o elástico foi mantido como meio de contenção por mais 2 meses ou até a coleta do material para avaliação histológica nos grupos selecionados para análise em períodos menores de tempo (figura 4).

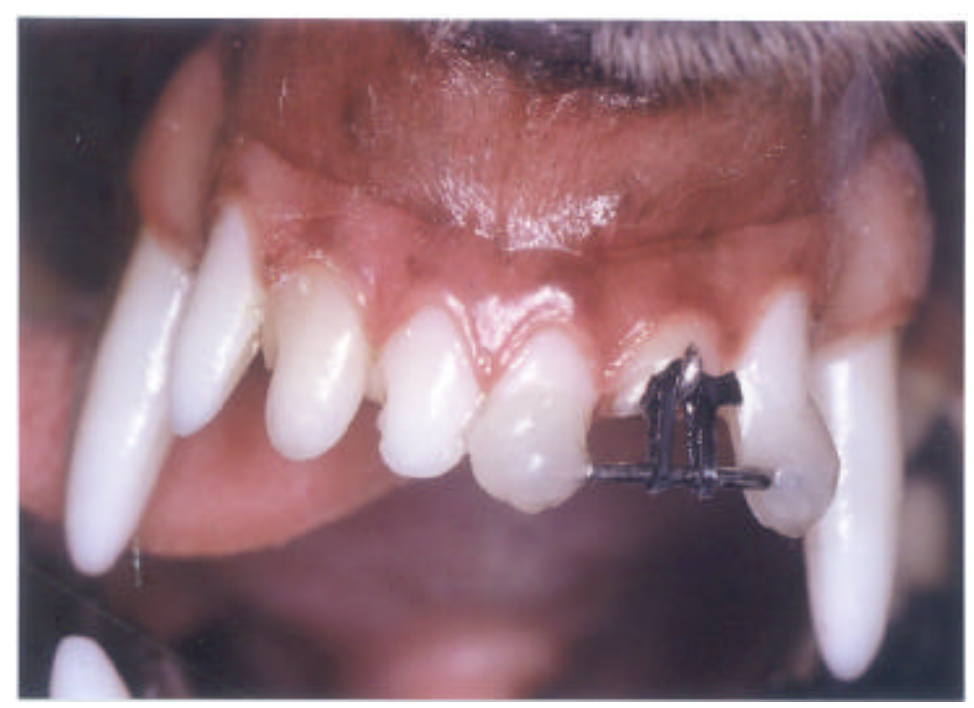

Figura 3 - Início da tração ortodôntica do dente controle. Observe que o elástico ortodôntico em cadeia permanece estirado em posição tal que produz a extrusão do dente. 


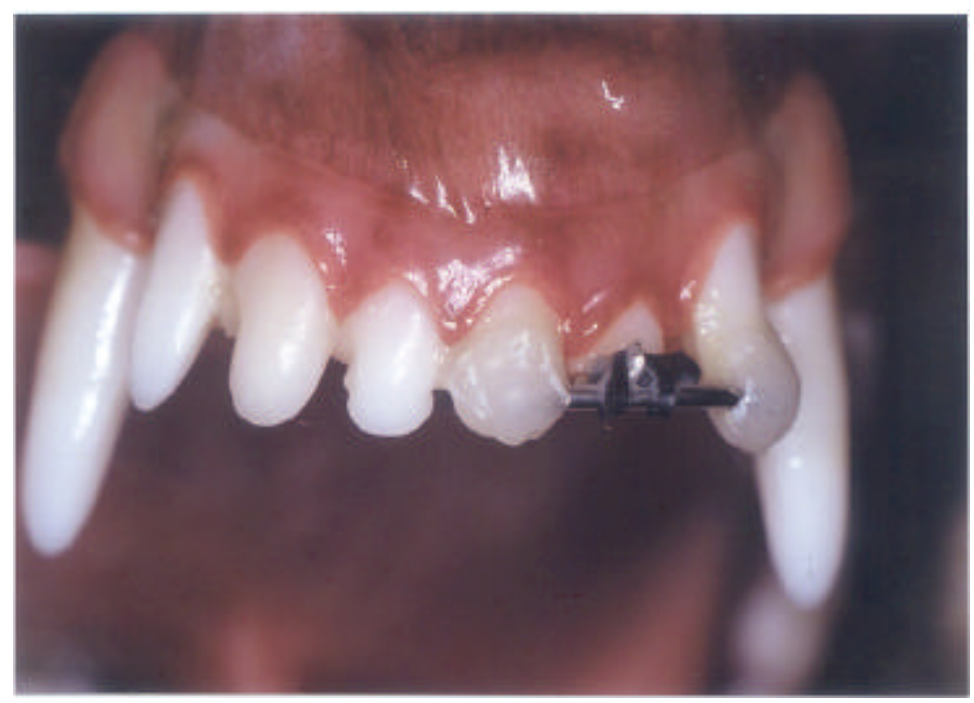

Figura 4 - Término da tração ortodôntica do dente controle. Veja que o dente encontra-se em contato com a ancoragem transversal, indicando 0 fim do movimento programado. É de se destacar, ainda, alguma mudança posicional da margem gengival, quando se compara com a figura anterior.

Somente após o término da tração ortodôntica o procedimento de extrusão cirúrgica foi realizado no outro dente. Assim foi definido porque os dentes tracionados ortodôntica e cirurgicamente apresentariam aproximadamente o mesmo grau de extrusão como ponto de partida para avaliação da cicatrização nos períodos pré determinados. Portanto, quando o movimento ortodôntico foi concluído, ou seja, no momento em que o dente alcançou o fio de contenção transversal, o procedimento de extrusão cirúrgica foi realizado no dente contralateral.

Para extrusão cirúrgica, inicialmente a coroa dentária também foi desgastada no nível cervical, usando ponta diamantada para obter a referência 
para a tração coronária da raiz (figura 5). Em seguida foi realizada a incisão intrasulcular e leve afastamento do tecido gengival. A luxação dentária foi realizada cuidadosamente com alavancas pediátricas para evitar fraturas de tábua óssea e o dente foi pinçado com fórceps pediátrico e também cuidadosamente extraído do alvéolo. Avaliação visual da raiz foi realizada para verificar eventual fratura radicular que pudesse inviabilizar o procedimento (figura 6).

Isto posto, o dente foi imediatamente reposto no alvéolo em posição aproximadamente $3 \mathrm{~mm}$ mais coronal, como ocorrera no lado oposto com o dente controle. A raiz foi então estabilizada somente por suturas interproximais interrompidas usando fio de seda 4,0 agulhado (Fio de sutura Ethicon - Johnson \& Johnson) e sem nenhuma esplintagem adicional. Somente por medida de segurança para que o dente não fosse exfoliado no período pós-operatório, foi confeccionado um aparato com fio de aço de $0,7 \mathrm{~mm}$ com finalidade de criar um apoio incisal para a raiz luxada; este dispositivo foi fixado com a resina composta na face vestibular do dente adjacente sendo mantido até o final do experimento (figura 7). 


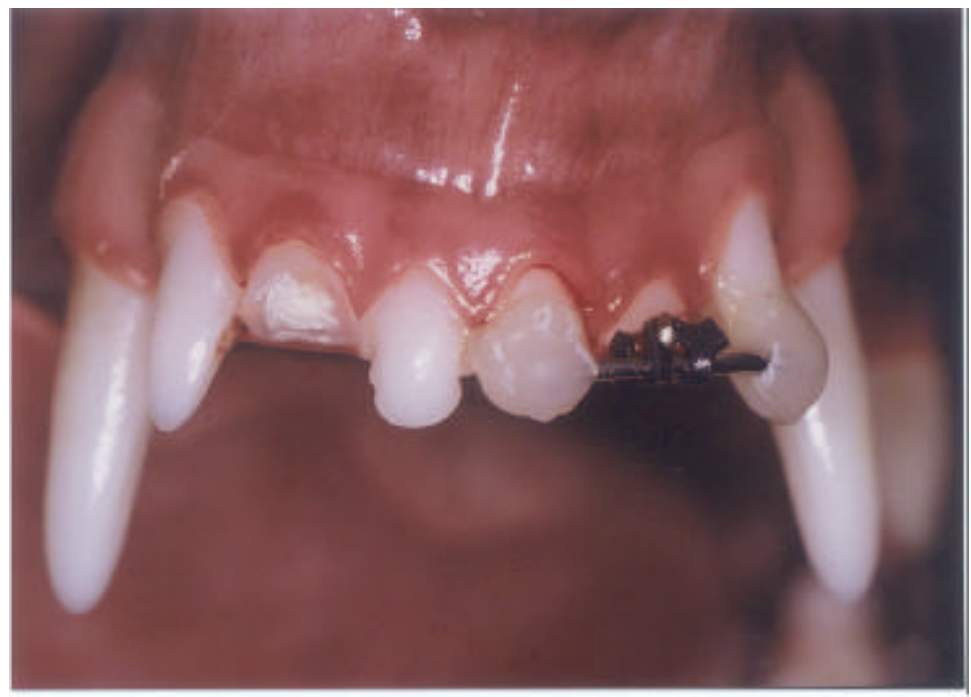

Figura 5 - Desgaste no nível cervical do dente experimental para obter a mesma referência do dente controle vista na figura 2 para aplicação do procedimento de extrusão cirúrgica.

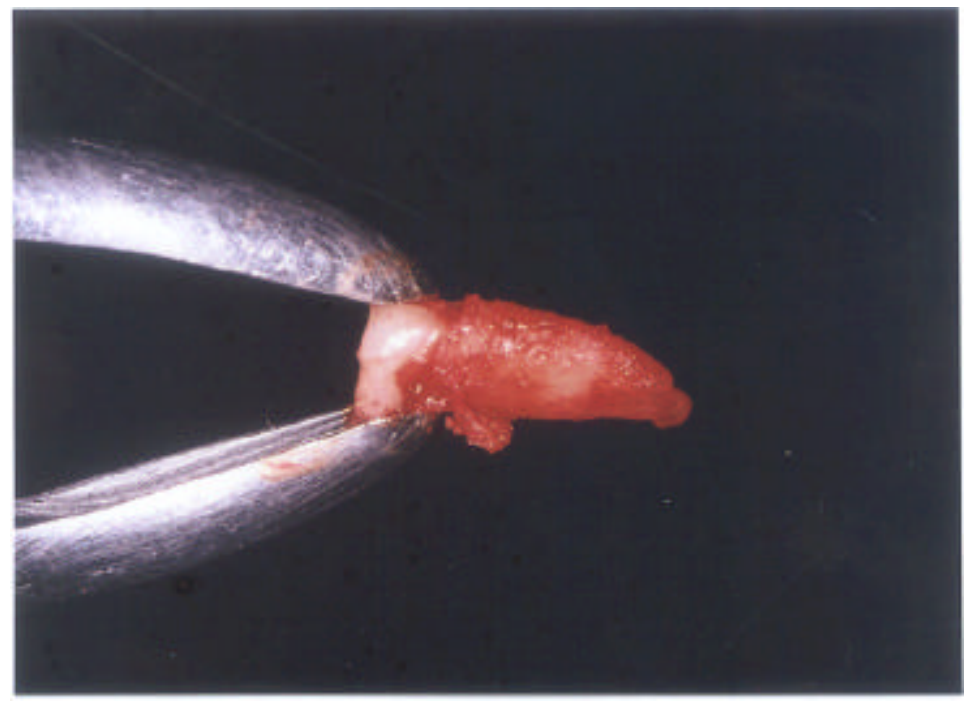

Figura 6 - O dente 12 extraído e visualizado. Observe a integridade da raiz com o ligamento periodontal intacto e sem toque ou manuseio sobre este. 


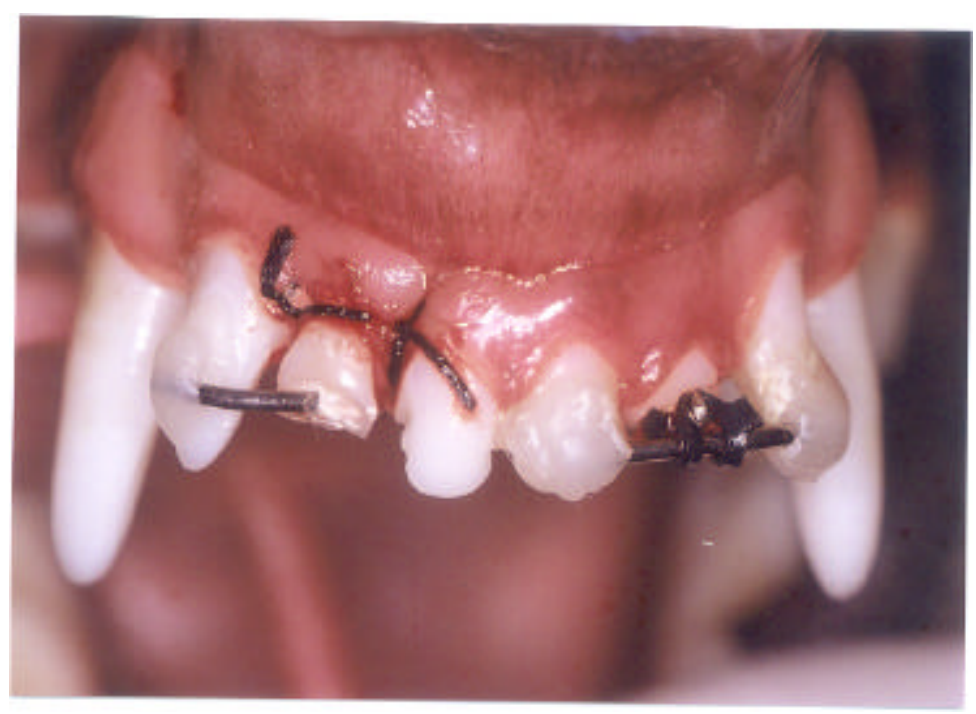

Figura 7 - Reposição do dente no alvéolo com extrusão de aproximadamente $3 \mathrm{~mm}$. Observe o aparato para apoio incisal do dente tracionado, fixado ao dente vizinho com resina composta.

Em situações nas quais os dentes sofreram fraturas durante 0 procedimento de extração, estes foram excluídos do estudo, porém, no mesmo animal utilizou-se um outro dente vizinho para o estudo, o incisivo central.

Após o procedimento cirúrgico todos os animais receberam dose única de 600.000 U.I. de Benzilpenicilina Benzatina (Penicilina G. Benzatina Ariston). Durante a primeira semana pós-operatória todos os animais foram mantidos em regime alimentar controlado com dieta pastosa. Ainda, por motivo de segurança, durante as duas primeiras semanas todos os animais foram mantidos com a adaptação de um colar Elizabetano ${ }^{49}$. Todos os animais receberam os cuidados de antissepsia local com a solução de clorexidina a 0,2 \% semanalmente. 


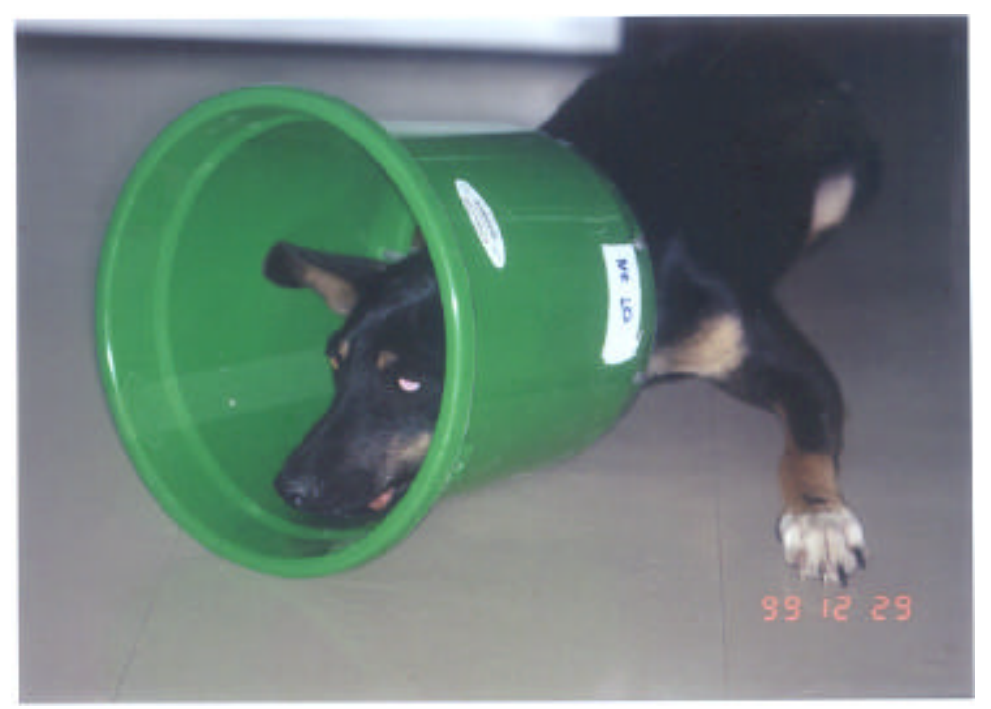

Figura 8 - Animal mantido com o colar Elizabetano adaptado para evitar o trauma físico pela aplicação das patas dianteiras nas primeiras semanas.

4. Avaliação

Os períodos de avaliação dos dentes controle (extrusão ortodôntica) e dentes experimental (extrusão cirúrgica) foram:

- grupo I - 7 dias

- grupo II - 14 dias

- grupo III - 45 dias

- grupo IV - 90 dias

- grupo V-120 dias

- grupo VI - 180 dias. 
5. Coleta das peças e processamento histológico

Decorridos os períodos determinados, os animais foram sacrificados utilizando uma overdose de anestésico e então foram obtidos os blocos de tecido contendo tecido gengival e osso alveolar junto com os dentes experimentais. As peças removidas foram mantidas em solução de formol tamponado a $10 \%$ por 72 horas, lavadas em água corrente por 24 horas e descalcificadas em solução de MORSE ${ }^{59}$.

As peças receberam o tratamento de rotina, isto é, lavagem, desidratação, diafanização e inclusão em parafina no sentido do longo eixo do dente, de forma que permitissem a microtomia no sentido transversal ao longo eixo do dente com espessura de 6 micrômetros.

A partir do segmento intra-alveolar, as raizes dos dentes experimentais foram divididas em 3 partes: terço coronal, terço médio e terço apical. De cada terço da raiz foram obtidos 4 cortes histológicos e as lâminas obtidas foram coradas pela técnica da hematoxilina - eosina para avaliação.

6. Análise dos resultados

Procedeu-se à descrição topográfica dos fenômenos histológicos observados na superfície da raiz e nas estruturas periodontais adjacentes: ligamento periodontal, cemento e osso alveolar nos terços coronal, médio e apical. 
Para essa análise, baseourse nos eventos histológicos das reabsorções radiculares externas classificadas de acordo com ANDREASEN ${ }^{15}$ em:

1) Reabsorção ativa de superfície, isto é, a cavidade de reabsorção está presente na superfície da raiz, confinada por periodonto normalmente estruturado; o processo de reabsorção ocorre na presença de células gigantes multi-nucleadas, mas sem infiltrado inflamatório;

2) Reparação da reabsorção de superfície, isto é, a cavidade de reabsorção do item anterior está reparada ou revestida por nova camada de cemento celular ou acelular;

3) Reabsorção ativa inflamatória, isto é, a cavidade de reabsorção na superfície da raiz é decorrente de células gigantes multi-nucleadas, na presença de infiltrado inflamatório;

4) Reparação da reabsorção inflamatória, isto é, a cavidade de reabsorção do item anterior está reparada ou revestida por nova camada de cemento celular ou acelular, porém o infiltrado inflamatório ainda está presente;

5) Reabsorção por substituição ou ancilose, isto é, a cavidade de reabsorção na superfície da raiz está presente e recoberta por deposição óssea, sendo vistas células gigantes multi-nucleadas na cavidade de reabsorção e as lamelas ósseas estão depositadas diretamente sobre a superfície do cemento e da dentina. 
Para caracterizar os diferentes graus destes eventos histológicos de reabsorção radicular, usourse o índice de KNIGHT, GANS e CALANDRA ${ }^{50}$ graduado em :

1. Discreto, quando um quarto da superfície da raiz ou dos tecidos circunjacentes foi envolvido;

2. Moderado, quando dois quartos da raiz ou tecidos circunjacentes foram envolvidos;

3. Intenso, quando três quartos da superfície da raiz ou dos tecidos circunjacentes foram envolvidos como mostra o esquema da figura 09.

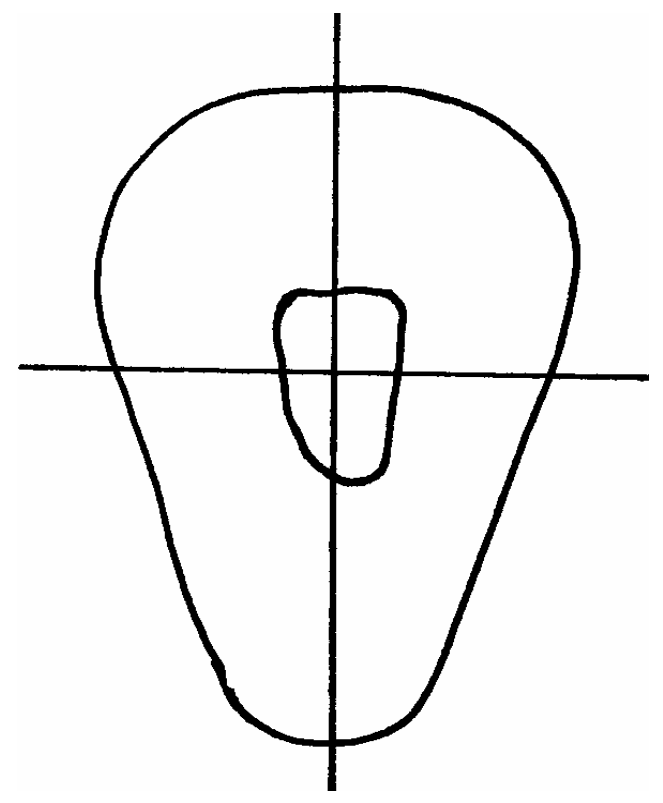

Figura 09 - Perímetro de raiz dividido em quatro partes para graduação da intensidade dos eventos de reabsorção radicular externa. 
5. RESULTADOS 


\section{5 - RESULTADOS}

EXTRUSÃO CIRÚRGICA : Grupo de 7 dias (figuras 11, 12, 13, 14, 15, 16, 17, 18)

\section{Terço coronal}

Nesta região observou-se o contorno normal da raiz, sem solução de continuidade da camada cementária e sem sinal de reabsorção da superfície radicular.

O espaço do ligamento periodontal mostrou irregularidade e espessamento com ruptura de fibras colágenas da porção intermediária do ligamento periodontal que levaram à degeneração das mesm as. A porção do ligamento remanescente adjacente ao dente mostrou ser densa e inserida por fibras colágenas com predominância de fibroblastos. Neste local a inserção de fibras perpendiculares ao cemento mostrou aparência normal quando comparado ao dente adjacente normal.

O ligamento periodontal no geral apresentou-se pouco denso devido àruptura das fibras colágenas e degeneração das mesmas. Os locais de ruptura apresentaram-se permeados por infiltrado inflamatório crônico intenso com muitos linfócitos, macrófagos e alguns neutrófilos difusos, visualizando-se ainda a presença de coágulo. A proliferação vascular foi intensa ao redor de todo o ligamento periodontal com vasos de diferentes calibres.

A reabsorção da superfície óssea mostroutse ativa com diversas lacunas de Howship e muitas celulas gigantes multinucleadas. 
Restos epiteliais de Malassez foram encontrados regularmente no ligamento periodontal remanescente adjacente àsuperfície radicular.

\section{Terço médio}

O espaço periodontal apresentou ausência de uniformidade em relação a sua largura ao redor da raiz, havendo locais mais amplos e outros mais estreitos. Não houve solução de continuidade da linha de cemento em todo perímetro da raiz, nem sinais de reabsorção da superfície radicular.

A maior parte do ligamento periodontal adjacente àraiz apresentou se normal, exibindo fibroblastos entremeados em tecido conjuntivo colagenoso. Todavia, na sua porção intermediária o ligamento periodontal mostrou degeneração de fibras colágenas, devido à ruptura das mesmas e destacando se, também, o extravasamento de hemácias. Observou-se infiltrado inflamatório crônico intenso com predominância de linfócitos, macrófagos e alguns neutrófilos difusos, além de intensa vascularização ao redor da raiz.

Nas superfícies ósseas observou-se ligamento periodontal remanescente, porém foi identificada atividade intensa de reabsorção com presença elevada de osteoclastos em toda sua extensão.

A presença de restos epiteliais de Malassez no ligamento periodontal adjacente àraiz foi achado freqüente.

\section{$\underline{\text { Terço apical }}$}

Inserção de fibras colágenas com disposição normal perpendicular foi observada em toda extensão das superfícies radiculares e nas paredes 
ósseas alveolares. Na porção intermediária do ligamento periodontal muitas áreas permaneceram com ruptura. Neste local, os feixes de fibras colágenas sofreram degeneração, mostrando-se esparsos próximo ao coágulo remanescente e permeados por células inflamatórias crônicas com predominância de linfócitos, macrófagos e também por neutrófilos difusos. Vascularização intensa foi observada em toda região do ligamento periodontal.

Em algumas áreas específicas o restabelecimento dos feixes de fibras colágenas entre o dente e o osso alveolar foi observado. Nestas áreas, o ligamento periodontal embora espessado apresentou feixes de fibras colágenas e fibroblastos em grande quantidade e sem alterações significativas. Os feixes de fibras colágenas eram mais evidentes do que na região cervical, porém quando comparado com o dente adjacente ainda estavam esparsos.

No geral, o perímetro da raiz apresentourse íntegro, porém ocorreu discreta solução de continuidade na camada cementária, com identificações de pequenas cavidades de reabsorção em nível de cemento e próximo das quais foram observadas fibras colágenas aparentemente normais.

Apesar da presença de muitas lacunas de reabsorção óssea e grande quantidade de células gigantes multinucleadas, a presença contínua de fibroblastos adjacentes àsuperfície óssea foi observada con stantemente. 
Gráfico 1 - Tipos e graus de reabsorção e reparação.

Médias do período -7 dias

Extrusão Cirúrgica

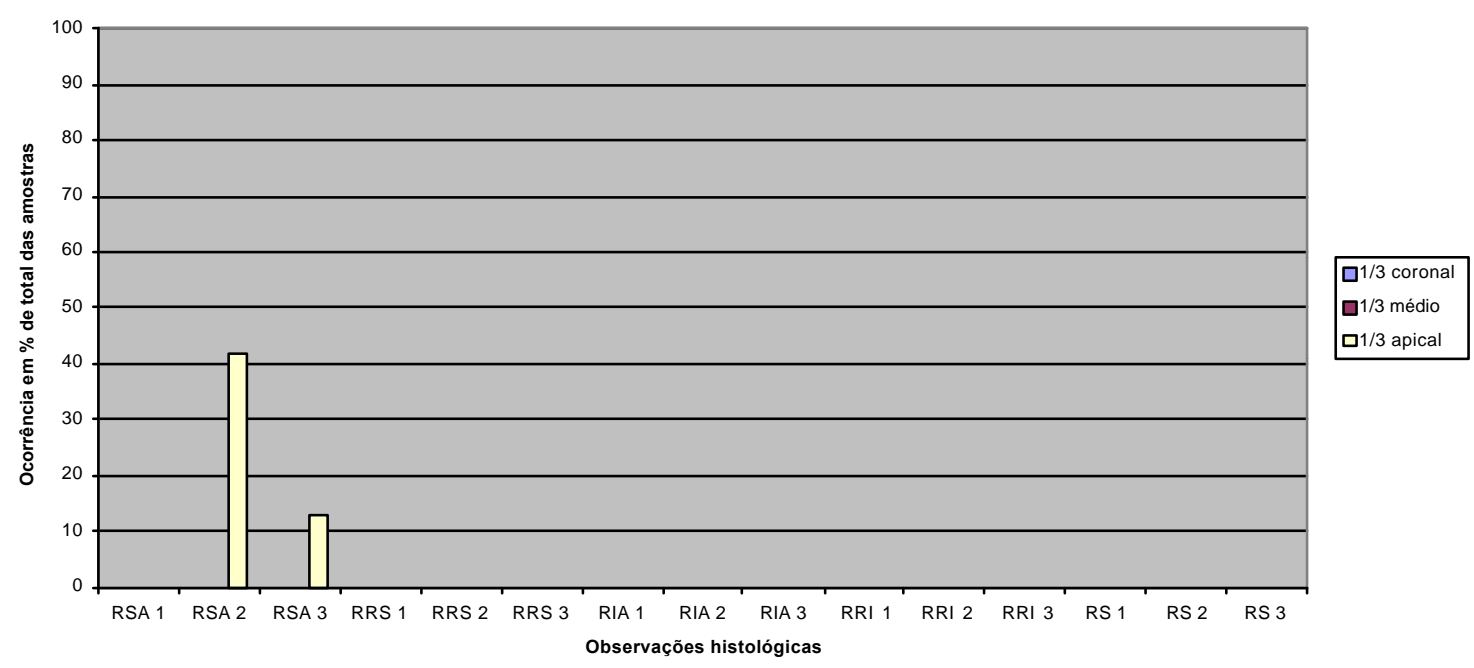

RSA - reabsorção ativa de superfície

RRS - reparação da reabsorção de superfície

RIA - reabsorção ativa inflamatória

$R R I$-reparação da reabsorção inflamatória

RS - reabsorção por substituição ou ancilose 
EXTRUSÃO ORTODÔNTICA : Grupo de 7 dias (figuras 19, 20,21)

\section{Terço coronal}

O ligamento periodontal apresentou maior espessamento e observourse tecido conjuntivo denso com feixes de fibras colágenas entremeados por fibroblastos e rico em vasos sanguíneos de diferentes calibres. Observourse ainda espaçamento uniforme em toda extensão da superfície radicular e as fibras colágenas adaptaram-se àdemanda fisiológica.

Houve a manutenção da integridade das fibras de Sharpey e proliferação fibroblástica foi observada em todo ligamento periodontal junto às superfícies radiculares e do osso alveolar. Não foi observada ruptura das fibras de Sharpey como ocorrera no lado experimental.

Não foi observada a solução de continuidade ao redor do perímetro da raiz; a camada de cemento apreceu intacta, com presença de fibras colágenas perpendiculares. A presença dos restos epiteliais de Malassez foi constante no ligamento periodontal ao redor da superfície radicular.

Nas superfícies ósseas houveram pequenas reabsorções com a presença de células gigantes multinucleadas e não foi observado infiltrado inflamatório em todo ligamento periodontal.

\section{Terço médio}

O ligamento periodontal mostrou-se normal com leve espessamento em relação ao ligamento do dente adjacente, porém os feixes de fibras colágenas 
evidenciaram-se densos, com proliferação fibroblástica intensa em todo ligamento periodontal.

Não houve sinais de ruptura do ligamento periodontal e de solução de continuidade do cemento. A presença dos restos epiteliais de Malassez foi constante no ligamento periodontal próximo àsuperfície radicular.

A superfície óssea mostroutse irregular e em algumas áreas exibiram atividade de reabsorção discreta, exibindo células gigantes multinucleadas dentro ou próximo æ̀s lacunas de Howship.

\section{Terço apical}

O ligamento periodontal mostrou-se alargado na maior parte da extensão radicular e preenchido por tecido conjuntivo denso. A densidade do colágeno pareceu ser menor quando comparado ao ligamento periodontal do dente adjacente, porém a proliferação fibroblástica e angioblástica foram intensas. Não foram observados sinais de ruptura das fibras colágenas nesta região.

O perímetro da raiz manteve a camada de cemento celular espesso e funcional com ausência de reabsorção na sua superfície. Células epiteliais dos restos de Malassez foram comumente observadas na intimidade com a superfície da raiz.

Nas superfícies ósseas houve discreta atividade de reabsorção e poucos osteoclastos. 
Gráfico 2 - Tipos e graus de reabsorção e reparação.

Médias do período - 7 dias

Extrusão Ortodôntica

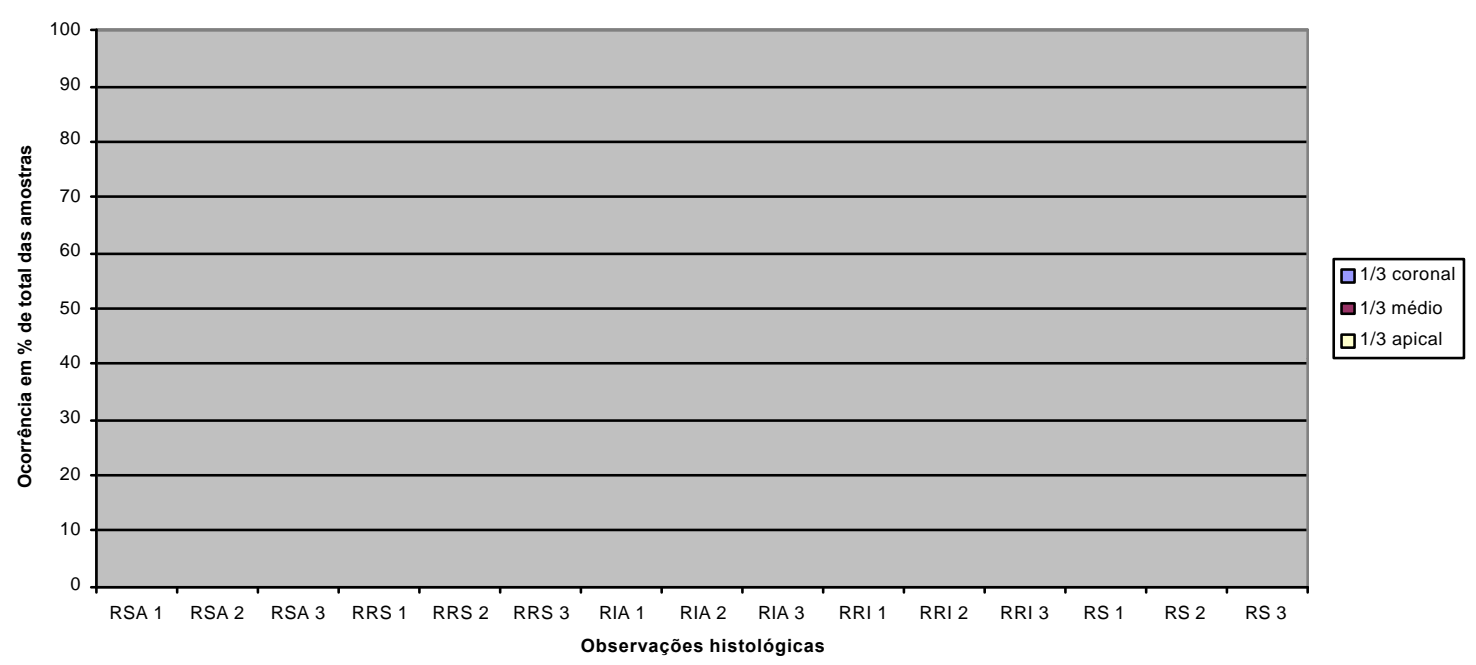

EXTRUSÃO CIRÚRGICA: Grupo de 14 dias (figuras 22, 23, 24, 25, 26, 27, 28, 29)

\section{Terço coronal}

O contorno da raiz mostroutse normal na maioria do grupo sem solução de continuidade. Porém em algumas amostras a continuidade foi rompida pela presença de lacunas de reabsorção radicular, identificando-se reabsorção de superfície e reabsorção inflamatória de discreta a moderada. A reabsorção de superfície comprometeu a camada de cemento e invadiu a dentina superficialmente, com a presença de célula gigante multinucleada junto à cavidade de reabsorção. No local da reabsorção inflamatória, o infiltrado inflamatório intenso e as células clásticas estiveram presentes junto à lacuna de reabsorção na dentina.

O ligamento periodontal mostrou-se em geral espessado e bastante irregular e em algumas áreas descontínuo. De forma geral o ligamento 
periodontal mostrourse restabelecido entre a parede óssea e a raiz. Observoutse proliferação fibroblástica intensa, embora a quantidade e densidade das fibras colágenas tenham se mostrado inferiores quando comparadas com o dente adjacente. Os restos epiteliais de Malassez não sofreram modificações na sua distribuição no ligamento periodontal.

O tecido conjuntivo do ligamento periodontal apresentou infiltrado inflamatório discreto com predominância de linfócitos, macrófagos, e alguns neutrófilos difusos. Este infilltrado foi encontrado principalmente subjacente à área onde houve ruptura do ligamento periodontal, com extravasamento de hemácias e degeneração do colágeno.

Áreas de reabsorção na superfície óssea foram observadas esporadicamente com a presença de osteoclastos junto às lacunas de Howship.

\section{Terço médio}

O ligamento periodontal apresentou-se restabelecido na sua maioria com a definição dos feixes de fibras colágenas, embora a sua espessura permaneceu maior e irregular. Em algumas áreas, o tecido conjuntivo apresentou-se com intensa proliferação fibroblástica e angioblástica.

O infiltrado inflamatório observado no ligamento periodontal foi crônico discreto com predominância de linfócitos e macrófagos, porém difuso. Isto foi encontrado em locais de ruptura do ligamento, ainda presente e com degeneração do colágeno. 
A integridade do contorno da raiz só foi interrompida pela reabsorção radicular de superfície discreta com pequenas lacunas de reabsorção no cemento observadas em poucas amostras.

A atividade de reabsorção óssea foi discreta com poucas células gigantes multinucleadas. Por outro lado, houve intensa atividade osteoblástica, com a formação de matriz osteóide e proliferação de fibroblastos adjacente à superfície óssea.

\section{Terço apical}

Foi encontrado o periodonto predominantemente normal ao redor de toda a raiz graduado em intenso, embora, a largura do ligamento periodontal não estivesse uniforme e mostrasse a espessura maior que o normal, o tecido conjuntivo mostrou-se organizado. No geral havia proliferação fibroblástica e angioblástica.

Foi encontrado discreto infiltrado inflamatório no ligamento periodontal em áreas de degeneração das fibras colágenas na zona intermediária do ligamento periodontal.

Pequeno fragmento ósseo isolado eventual foi encontrado dentro do ligamento periodontal

O perímetro da superfície do cemento esteve intacto com as fibras de Sharpey, não havendo solução de continuidade, nem reabsorção de raiz.

Atividade osteoclástica foi discreta na sua maioria, com exceção nos locais onde houve a diminuição da largura do ligamento periodontal ocorrendo a 
aproximação da raiz ao osso alveolar. Por outro lado, foi observado número elevado de fibroblastos adjacente æ̀s superfícies ósseas.
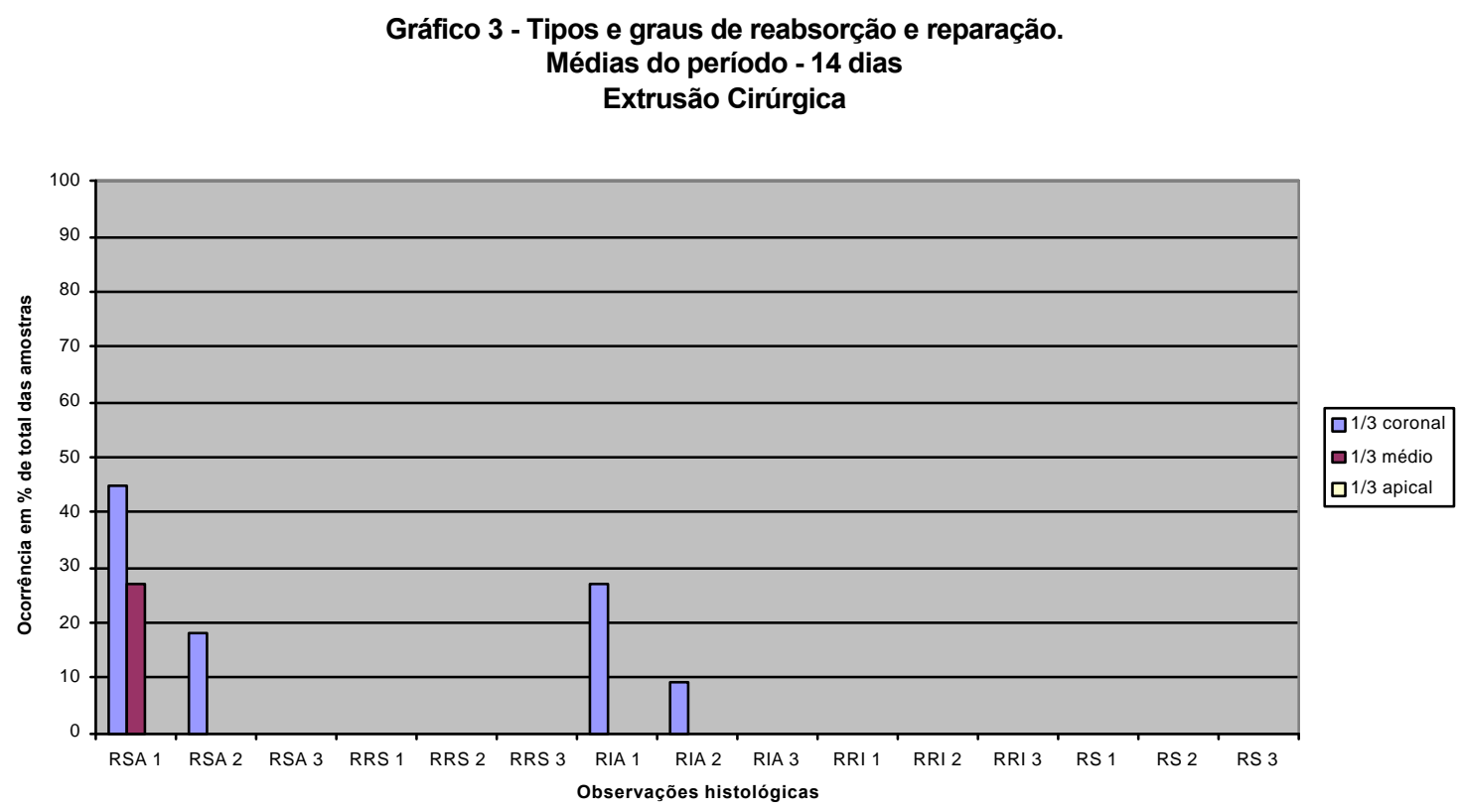

EXTRUSÃO ORTODÔNTICA : Grupo de 14 dias (figuras 30,31)

\section{$\underline{\text { Terço coronal }}$}

No geral o ligamento periodontal apresentou-se normal e organizado, apesar de discreto espessamento em relação ao dente vizinho, os feixes de fibras colágenas mostraram-se densos e bem definidos, não havendo sinais de ruptura. Infiltrado inflamatório não foi observado em todo o ligamento periodontal e a camada de cemento ao redor da raiz mostrou-se intacto e sem sinais de alteração por reabsorção. Ainda, os restos epiteliais de Malassez foram observados regularmente ao redor de toda a raiz. 
A remodelação fisiológica da estrutura óssea ocorreu normalmente com discreta atividade de reabsorção e poucos osteoclastos foram encontrados.

\section{Terço médio}

Poucas foram as alterações observadas no ligamento periodontal. A proliferação celular de fibroblastos e presença de colágeno denso e das fibras colágenas bem definidas puderam ser observados. A camada cementária íntegra apresentava inserção de fibras de Sharpey e as células epiteliais dos restos de Malassez faziam parte do ligamento periodontal adjacente àraiz.

Não foi observado nenhum infiltrado inflamatório no ligamento periodontal e na estrutura óssea ocorrera a remodelação fisiológica sem demonstrar qualquer tipo de alteração importante.

\section{$\underline{\text { Terço apical }}$}

Um dos animais apresentou infiltrado inflamatório crônico discreto no ligamento periodontal, predominantemente de linfócitos e macrófagos. Apesar disso, pôde-se observar no geral ligamento denso com grande quantidade de colágeno e proliferação celular. A estrutura do ligamento periodontal foi considerada normal comparando-se ao dente vizinho.

A estrutura radicular apresentou-se normal e não se observou qualquer tipo de reabsorção da superfície da raiz. Células epiteliais dos restos de Malassez marcaram presença constantes ao redor de toda a raiz. 
As fibras de Sharpey foram observadas inserindo perpendicularmente à raiz e à superfície óssea alveolar; os feixes de colágeno foram densos e bem definidos. As paredes ósseas mostraram remodelação normal, com poucas células multinucleadas presentes na sua superfície.

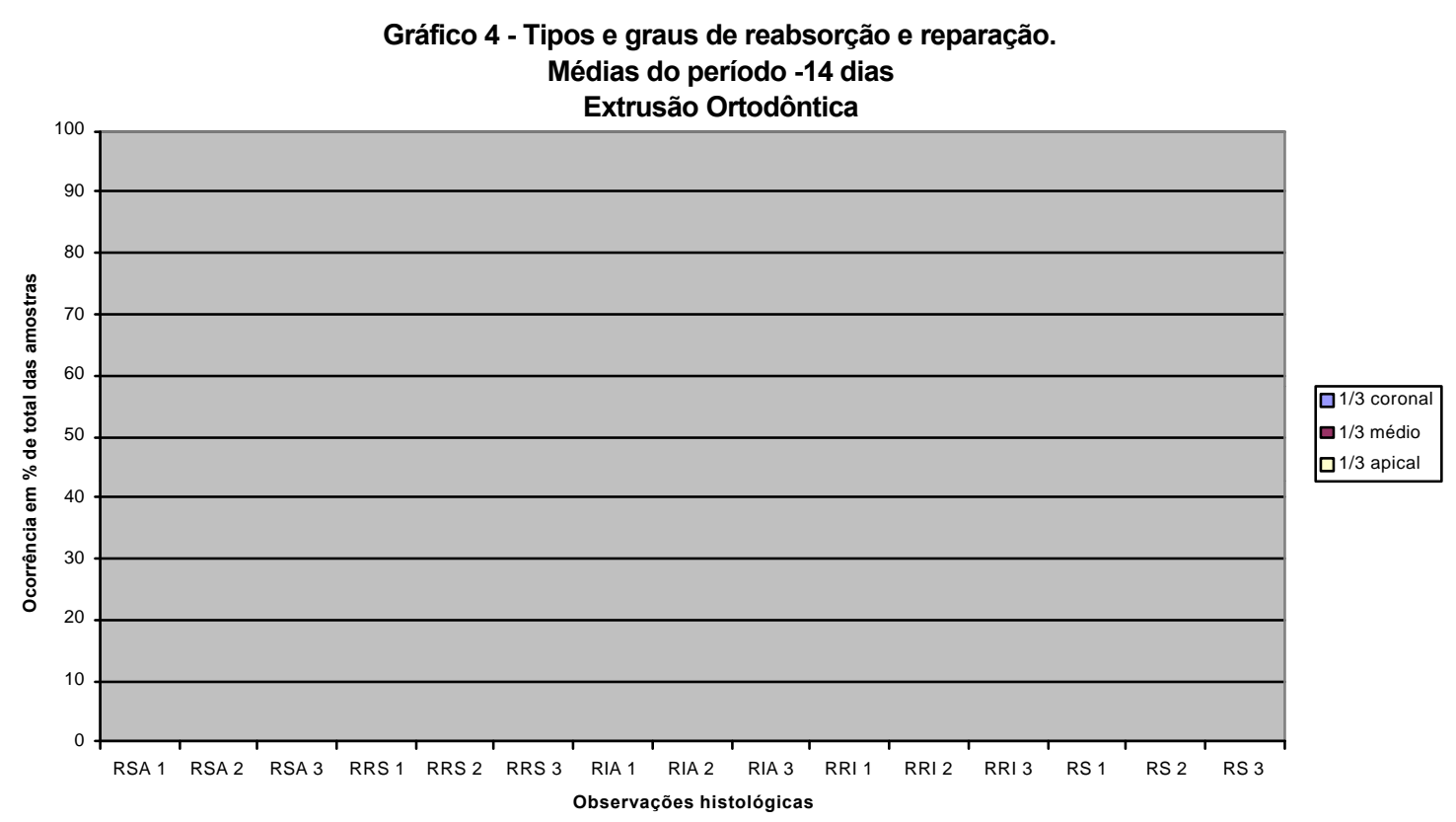

EXTRUSÃO CIRÚRGICA : Grupo de 45 dias (figuras 32, 33, 34, 35, 36)

\section{Terço coronal}

Periodonto normal e estruturado com ligamento periodontal denso e bem definido foi encontrado na maior parte ao redor do dente, porém mais espessado. Apesar do espessamento do ligamento periodontal e da variação da espessura do cemento comparado ao dente vizinho, tecido conjuntivo denso e inserido nas superfícies radiculares e ósseas foi observado em áreas que não 
sofreram qualquer tipo de reabsorção radicular. O tecido conjuntivo do ligamento periodontal apareceu organizado com a proliferação fibroblástica e vascular.

A reparação das cavidades de reabsorção de superfície discreta e moderada foi observada em áreas isoladas, apresentando nova formação de cemento, que recobriu a cavidade na dentina, como também houve reparação do ligamento periodontal nesta área. A reparação deste mostrou ser não funcional, pois as fibras estavam com disposição paralela à superfície do cemento reparado.

A solução de continuidade cementária ao redor do dente esteve presente em alguns espécimes. Eram cavidades de reabsorção de superfície ativa discreta localizadas no cemento, podendo-se observar célula gigante multinucleada junto à cavidade de reabsorção. Outra situação de solução de continuidade no cemento foi a presença de reabsorção inflamatória ativa discreta na dentina de alguns espécimes. Também foi possível observar reabsorção por substituição discreta em um espécime.

A remodelação do osso alveolar foi fisiológica; poucos osteoclastos foram encontrados nas superfícies ósseas revestidos linearmente por fibroblastos.

As células epiteliais foram observadas somente em locais de cemento e ligamento periodontal totalmente restabelecidos.

\section{$\underline{\text { Terço médio }}$}

O ligamento periodontal no geral apresentourse restabelecido com colágeno denso e uniforme. Apesar do seu espaço não ser uniforme ao redor de 
todo o dente, o ligamento periodontal apresentou normalidade funcional na sua maior parte.

Reparação das cavidades de reabsorção de superfície discreta a moderada foi encontrada nas amostras, havendo a formação de novo cemento e ligamento não funcional no local. Nesta área os restos epiteliais de Malassez não foram observados.

O contorno da raiz só foi rompido com solução de continuidade pela presença localizada da reabsorção inflamatória ativa em alguns espécimes, e também pela reabsorção por substituição moderada observada em poucas amostras. Apesar da ancilose localizada, no geral o osso alveolar apresentou remodelação funcional.

\section{$\underline{\text { Terço apical }}$}

O ligamento periodontal normalmente estruturado com fibras de Sharpey foi encontrado. A proliferação fibroblástica e vascular estava presente. A presença do infiltrado inflamatório foi localizada em poucos espécimes, porém sem comprometer a superfície radicular, sendo que o cemento e o ligamento periodontal permeneceram intactos.

Foi observada a reparação de reabsorção de superfície moderada no cemento e na dentina. Nestes locais o ligamento periodontal não era funcional, sendo a disposição das fibras colágenas paralelas àraiz e o colágeno pouco denso, não se observando presença de células epiteliais.

A remodelação óssea ocorreu normalmente e os osteoblastos revestiram sua superfície. 
Áreas localizadas de ancilose foram vistas em algumas amostras. Nestas áreas as células gigantes multi-nucleadas estiveram presentes próximas à raiz. Em locais de ancilose estabelecida não houve solução de continuidade entre o osso e o cemento.
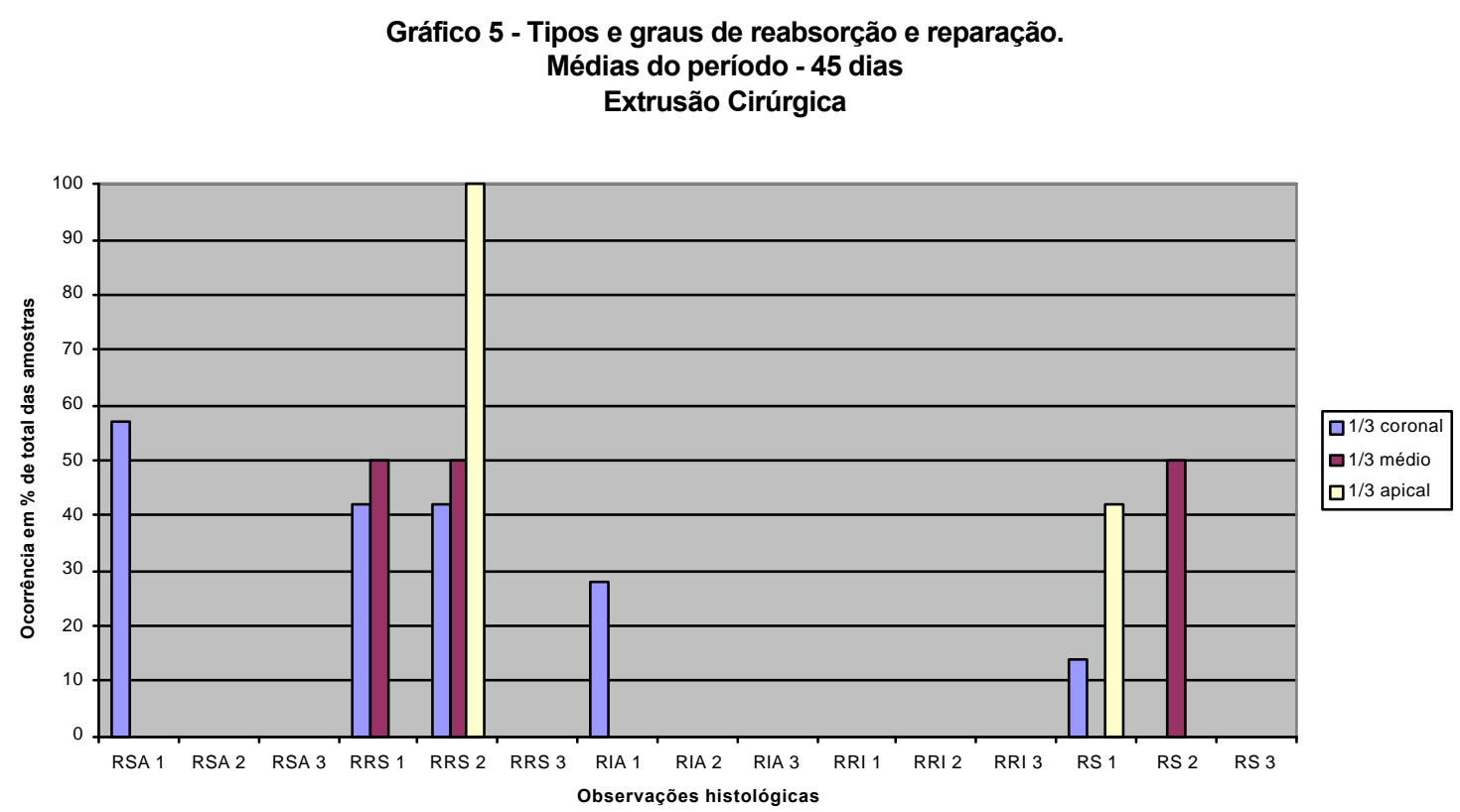

EXTRUSÃO ORTODÔNTICA : Grupo de 45 dias (figuras 37, 38, 39)

\section{Terço coronal}

O ligamento periodontal mostrourse inserido perpendicularmente à superfície do cemento; os feixes de fibras colágenas exibiram-se densos e funcionais, com exceção de locais isolados que sofreram reabsorção de superfície em cemento e dentina e que tiveram sua reparação apresentando disposição não funcional paralela àraiz. 
A largura do ligamento periodontal foi restabelecida quando comparada ao dente vizinho com o periodonto normal e a remodelação do ligamento periodontal e da superfície óssea apresentaram normalidade, com a presença contínua das células de revestimento. Células epiteliais dos restos de Malassez foram constantes no ligamento periodontal.

\section{$\underline{\text { Terço médio }}$}

O comportamento do ligamento periodontal neste segmento se igualou ao anterior. A observação de ligamento denso e funcional ao redor da raiz ocorreu. Em algumas amostras observoutse reparação das cavidades de reabsorção de superfície discreta a moderada em dentina e todas as reabsorções de superfície foram reparadas com novo cemento e fibroblastos na sua superfície, porém a disposição das fibras foi paralela àraiz.

Enquanto no ligamento periodontal restabelecido junto àraiz eram encontradas células epiteliais de Malassez, nas reparações de cemento com 0 ligamento não funcional não se observou a sua presença.

Não houve identificação da atividade de reabsorção radicular e de superfície óssea, a não ser pela remodelação fisiológica do periodonto.

\section{$\underline{\text { Terço apical }}$}

Os eventos histológicos neste segmento foram muito semelhantes aos anteriores. O ligamento periodontal apreceu na sua maioria denso e funcional, havendo poucas áreas de reparação de reabsorção de superfície localizada e com ligamento periodontal não funcional. 
Infiltrado inflamatório crônico foi encontrado isoladamente em algumas amostras. Observou-se áreas de degeneração do colágeno do ligamento periodontal, permeadas por células inflamatórias crônicas, porém sem alteração da superfície radicular no local.

No geral a remodelação óssea ocorreu normalmente e o espaço do ligamento periodontal foi uniforme e compatível com o dente vizinho normal.
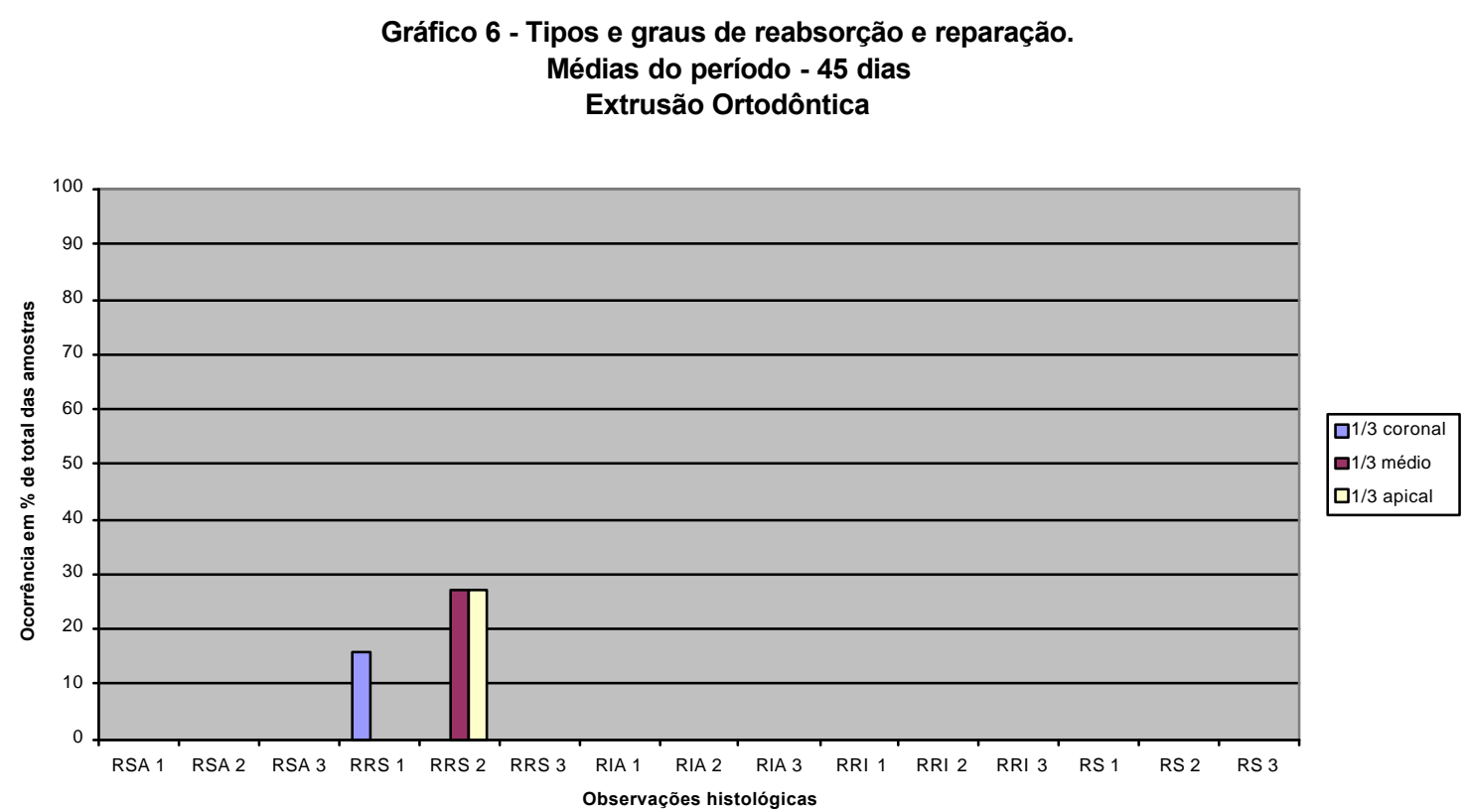

EXTRUSÃO CIRÚRGICA : Grupo de 90 dias $(40,41,42)$

\section{$\underline{\text { Terço coronal }}$}

O ligamento periodontal mostrou-se normal e funcional na maioria das amostras. As áreas de reparação de cavidades de reabsorção de superfície moderada e intensa na dentina exibiram ligamento periodontal pouco denso, e com disposição das fibras colágenas paralelas àsuperfície da raiz. Apesar disso, o ligamento não apresentou sinais de alteração inflamatória. Todas as cavidades 
de reabsorção radicular foram reparadas com novo cemento, porém a superfície da raiz mostrou-se irregular.

A proliferação de celulas foi intensa desde a superfície do cemento ao osso alveolar, podendo-se observar cementoblastos e osteoblastos enfileirados nestas respectivamente.

As células epiteliais de Malassez estiveram presentes somente em áreas com ligamento periodontal estruturado.

\section{Terço médio}

Periodonto normalmente estruturado entre o cemento e osso alveolar foi observado na maioria dos espécimes.

Áreas de reparação das cavidades de reabsorção de superfície moderada e intensa na dentina foram encontradas, associadas com ligamento periodontal não funcional também; nestas áreas não foram observadas células epitelias de Malassez, apenas presentes em áreas de ligamento periodontal estruturado e restabelecido.

A remodelação fisiológica óssea ocorreu em todas as amostras, com a presença contínua de células de revestimento superficial.

\section{$\underline{\text { Terço apical }}$}

Ligamento periodontal normal e estruturado alternou com áreas de infiltrado inflamatório crônico. A presença de células inflamatórias permeadas em área de degeneração das fibras colágenas foi isolada e ocupou pequeno espaço em todo o ligamento, sendo confinadas nos locais com canais secundários. No 
geral o ligamento apresentou densidade normal com disposição definida de fibras colágenas.

Todas as cavidades de reabsorção de superfície em dentina foram reparadas com novo cemento e presença de ligamento ainda não funcional, sendo que este evento variou de moderado a intenso. A inflamação crônica ainda esteve presente em áreas onde houve reparação da reabsorção inflamatória discreta em algumas amostras. Por outro lado, não foi encontrado nenhum tipo de reabsorção ativa nas amostras observadas.

A presença de células epiteliais dos restos de Malassez foram constantes junto ao ligamento periodontal funcional.

A remodelação óssea ocorreu normalmente, mantendo assim o espaço regular do ligamento periodontal.

Gráfico 7 - Tipos e graus de reabsorção e reparação.

Médias do período - 90 dias

Extrusão Cirúrgica

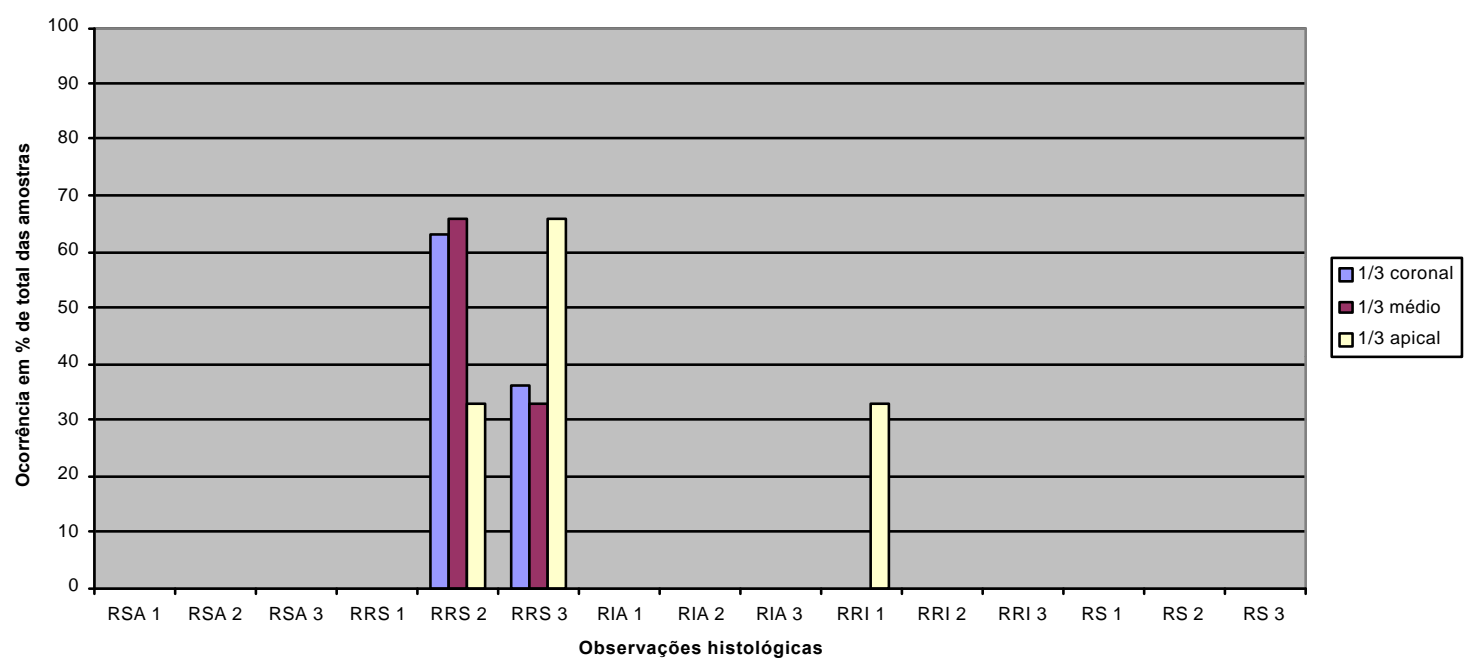


EXTRUSÃO ORTODÔNTICA : Grupo de 90 dias (figuras 43, 44, 45, 46)

\section{Terço coronal}

A largura do ligamento periodontal esteve regular em todo redor da raiz e preenchida por um colágeno denso e bem definido. Processo inflamatório não foi observado.

Não houve solução de continuidade no perímetro radicular e nenhum sinal de atividade de reabsorção da raiz.

Reparações de reabsorção de superfície moderada foram vistas. As cavidades de reabsorção na dentina foram recobertas pelo novo cemento e presença contínua de fibroblastos na sua superfície, porém o ligamento periodontal não se evidenciou funcional e sua aparência foi de frouxidão. Neste local células epiteliais de Malassez não foram observadas.

\section{Terço médio}

Ligamento periodontal normalmente estruturado foi encontrado em quase todas as amostras, exceto em alguns espécimes que apresentaram áreas de reparação das cavidade de reabsorção de superfície discreta. Nestes locais o ligamento mostrou-se não funcional, apesar da presença de novo cemento sobre a dentina e não se encontrou restos epiteliais de Malassez. Estes foram vistos somente em ligamento periodontal bem estruturado.

A remodelação do ligamento periodontal e do osso alveolar ocorriam fisiologicamente para manter largura normal do periodonto. 
$\underline{\text { Terço apical }}$

O ligamento periodontal apresentourse denso e definido com a presença de fibras de Sharpey na maior parte deste. Em algumas áreas, nas quais ocorreram reparações de cavidades de reabsorção de superfície discreta, o ligamento foi restabelecido e mostrou fibras colágenas com densidade normal, permeadas por fibroblastos. todavia, em outras áreas o ligamento não foi funcional, pois as fibras colágenas apresentaram disposição paralela à raiz e mostraram frouxidão do colágeno, não se encontrando as células epiteliais de Malassez. Apesar disso, nenhum processo inflamatório foi encontrado, a remodelação óssea esteve normal e manteve o espaço do ligamento periodontal comparado ao dente vizinho normal.

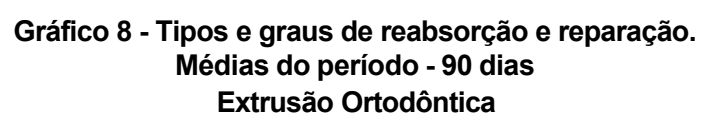

Extrusão Ortodôntica

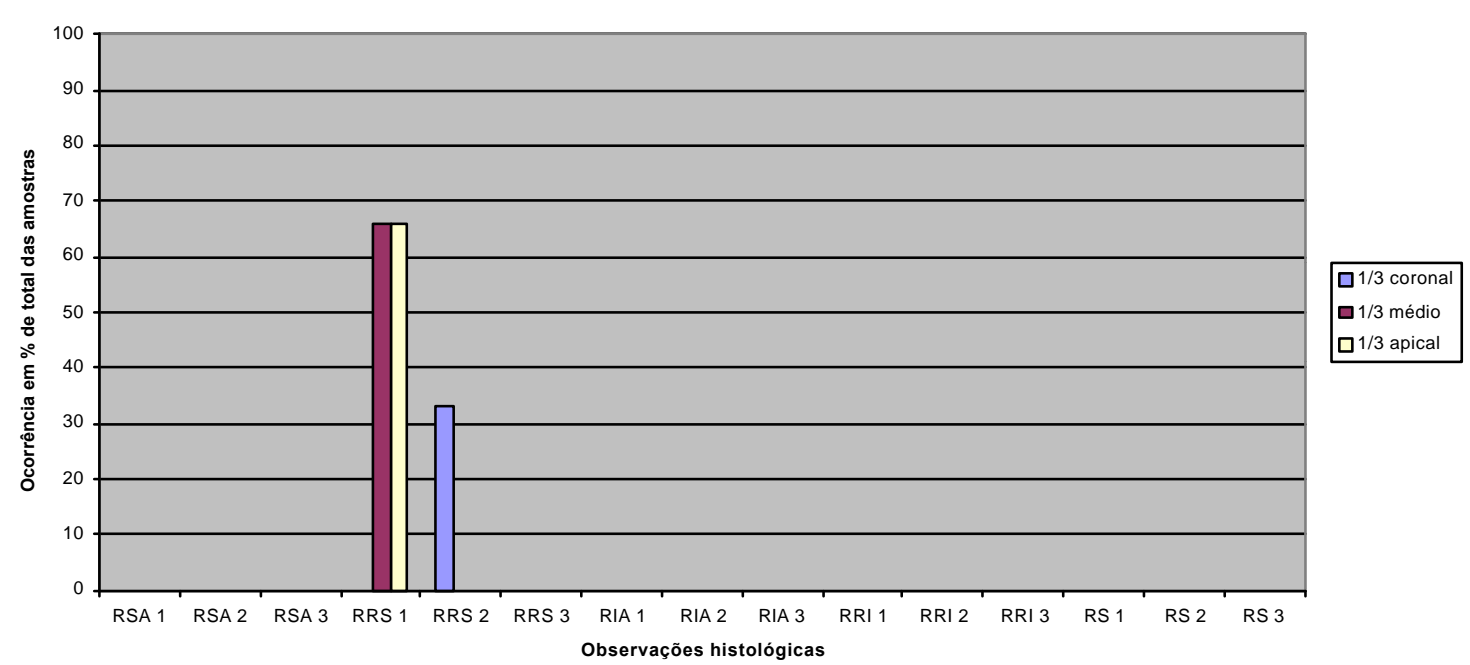


EXTRUSÃO CIRÚRGICA : Grupo de 120 dias (figuras 47, 48, 49)

\section{Terço coronal}

Em todas as amostras o ligamento periodontal esteve normalmente estruturado. A sua aparência foi similar àdo dente vizinho, com ligamento denso entremeado por fibroblastos e vasos sanguíneos. Apesar disso, o espaço deste foi irregular.

Não houve infiltrado inflamatório no ligamento periodontal e nenhuma atividade de reabsorção na superfície radicular e óssea, destacando-se remodelação fisiologica destas estruturas.

A raiz apresentou irregularidade no contorno, sendo observadas reparações de reabsorção de superfície moderada e intensa. As cavidades na dentina provocadas pelas reabsorção foram revestidas por novo cemento, porém com ligamento pouco denso, apresentando disposição paralela das fibras colágenas.

As células epitelias dos restos de Malassez somente foram econtradas em ligamento periodontal estruturado.

\section{$\underline{\text { Terço médio }}$}

Observações de ligamento periodontal normal e de áreas de reparação de cavidades de reabsorção foram semelhantes ao segmento anterior.

Áreas isoladas de ancilose foram vistas em poucas amostras. $O$ ligamento periodontal apresentou-se degenerado e ocupado pela proliferação do osso alveolar sobre a camada cementária. Em outras áreas próximas da ancilose, reabsorção óssea ocorreu parecendo restabelecer o espaço para o 
ligamento periodontal; foram identificadas células gigantes multi-nucleadas nesta superfície.

\section{$\underline{\text { Terço apical }}$}

Área isolada de infiltrado inflamatório crônico linfocitário foi encontrada no ligamento periodontal em algumas amostras.

Reparação das cavidades de reabsorção de superfície intensa em dentina foi observada; no entanto todas as cavidades de reabsorção foram reparadas com novo cemento celular ou acelular. A espessura do cemento reparado variou e o grau de colagenização sobre este cemento reparado também. Nos locais onde o cemento apareceu espesso, o ligamento periodontal esteve denso, enquanto que no cemento reparado delgado o mesmo não ocorreu.

Nas áreas da raiz que não sofreram alterações de cemento, foi observada presença de fibras de Sharpey bem definidas, enquanto que as áreas de reparação de reabsorções não apresentaram a mesma disposição das fibras.

Apesar do contorno irregular da raiz, a largura do ligamento periodontal foi restabelecida e observourse remodelação óssea fisiológica. 
Gráfico 9 - Tipos e graus de reabsorção e reparação. Médias do período - 120 dias

Extrusão Cirúrgica

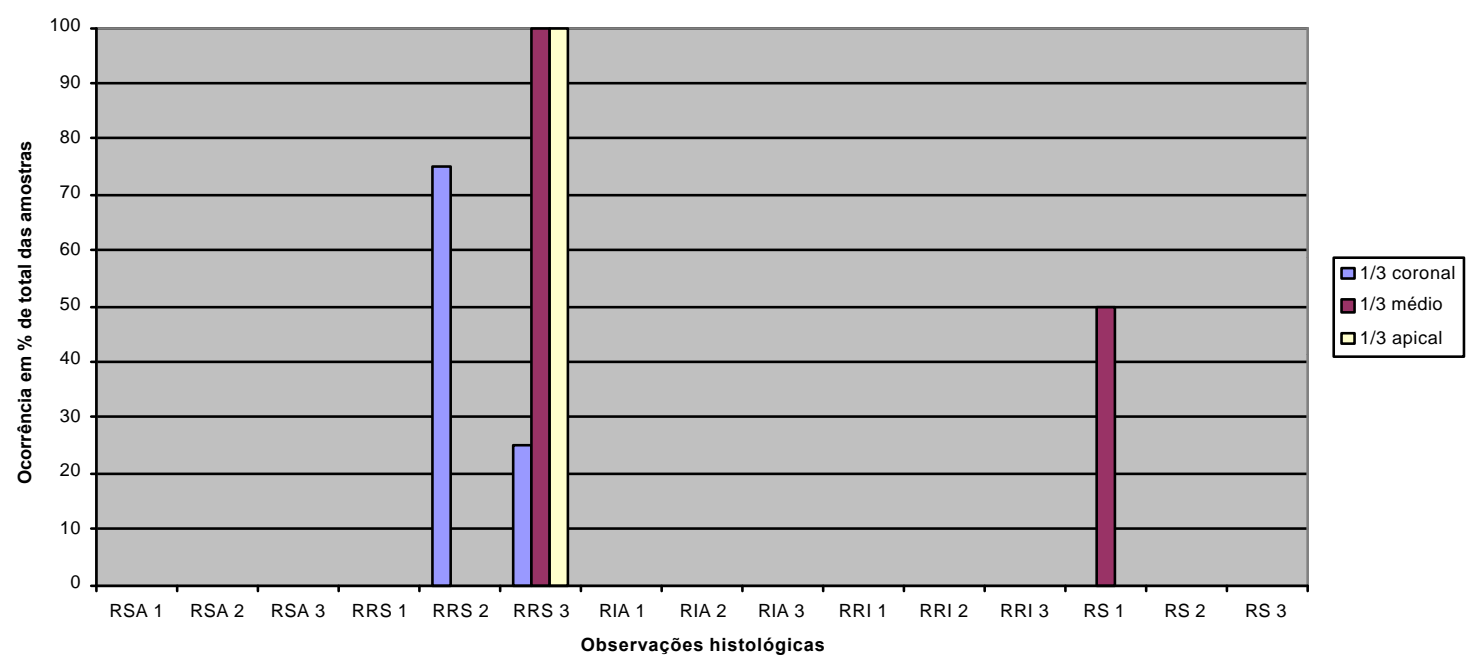

EXTRUSÃO ORTODÔNTICA : Grupo de 120 dias (figuras 50, 51, 52)

\section{Terço coronal}

Ligamento periodontal denso, definido e funcional foi observado. A sua largura esteve regular ao redor de toda a raiz.

Pequenas lacunas de reabsorção de superfície na dentina foram reparadas com novo cemento e ligamento periodontal, com densidade semelhante ao normal. Apesar disso, as células epiteliais dos restos de Malassez não foram vistas nestas áreas.

$\mathrm{Na}$ raiz não foi observada solução de continuidade da camada cementária e a remodelação óssea ocorreu normalmente. 
Terço médio

Todo o ligamento periodontal mostrourse denso e definido. As estruturas de cemento e osso alveolar mostraram fixação de feixes de fibras perpendiculares e a largura do ligamento periodontal esteve regular e uniforme.

Reparação das lacunas de reabsorção de superfície discreta foi encontrada na maioria das amostras e todas elas foram preenchidas com novo cemento e ligamento periodontal funcional, porém, mesmo assim, nestas áreas não foram observadas células epiteliais de Malassez.

Não houve infiltrado inflamatório no ligamento periodontal como também nenhuma solução de continuidade da camada cementária. Na superfície óssea alveolar ocorreu remodelação fisiológica.

\section{Terço apical}

As observações neste segmento foram semelhantes ao segmento anterior. Todo o ligamento periodontal apresentou colágeno denso e fibras de Sharpey bem definidas. A largura do espaço periodontal foi uniforme, acompanhada de remodelação óssea fisiológica.

A diferença em relação ao segmento anterior foi que as áreas de reparação de reabsorção de superfície foram graduadas em moderada e ainda localizadas somente no cemento. Entretanto, todas as cavidades de reabsorção foram reparadas com novo cemento e ligamento periodontal funcional. Apesar disso, não foram encontradas células epiteliais de Malassez. 
Gráfico 10 - Tipos e graus de reabsorção e reparação.

Médias do período - 120 dias

Extrusão Ortodôntica

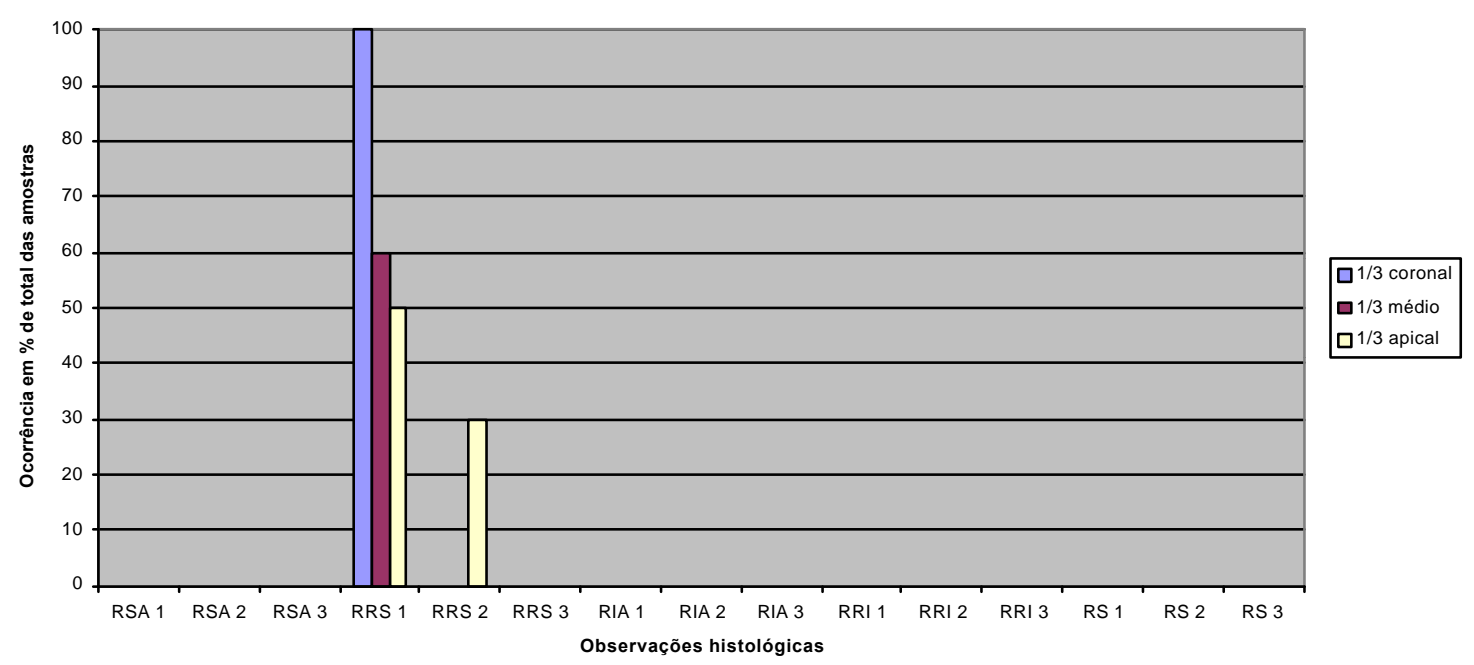

EXTRUSÃO CIRÚRGICA : Grupo de 180 dias (figuras 53, 54, 55, 56, 57)

\section{Terço coronal}

Em todas as amostras observou-se ligamento periodontal restabelecido e funcional. O colágeno apresentourse denso, com os feixes de fibras uniformes e direcionados.

Reparações extensas das reabsorções na dentina e no cemento foram vistas e compreendiam mais da metade do perímetro da raiz. A maioria das lacunas de reabsorção foram reparadas por novo cemento e com inserção de 
fibras colágenas perpendiculares, ou seja, um ligamento periodontal funcional. Outras áreas de reparação mostraram ligamento pouco denso e não funcional, cujas fibras colágenas apresentaram disposição paralela àraiz.

Apesar da presença do ligamento periodontal normal e estruturado entre a raiz e osso alveolar, o espaço deste não foi uniforme ao redor da raiz, que por sua vez também evidenciou-se toda irregular. Mesmo assim o osso alveolar manteve a remodelação fisiológica para a manutenção do espaço do ligamento periodontal.

Células epiteliais de Malassez não foram vistas em áreas de reparação das lacunas de reabsorção de superfície.

\section{Terço médio}

Observações neste segmento diferiram do anterior pela presença de área de reparação de reabsorção inflamatória discreta com a manutenção de pequeno infiltrado inflamatório crônico linfocitário no local. No local da reparação, junto àraiz observou-se presença de células de revestimento por fibroblastos e com colágeno pobremente estruturado e degenerado devido à presença de inflamação.

Em áreas de reparação de reabsorção de superfície foi visto ligamento periodontal restaurado, porém as células epiteliais de Malassez ainda não foram observadas.

Apesar da restauração do periodonto na sua maioria, a largura do ligamento esteve irregular. 
$\underline{\text { Terço apical }}$

Áreas de infiltrado inflamatório crônico linfocitário permeando o ligamento periodontal degenerado foram observadas nos locais próximos aos canais secundários em algumas amostras, porém não houve reabsorção radicular no local.

A raiz mostrourse toda irregular, como também a sua largura. Todavia, no geral observou-se ligamento periodontal normalmente estruturado e funcional, ocorrendo tanto nas áreas da raiz que não sofreram nenhum tipo de reabsorção radicular, como também em áreas onde houve reparação de reabsorção de superfície com cemento celular ou acelular; mesmo assim, células epiteliais de Malassez não foram encontradas.

Também foi observada a reparação de reabsorção inflamatória discreta em poucas amostras. As lacunas de reabsorções foram preenchidas com novo cemento e ligamento periodontal não funcional, mantendo ao seu redor infiltrado inflamatório crônico linfocitário. 
Gráfico 11 - Tipos e graus de reabsorção e reparação.

Médias do período - 180 dias

Extrusão Cirúrgica

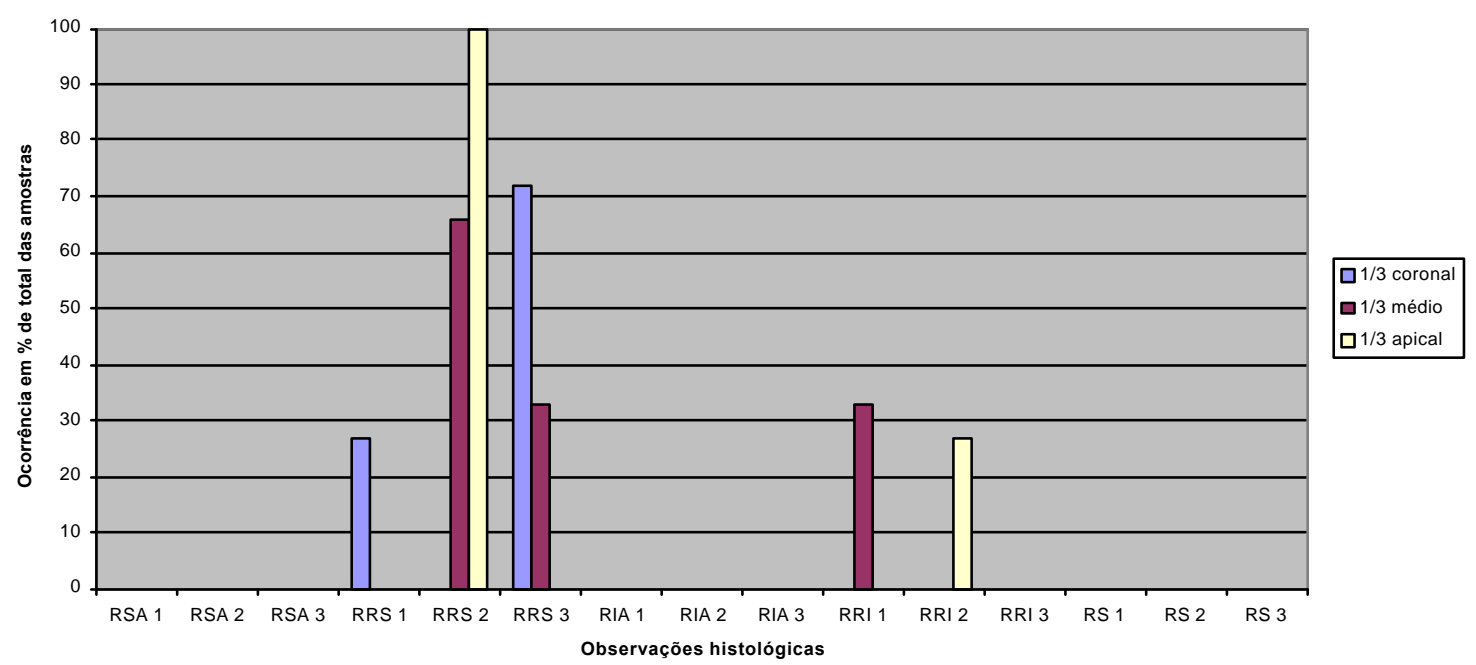

EXTRUSÃO ORTODÔNTICA : Grupo de 180 dias (figuras 58, 59, 60, 61)

\section{$\underline{\text { Terço coronal }}$}

Ligamento periodontal denso, uniforme e funcional foi encontrado na maioria das amostras, inclusive nas áreas de reparação de pequenas cavidades de reabsorção de superfície no cemento e na dentina.

Células epiteliais dos restos de Malassez foram constantes em todo o redor, menos em áreas de reparação da reabsorção radicular.

\section{$\underline{\text { Terço médio }}$}

Ligamento periodontal altamente celular e fibroso foi encontrado em todas as amostas, mesmo naqueles que tiveram reparação das lacunas de 
reabsorção de superfície. Todo o ligamento periodontal exibiu-se denso, uniforme e funcional e a sua largura foi regular e semelhante ao dente vizinho; apesar disso, células epiteliais não foram vistas em áreas de reparação de cemento e a remodelação óssea ocorreu normalmente.

\section{$\underline{\text { Terço apical }}$}

Pequenas áreas de reparação de reabsorção de superfície discreta foram observadas. O ligamento periodontal nestas áreas apareceu denso e funcional. Em todo o ligamento foram vistas feixes de fibras colágenas bem definidos e a sua largura foi uniforme ao redor de toda a raiz.

Nas superfícies ósseas foram observadas muitas células de revestimento e algumas células gigantes multinucleadas para sua remodelação.

Não huve inflamação no ligamento periodontal e nem mesmo a solução de continuidade da camada cementária; células epiteliais foram encontradas somente nas áreas que não sofreram nenhum tipo de reabsorção radicular. 
Gráfico 12 - Tipos e graus de reabsorção e reparação.

Médias do período -180 dias

Extrusão Ortodôntica

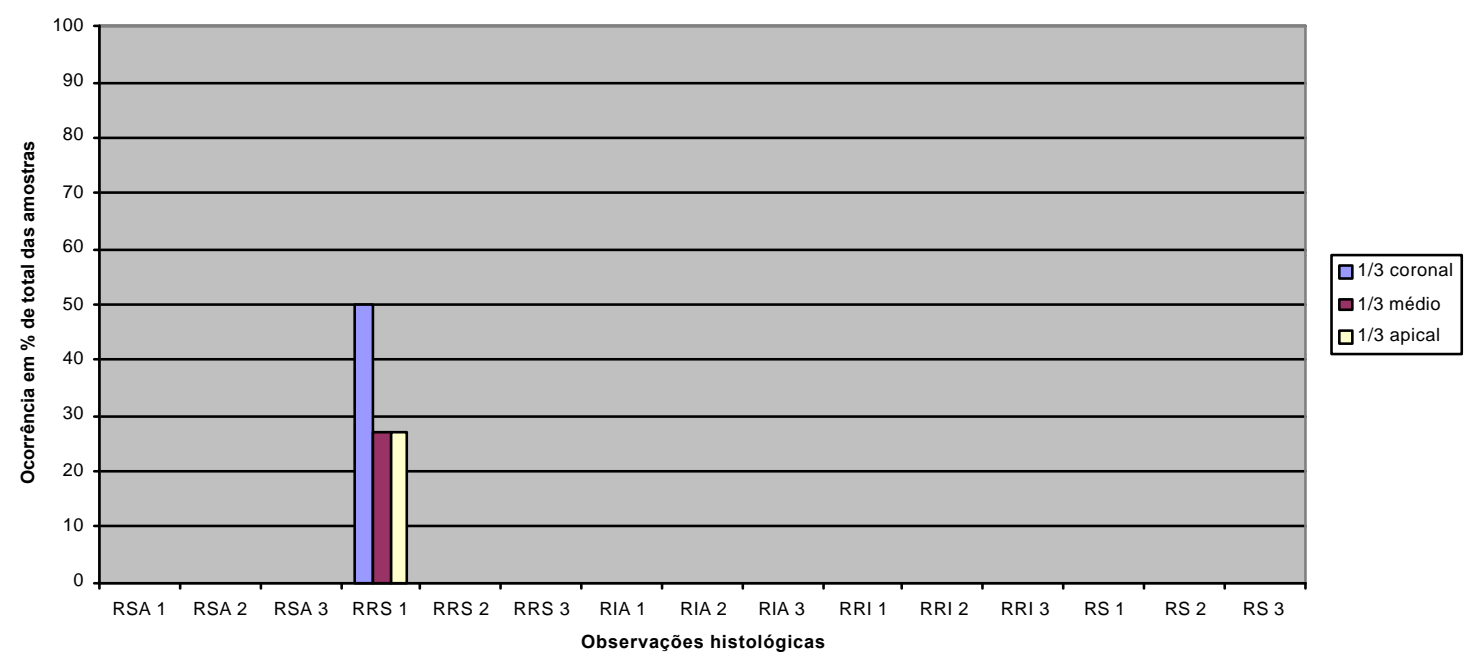




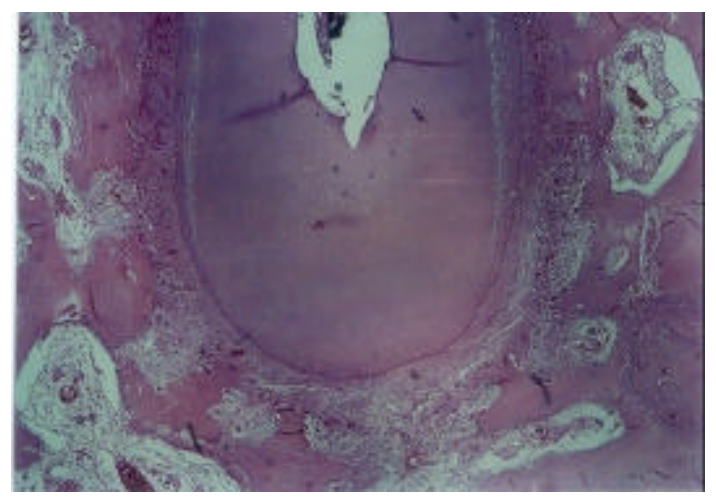

Figura 10 - Extrusão Cirúrgica, 7 dias, $1 / 3$ coronal. H.E. $4 \mathrm{X}$.

Largura do ligamento periodontal. irregular, sinal de ruptura na porção intermediária e manutenção da camada cementária.

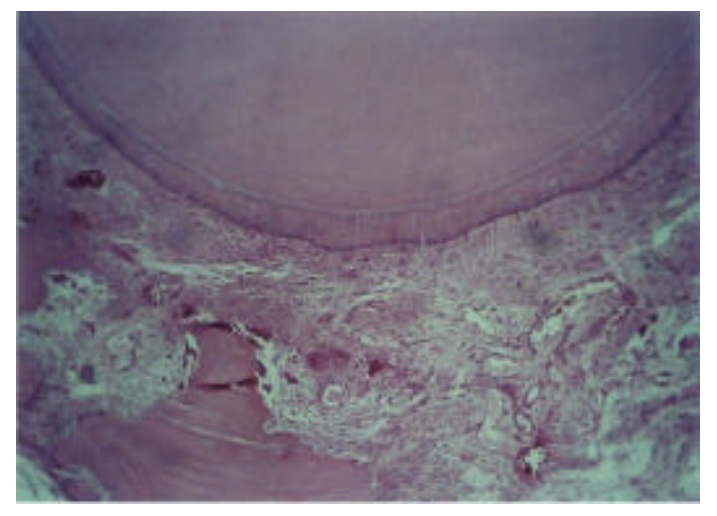

Figura 11 - Extrusão Cirúrgica, 7 dias, $1 / 3$ coronal. H.E. $10 \mathrm{X}$.

Ligamento periodontal íntegro junto à superfície radicular, ruptura na sua porção intermediária e presença de infiltrado inflamatório crônico.

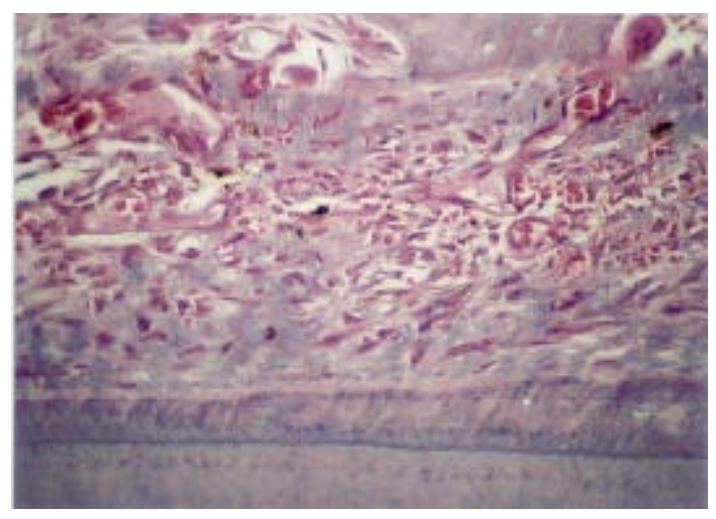

Figura 12 - Extrusão Cirúrgica, 7 dias, $1 / 3$ coronal. H.E. $40 \mathrm{X}$.

Ligamento periodontal íntegro junto à superfície radicular, ruptura na sua porção intermediária, intensa vascularização e presença de infiltrado inflamatório intenso.

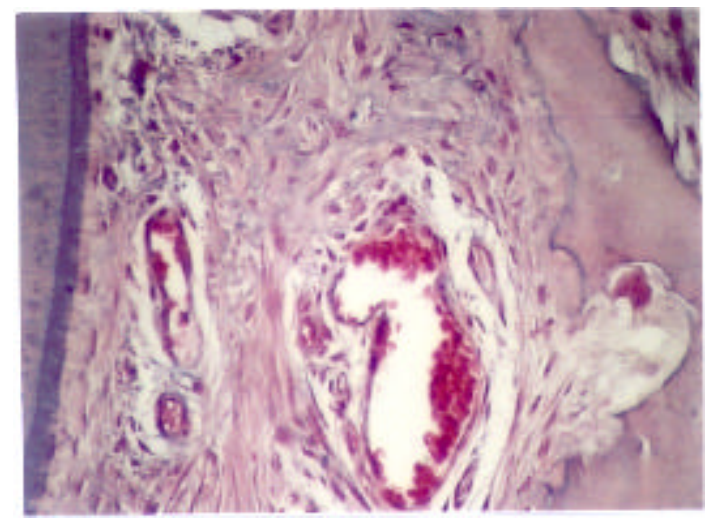

Figura 13 - Extrusão Cirúrgica, 7 dias, $1 / 3$ coronal. H.E. $40 \mathrm{X}$.

Aparência normal do ligamento periodontal denso, proliferação celular e vascular, e osteoclasia. 


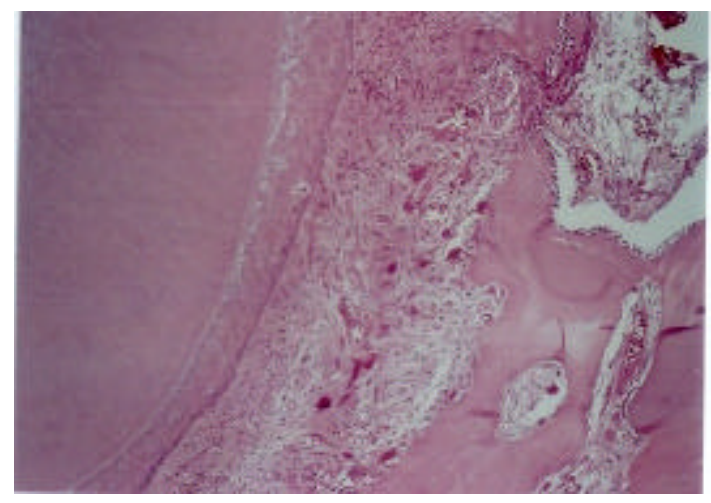

Figura 14 - Extrusão Cirúrgica, 7 dias, 1/3 médio. H.E. $10 \mathrm{X}$.

Ligamento periodontal íntegro junto à superfície radicular, ruptura na sua porção intermediária e presença de infiltrado inflamatório e atividade de reabsorção óssea.

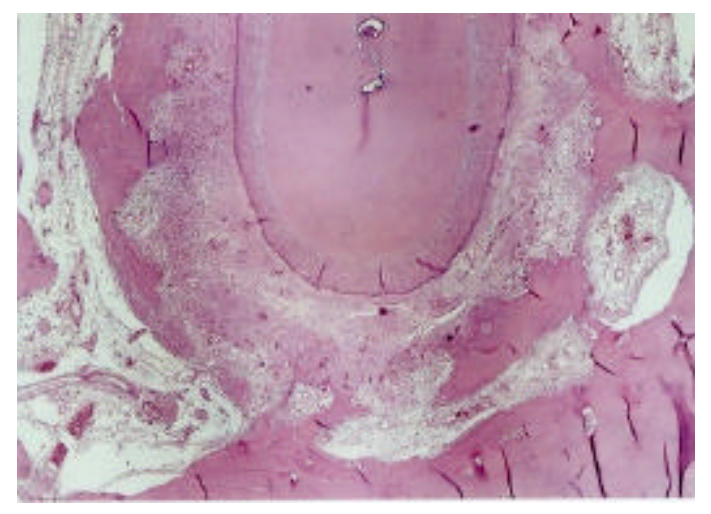

Figura 15 - Extrusão Cirúrgica, 7 dias, 1/3 apical. H.E. 4 X.

Irregularidade da largura do ligamento periodontal, sinais de ruptura na sua porção intermediária e também do seu restabelecimento.

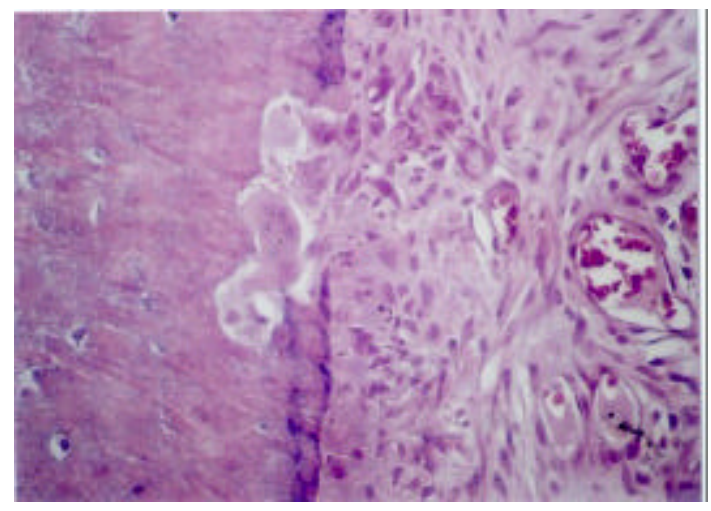

Figura 16 - Extrusão Cirúrgica, 7 dias, 1/3 apical. H.E. $40 \mathrm{X}$.

Solução de continuidade da camada cementária pela reabsorção de superfície ativa com a presença de células gigantes multinucleadas.

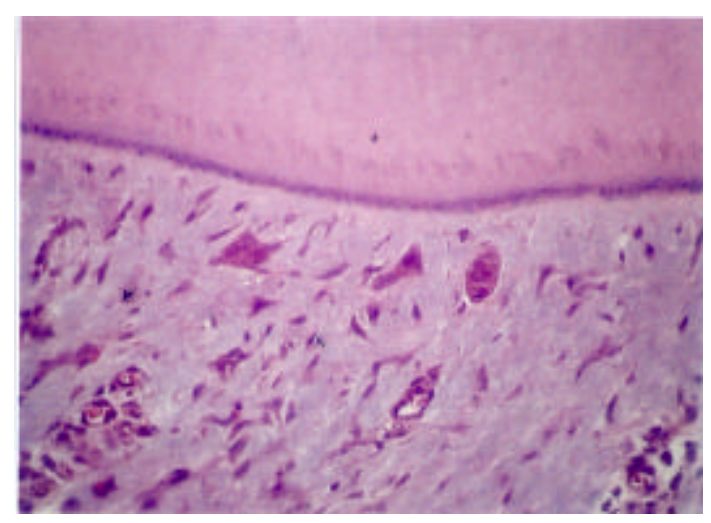

Figura 17 - Extrusão Cirúrgica, 7 dias, 1/3 apical. H.E. 40 X. Ligamento periodontal colagenoso e altamente celular, presença de restos epiteliais de Malassez. 

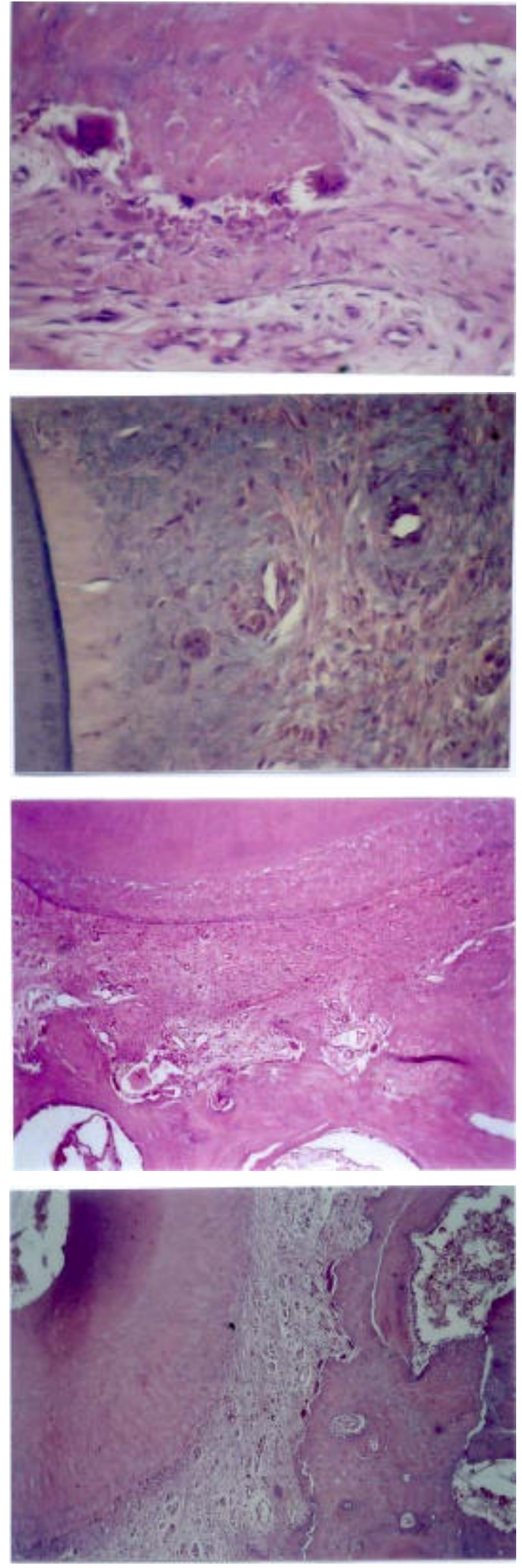

Figura 18 - Extrusão Cirúrgica, 7 dias, 1/3 apical. H.E. 40 X.

Superfície óssea com atividade de reabsorção e a presença de osteoclastos.

Figura 19 - Extrusão Ortodôntica, 7 dias, $1 / 3$ coronal. H.E. $40 \mathrm{X}$. Ligamento periodontal normalmente estruturado, discreta alteração na porção intermediária.

Figura 20 - Extrusão Ortodôntica, 7 dias, 1/3 médio. H.E. $10 \mathrm{X}$. Ligamento periodontal denso colagenoso e atividade de remodelamento ósseo.

Figura 21 - Extrusão Ortodôntica, 7 dias, 1/3 apical. H.E. $10 \mathrm{X}$.

Superfície óssea em remodelação com a presença de células gigantes multinucleadas. 

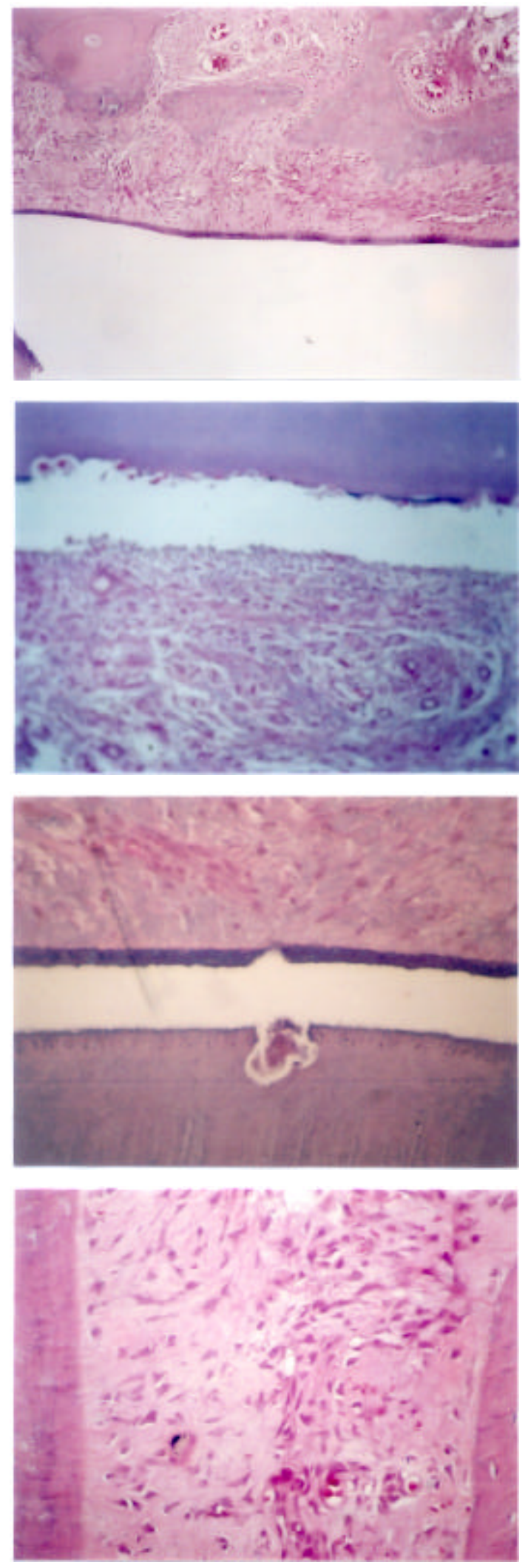

Figura 22 - Extrusão Cirúrgica, 14 dias, 1/3 coronal. H.E. $10 \mathrm{X}$.

Presença da ruptura do ligamento periodontal na sua porção intermediária e presença de infiltrado inflamatório crônico.

Figura 23 - Extrusão Cirúrgica, 14 dias, $1 / 3$ coronal. H.E. $40 \mathrm{X}$.

Reabsorção inflamatória ativa na superfície do cemento. Intenso infiltrado inflamatório.

Figura 24 - Extrusão Cirúrgica, 14 dias, $1 / 3$ coronal. H.E. $40 \mathrm{X}$.

Reabsorção de superfície ativa no cemento, célula gigante multinucleada na cavidade de reabsorção e ligamento denso colagenoso.

Figura 25 - Extrusão Cirúrgica, 14 dias, $1 / 3$ coronal. H.E. $40 \mathrm{X}$.

Proliferação de fibroblastos e de vasos sanguíneos na porção intermediária do ligamento periodontal. 


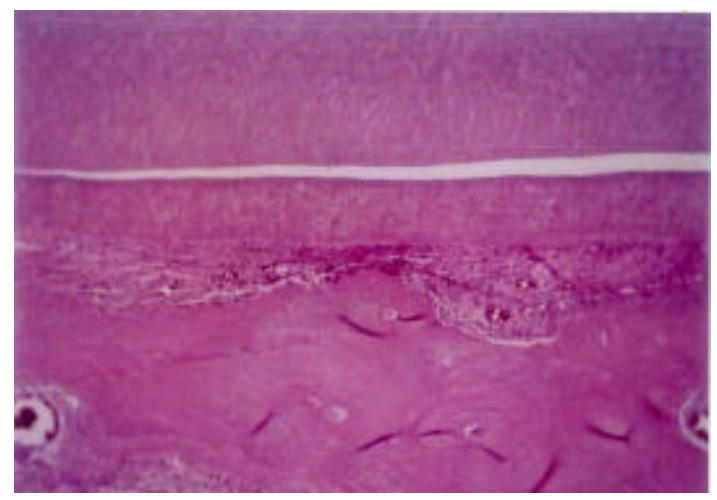

Figura 26 - Extrusão Cirúrgica, 14 dias, 1/3 médio. H.E. $10 \mathrm{X}$.

Largura irregular do ligamento periodontal, ilustrando uma área de proximidade maior entre $\mathrm{o}$ dente $\mathrm{e}$ osso alveolar.

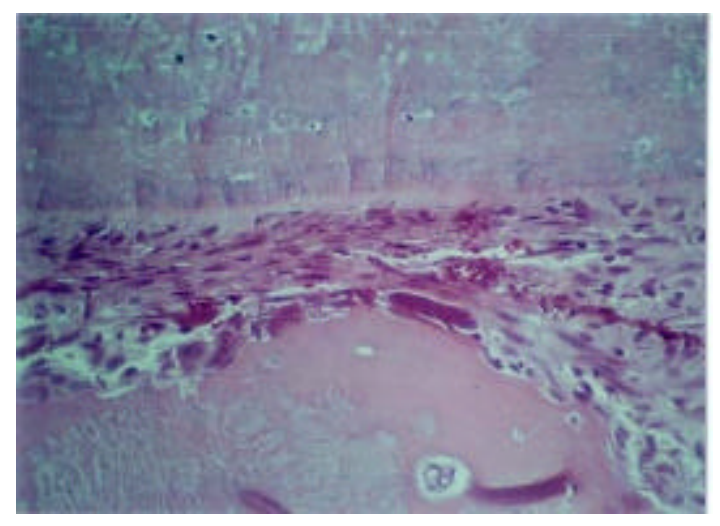

Figura 27 - Extrusão Cirúrgica, 14 dias, 1/3 médio. H.E. $40 \mathrm{X}$.

Atividade de reabsorção óssea no local de diminuição da largura do ligamento periodontal.

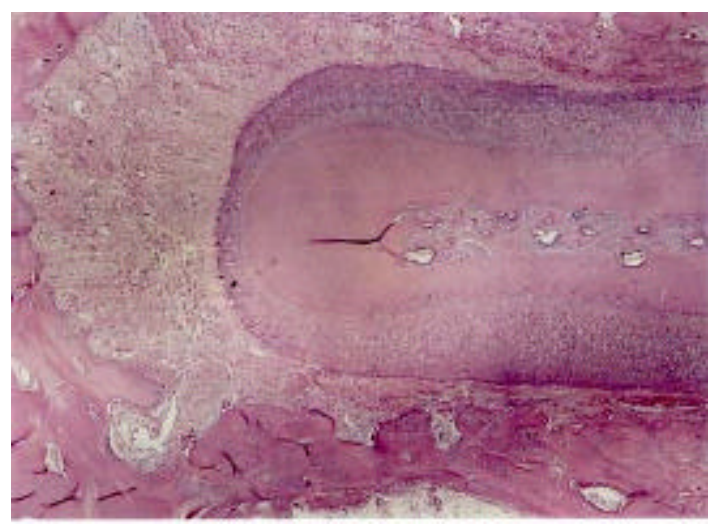

Figura 28 - Extrusão Cirúrgica, 14 dias, 1/3 apical. H.E. 4 X.

Aparência do ligamento periodontal restabelecido na sua maioria, a sua largura não é uniforme.

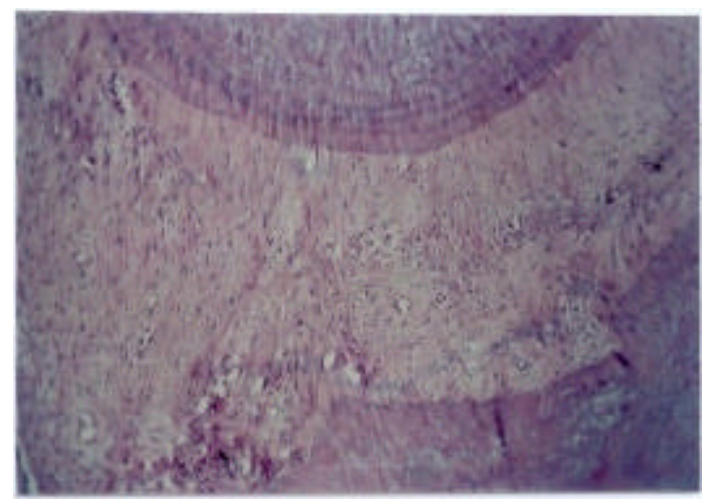

Figura 29 - Extrusão Cirúrgica, 14 dias, 1/3 apical. H.E. $10 \mathrm{X}$.

Ligamento periodontal restabelecido com proliferação de fibroblastos e presença de fibras de Sharpey. 

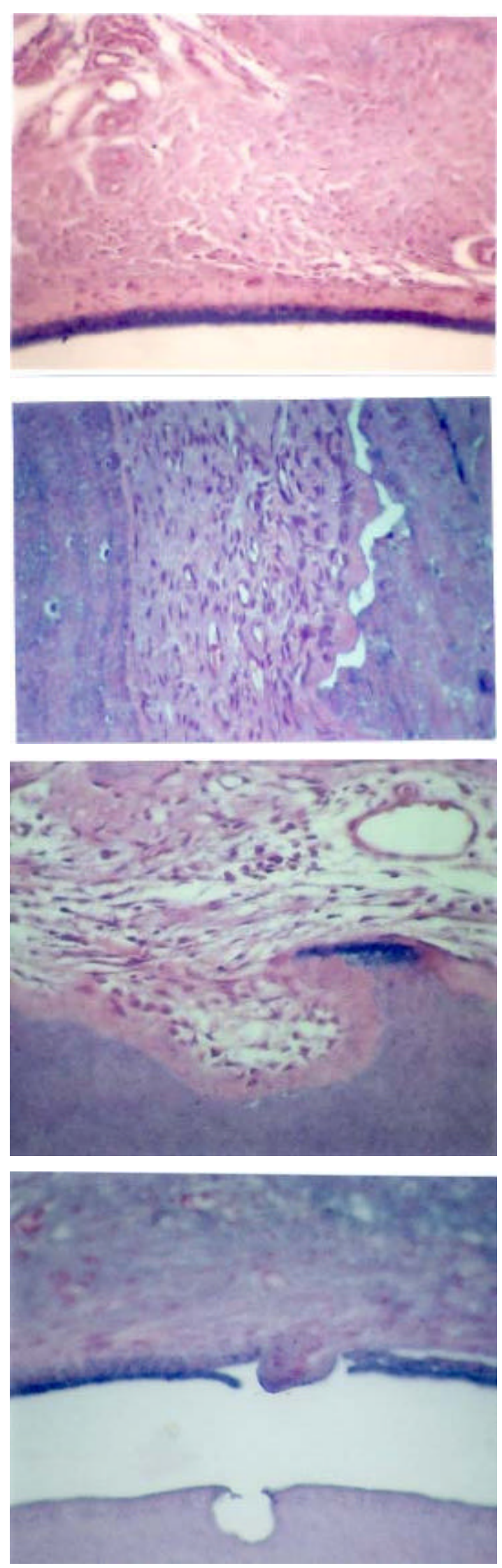

Figura 30 - Extrusão Ortodôntica, 14 dias, 1/3 coronal. H.E. $40 \mathrm{X}$.

Ligamento periodontal denso e colagenoso, observa-se ainda a presença de célula epitelial de Malassez junto àraiz.

Figura 31 - Extrusão Ortodôntica, 14 dias, 1/3 apical. H.E. 40 X.

Remodelação fisiológica do osso alveolar, ligamento periodontal denso fibroso e cemento íntegro.

Figura 32 - Extrusão Cirúrgica, 45 dias, $1 / 3$ coronal. H.E. 40 X.

Reparação da reabsorção inflamatória no cemento, presença de novo cemento e tecido conjuntivo pouco denso e infiltrado inflamatório crônico.

Figura 33 - Extrusão Cirúrgica, 45 dias, $1 / 3$ coronal. H.E. $40 \mathrm{X}$.

Reparação da reabsorção de superfície no cemento e tecido conjuntivo normal ao redor. 

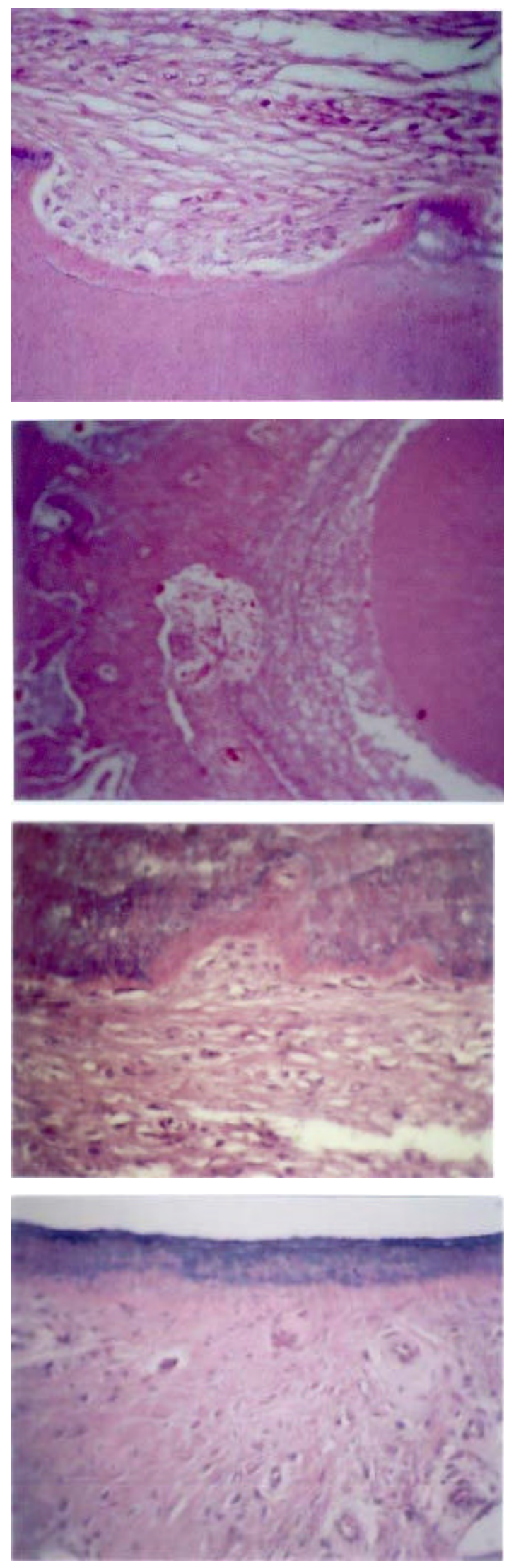

Figura 34 - Extrusão Cirúrgica, 45 dias, 1/3 médio. H.E. $40 \mathrm{X}$. Ligamento periodontal desorganizado na área da reparação de reabsorção de superfície na dentina.

Figura 35 - Extrusão Cirúrgica, 45 dias, 1/3 médio. H.E. $10 \mathrm{X}$.

Ancilose de cemento e osso alveolar e pequena área com reabsorção óssea no mesmo local.

Figura 36 - Extrusão Cirúrgica, 45 dias, 1/3 apical. H.E. $40 \mathrm{X}$.

Reparação da reabsorção de superfície no cemento, presença de novo cemento e tecido conjuntivo pouco denso e desorganizado.

Figura 37 - Extrusão Ortodôntica, 45 dias, $1 / 3$ coronal. H.E. $40 \mathrm{X}$.

Ligamento periodontal estruturado com densidade de colágeno e de fibroblastos, presença de restos epiteliais de Malassez. 

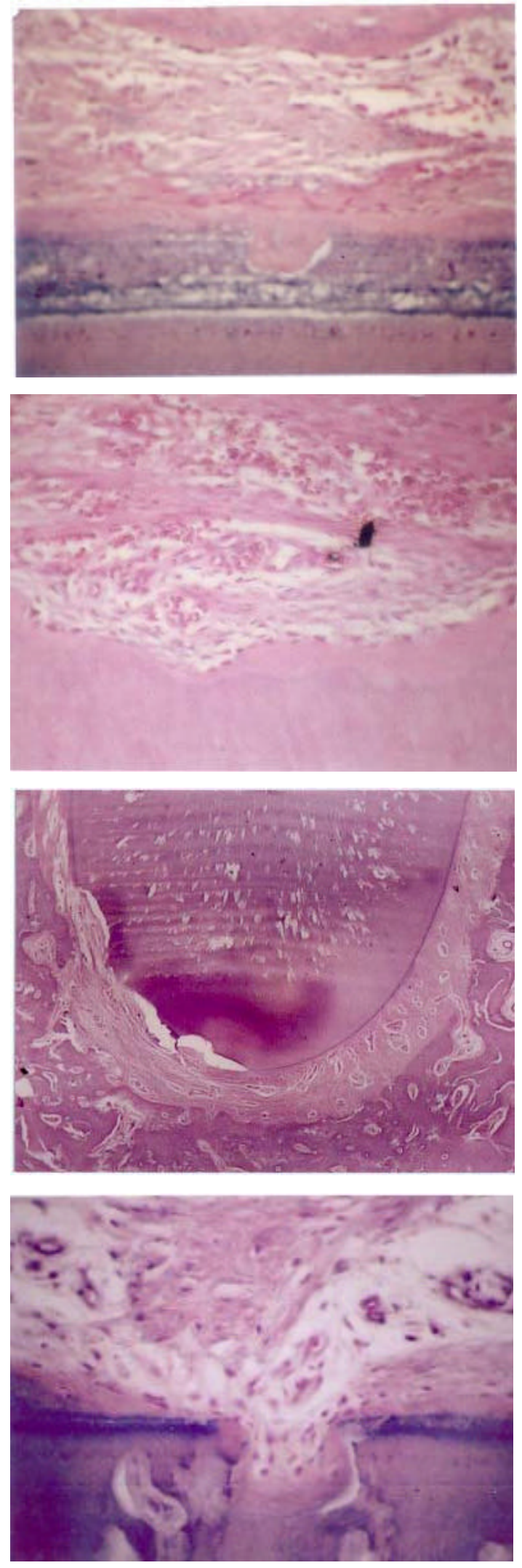

Figura 38 - Extrusão Ortodôntica, 45 dias, $1 / 3$ coronal. H.E. $40 \mathrm{X}$.

Reparação da reabsorção de superfície no cemento e ligamento pouco denso na região.

Figura 39 - Extrusão Ortodôntica, 45 dias, 1/3 médio. H.E. $40 \mathrm{X}$.

Reparação da reabsorção de superfície na dentina, formação de cemento novo e tecido conjuntivo pouco denso.

Figura 40 - Extrusão Cirúrgica, 90 dias, $1 / 3$ coronal. H.E. $10 \mathrm{X}$.

Extensa reparação da reabsorção de superfície na dentina com fibras colágenas paralelas e presença de ligamento periodontal restabelecido no outro lado.

Figura 41 - Extrusão Cirúrgica, 90 dias, 1/3 médio. H.E. $40 \mathrm{X}$.

Reparação da reabsorção de superfície no cemento e dentina por deposição de novo cemento, evidenciando tecido conjuntivo normal ao redor, porém ainda não funcional. 

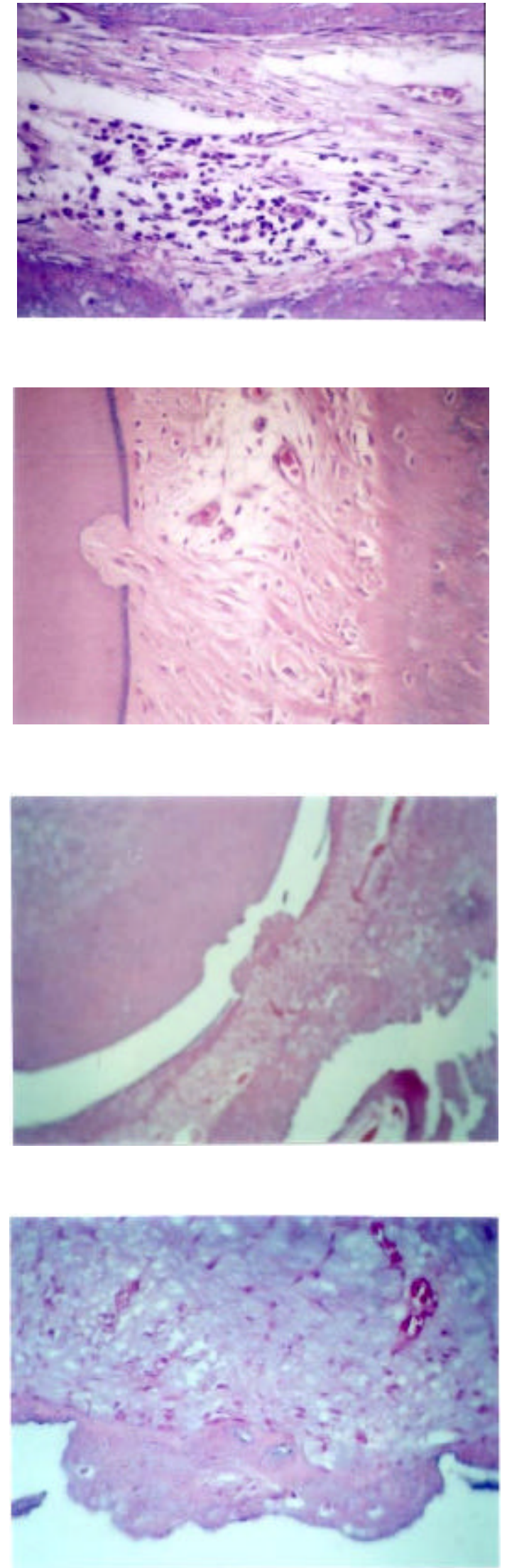

Figura 42 - Extrusão Cirúrgica, 90 dias, 1/3 apical. H.E. 40 X.

Reparação da reabsorção inflamatória na dentina, ligamento não funcional e presença de infiltrado inflamatório crônico.

Figura 43 - Extrusão Ortodôntica, 90 dias, $1 / 3$ coronal. H.E. 40 X.

Reparação da reabsorção de superfície no cemento, observa-se a inserção de fibras de Sharpey.

Figura 44 - Extrusão Ortodôntica, 90 dias, 1/3 médio. H.E. $10 \mathrm{X}$.

Reparação da reabsorção de superfície, presença de novo cemento e ligamento periodontal estruturado.

Figura 45 - Extrusão Ortodôntica, 90 dias, 1/3 médio. H.E. $40 \mathrm{X}$.

Reparação da reabsorção de superfície no cemento e tecido conjuntivo denso fibroso. 

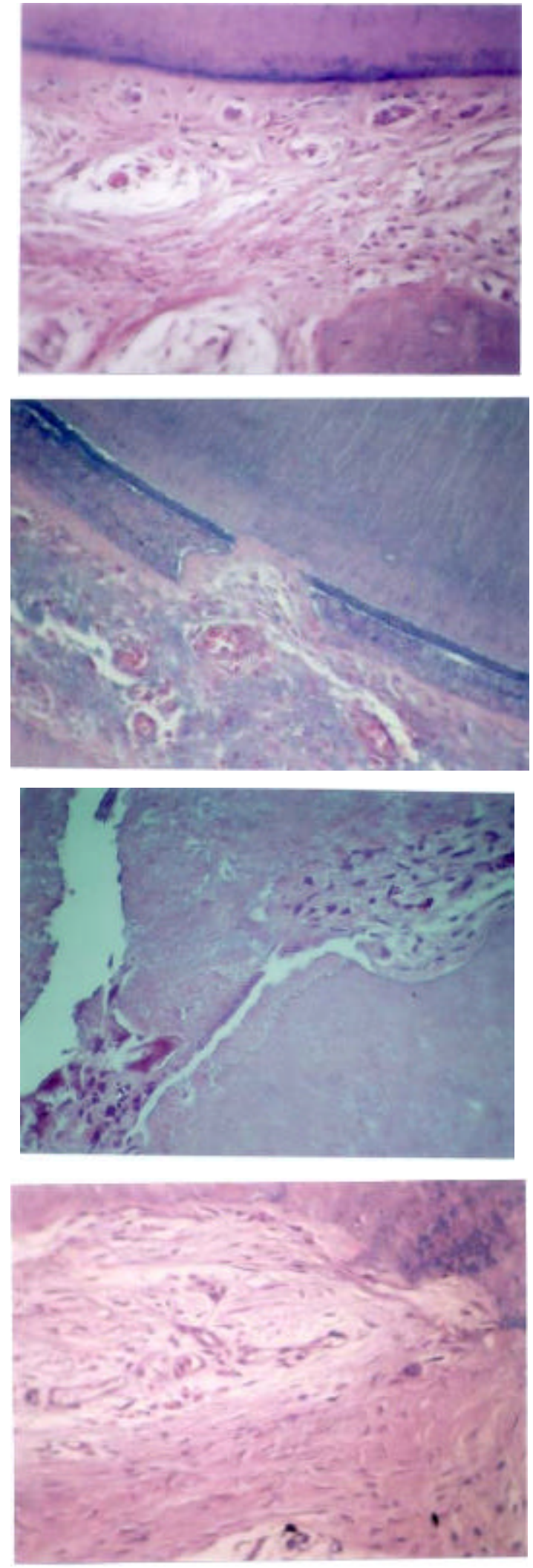

Figura 46 - Extrusão Ortodôntica, 90 dias, 1/3 apical. H.E. $40 \mathrm{X}$.

Ligamento periodontal, cemento e osso alveolar estruturados normalmente, presença de restos epiteliais de Malassez.

Figura 47 - Extrusão Cirúrgica, 120 dias, $1 / 3$ coronal. H.E. $10 \mathrm{X}$.

Reparação da reabsorção de superfície no cemento e dentina, observa-se a disposição paralela de fibras.

Figura 48 - Extrusão Cirúrgica, 120 dias, 1/3 médio. H.E. $40 \mathrm{X}$. Ancilose e reparação da reabsorção de superfície na dentina.

Figura 49 - Extrusão Cirúrgica, 120 dias, 1/3 apical. H.E. 40 X.

Reparação da reabsorção de superfície, presença de novo cemento e ligamento periodontal não funcional. 


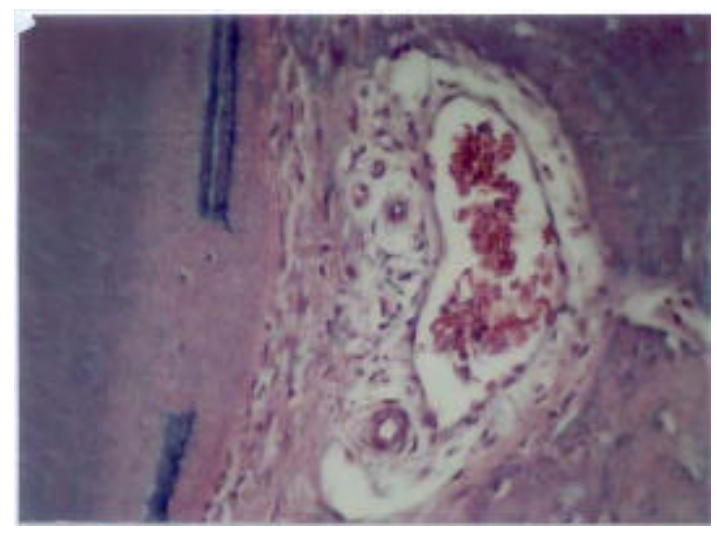

Figura 50 - Extrusão Ortodôntica, 120 dias, $1 / 3$ coronal. H.E. 40 X.

Reparação da reabsorção de superfície na dentina, ligamento não funcional.

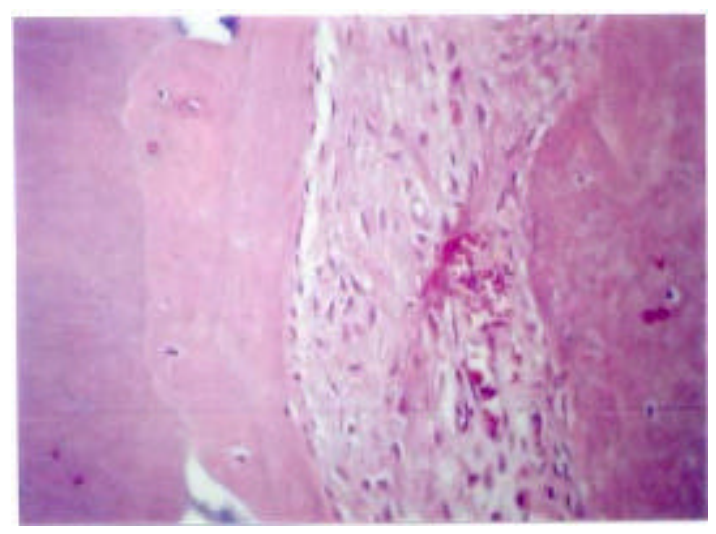

Figura 51 - Extrusão Ortodôntica, 120 dias, $1 / 3$ médio. H.E. 40 X.

Reparação da reabsorção de superfície na dentina e ligamento periodontal organizado. A reparação com característica de osteocemento.

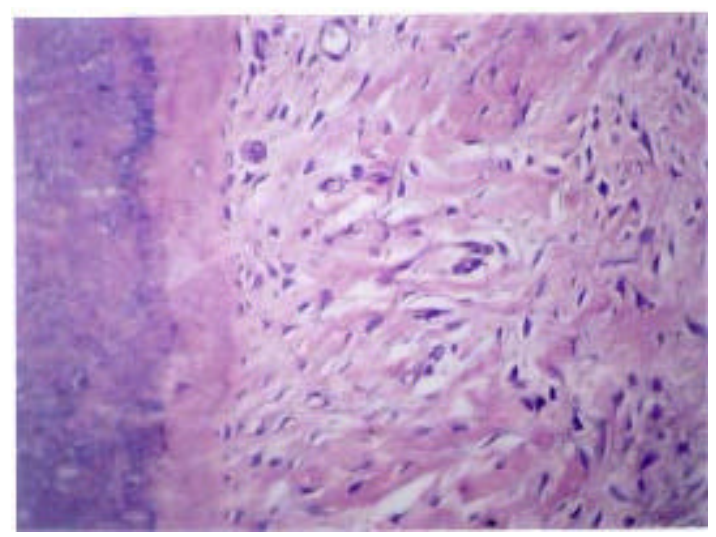

Figura 52 - Extrusão Ortodôntica, 120 dias, $1 / 3$ apical. H.E. 40 X.

Cemento e ligamento periodontal organizados, colágeno denso e restos epiteliais de Malassez.

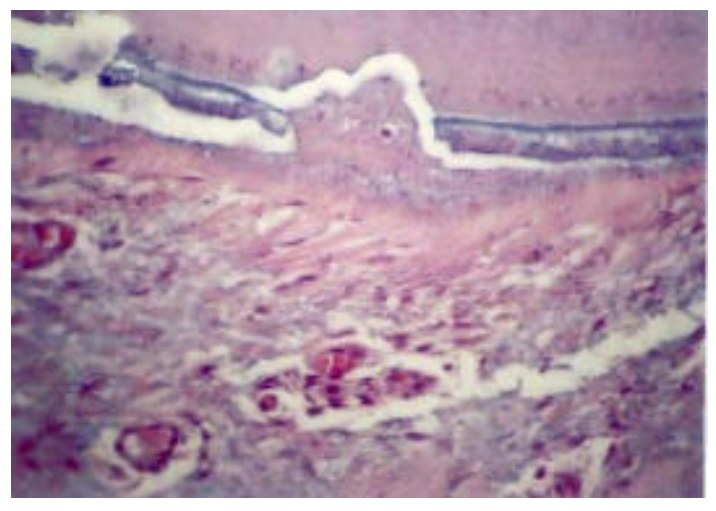

Figura 53 - Extrusão Cirúrgica, 180 dias, $1 / 3$ coronal. H.E. $40 \mathrm{X}$.

Reparação da reabsorção de superfície no cemento e tecido conjuntivo denso fibroso. A reparação com característica de osteocemento. 

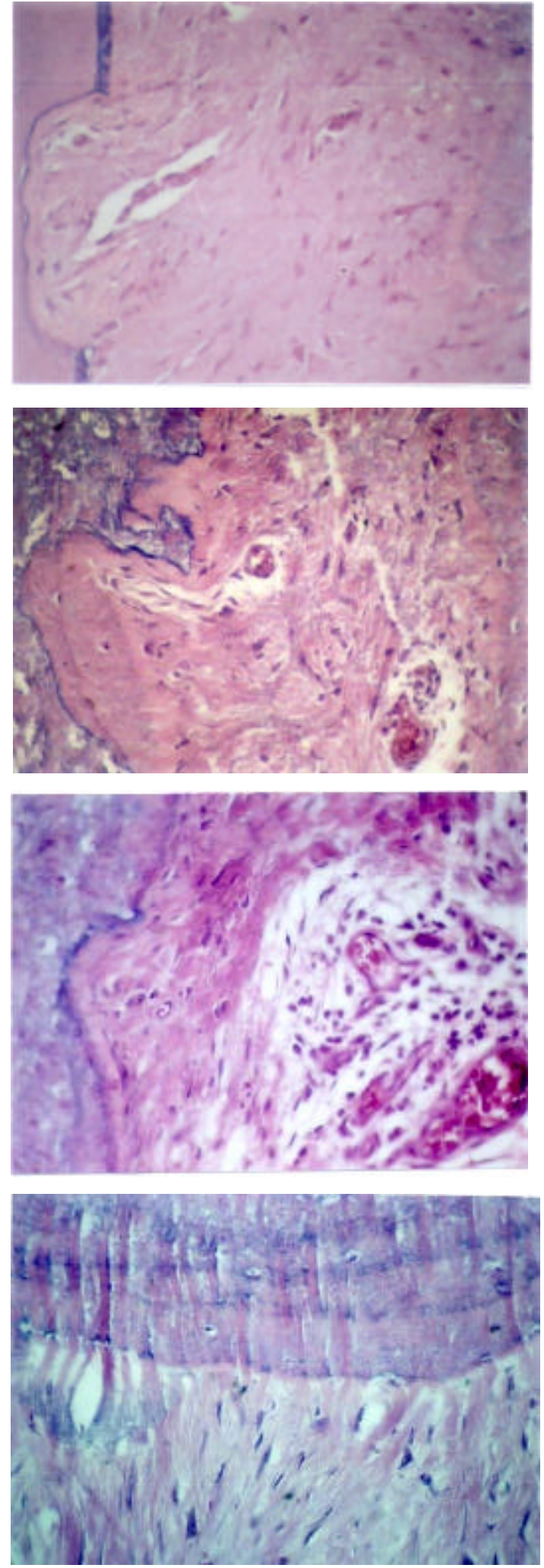

Figura 54 - Extrusão Cirúrgica, 180 dias, 1/3 médio. H.E. $40 \mathrm{X}$.

Reparação da reabsorção de superfície na dentina, ligamento periodontal denso funcional.

Figura 55 - Extrusão Cirúrgica, 180 dias, 1/3 apical. H.E. 40 X.

Reparação da reabsorção de superfície na dentina, observa-se a inserção de fibras de Sharpey no novo cemento.

Figura 56 - Extrusão Cirúrgica, 180 dias, 1/3 apical. H.E. 40 X.

Reparação da reabsorção inflamatória, tecido conjuntivo fibroso junto ao cemento neoformado e presença do infiltrado inflamatório crônico.

Figura 57 - Extrusão Cirúrgica, 180 dias, 1/3 apical. H.E. $40 \mathrm{X}$.

Ligamento periodontal estruturado com fibras de Sharpey. 


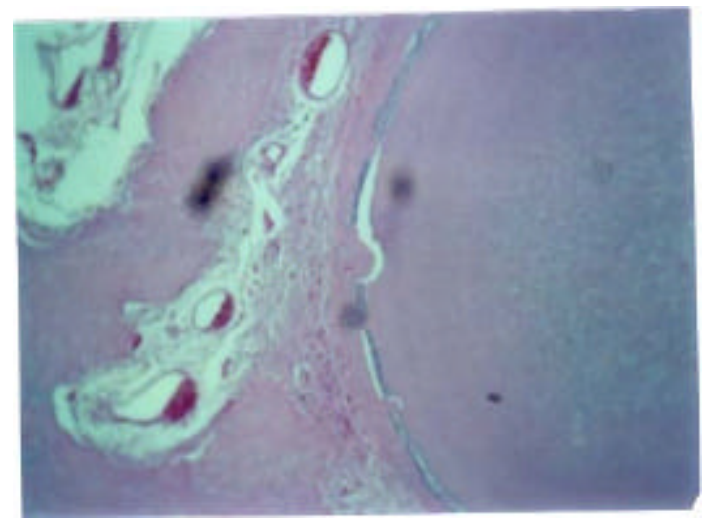

Figura 58 - Extrusão Ortodôntica, 180 dias, $1 / 3$ coronal. H.E. $10 X$.

Reparação da reabsorção de superfície no cemento e ligamento periodontal organizado.

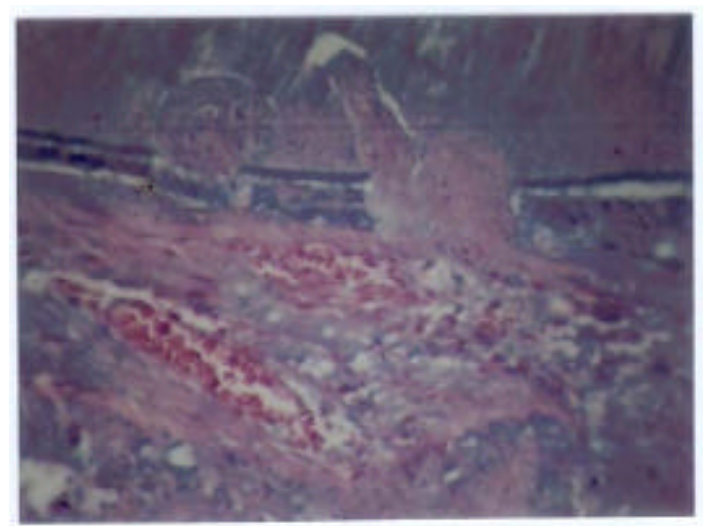

Figura 59 - Extrusão Ortodôntica, 180 dias, 1/3 médio. H.E. 40 X.

Reparação da reabsorção de superfície no cemento e dentina, ligamento periodontal denso funcional.

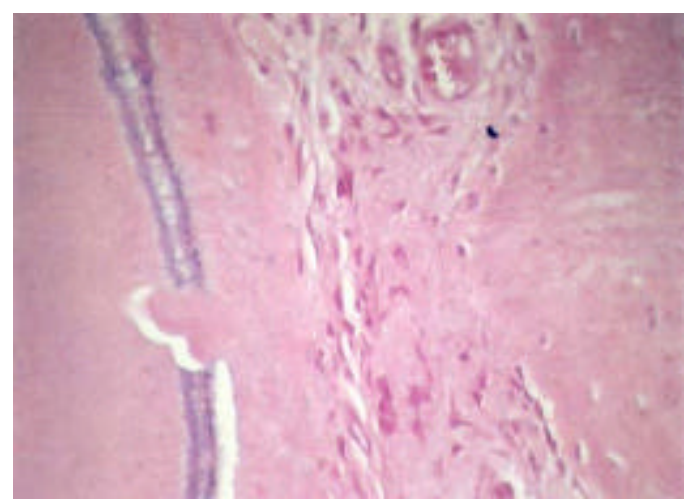

Figura 60 - Extrusão Ortodôntica, 180 dias, $1 / 3$ apical. H.E. 40 X.

Reparação da reabsorção de superfície na dentina, observa-se um ligamento organizado.

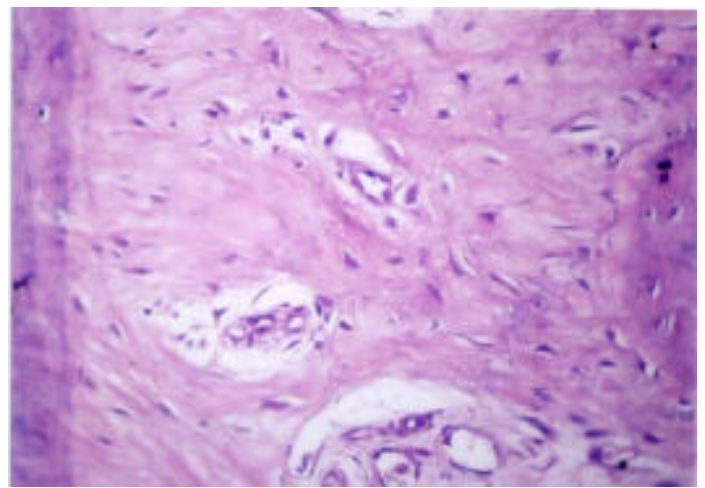

Figura 61 - Extrusão Ortodôntica, 180 dias, $1 / 3$ apical. H.E. 40 X.

Ligamento periodontal estruturado com fibras de Sharpey. 
6. DISCUSSÃO 


\section{6 - DISCUSSÃO}

O comportamento clínico do método de extrusão cirúrgica tem sido considerado conservador baseado nas avaliações clínico-radiográficas $\left(\right.$ KAHNBERG $^{43}, 1985$; KAHNBERG ${ }^{45}, 1996 ;$ KAHNBERG, WARFVINGE \& BIGERSSON ${ }^{46}, 1982$; KIM et $\mathrm{al}^{48}, 2001$; KIM, TRAMONTINA \& PASSANEZ4 ${ }^{47}$, 2002; MAGINI et al. ${ }^{57}, 1998$; TEGSJÖ, VALERIUS \& OLGART ${ }^{80}, 1978$ ). Todavia, não havendo estudos experimentais para confirmar esta hipótese, a sua compreensão foi baseada no comportamento biológico da cicatrização após o reimplante dentário imediato (ANDERSON, SHARAV \& MASSLER ${ }^{1}, 1968$; ANDREASEN $^{12}, 1981$; ANDREASEN ${ }^{15}, 1987$; ANDREASEN \& HJORTINGHANSEN $^{17}, 1966$; HAMMER $^{38}, 1955$; LOE \& WAERHAUG ${ }^{56}, 1961$; NASJLETI et $\left.\mathrm{al}^{60}, 1975\right)$.

Da mesma maneira, os resultados clínicos da extrusão ortodôntica são considerados mais fisiológicos quando da aplicação de força leve. É pressuposto que na extrusão lenta ou seja, aplicação da força leve considerada ótima não promove alterações patológicas durante a movimentação dentária. Esta força pode variar entre 25 e 60 gramas (PROFFIT \& FIELDS Jr. ${ }^{69}, 2002$; STROSTER $\left.^{78}, 1990\right)$, porém, muitas vezes o controle desta pode fugir do alcance clínico e assim superar os níveis fisiológicos. Por esta razão, neste estudo a extrusão preconizada foi rápida, determinando o espaço de $3 \mathrm{~mm}$ para tração, além disso foi utilizada força maior que a fisiológica, considerando assim, uma situação clínica cotidiana. 
Os resultados da cicatrização do periodonto e das estruturas anexas mostraram comportamentos fisiológicos e patológicos. No ligamento periodontal foram observadas mudanças fisiológicas de adaptação à demanda para o grupo controle e restabelecimento das fibras colágenas rompidas por meio da proliferação celular e fibrilar para o grupo experimental. Nas superfícies ósseas também ocorreram adaptação funcional à demanda promovendo reabsorção e reparação, enquanto que nas superfícies radiculares ocorreram reabsorções tanto nos dentes que foram submetidos à extrusão cirúrgica como à extrusão ortodôntica. Apesar disso todas as lacunas de reabsorção, seja no cemento ou na dentina, foram reparadas com deposição de novo cemento e novo ligamento periodontal. Independentemente da variação nos resultados entre os grupos experimental e controle, os resultados finais deste estudo mostraram reparação completa e funcional do periodonto em ambos os grupos, confirmando assim o comportamento clínico destes procedimentos.

Foi encontrada a presença constante de ligamento periodontal denso fibrilar e celular adjacente àsuperfí cie da raiz e osso alveolar em todos os níveis no grupo de 7 dias após extrusão cirúrgica. Apesar dos sinais evidentes da ruptura das fibras colágenas, o ligamento periodontal mostrou atividade proliferativa intensa. Embora espessado e alargado pela extrusão coronal da raiz, aumentando a largura entre a raiz e osso alveolar, o ligamento periodontal apresentou feixes de fibras colágenas e fibroblastos normais em grande quantidade. As fibras colágenas mostraram capacidade de novamente se unir em todos os terços avaliados: coronal, médio e apical. Neste último, em algumas áreas mostrourse restabelecimento dos feixes de fibras entre dente e osso 
alveolar, concordando assim com os achados de HAMMER ${ }^{38}$ (1955). Segundo o autor, o papel do ligamento periodontal na reimplantação dentária é similar ao papel do periósteo no transplante de osso e a sobrevivência de um dente reimplantado é proporcional à quantidade de ligamento periodontal preservado. Sobre a cicatrização do ligamento periodontal após reimplante dentário imediato, o autor relatou que em 4 dias ambas as estruturas, osso e dente preservaram ligamento periodontal, conectando-os por uma ciatrização recente.

Neste experimento, no momento da extração da raiz, o ligamento periodontal se rompeu na sua porção intermediária e assim foi dividido em duas partes, uma ligada ao dente e outra ligada à parede óssea alveolar. O ligamento periodontal adjacente à raiz foi mantido intacto e sem manuseio até a reposição do dente no seu alvéolo. O manuseio sobre o ligamento periodontal remanescente no ato cirúrgico poderia afetar a vitalidade do mesmo, independentemente do tempo de permanência fora do alvéolo, concordando assim com a opinião de VAN-HASSEL, OSWALD \& HARRINGTON ${ }^{82}$ (1980).

No trans-operatório da extrusão cirúrgica, a permanência da raiz fora do alvéolo foi breve, poucos segundos. ANDREASEN ${ }^{6}$ (1980), $\operatorname{ANDREASEN}^{10}$ (1981), ANDREASEN ${ }^{12}$ (1981) consideraram a reimplantação imediata do dente avulsionado no alvéolo como sendo um dos fatores mais importantes que contribui para a cicatrização do ligamento periodontal. Os resultados iniciais da cicatrização do ligamento periodontal do grupo experimental do presente estudo confirmam a necessidade da reposição imediata do dente no seu alvéolo, concordando com os achados dos estudos supra citados. 
Os resultados do período de 7 dias de extrusão cirúrgica mostraram claramente a reparação das fibras colágenas rompidas. Apesar desta reparação ter sido tênue e ainda na presença dos sinais de ruptura do ligamento periodontal e no local permeado por infiltrado inflamatório crônico difuso, o ligamento periodontal mostrou reorganização.

É importante ressaltar a diferença entre um dente reimplantado e outro extruído cirúrgicamente. No primeiro, o dente se reposiciona no alvéolo, enquanto que no outro, o mesmo se desloca coronalmente adaptando-se em nova posição, aumentando significativamente a largura do ligamento periodontal. Por isso, observou-se atraso na cicatrização no grupo da extrusão cirúrgica em comparação com a que ocorrera nos estudos de reimplante dentário imediato (ANDREASEN $^{6}, 1980$; CASTELLI et al. ${ }^{28}, 1980$; HAMMARSTRÖM et al ${ }^{37}, 1986$; HAMMER $^{38}, 1955$; NASJLETI, CASTELLI \& CAFFESSE $\left.{ }^{62}, 1982\right)$.

Conforme os estudos experimentais de ANDREASEN ${ }^{6}$ (1980) e ANDREASEN $^{10}$ (1981), os eventos de reabsorção radicular têm ocorrência inicialmente 2 semanas após o reimplante dentário imediato. No entanto, neste estudo foi observada atividade de reabsorção radicular precoce, no período de 7 dias, pois pequenas cavidades isoladas no cemento e localizadas no terço apical representaram reabsorção de superfície.

Ainda neste período, diferentemente da superfície radicular, o osso alveolar demonstrou grande metabolismo, adaptando-se às condições do trauma físico que ocorrera na avulsão dentária. As reabsorções na sua superfície foram evidentes e células gigantes multinucleadas apareceram associadas às lacunas de reabsorção. Ao mesmo tempo, foram vistas células de revestimento 
linearmente dispostas sobre a parede óssea alveolar, demonstrando assim, a atividade proliferativa. $\mathrm{O}$ processo de reparação óssea ocorreu em todos os níveis observados.

Os requisitos funcionais do ligamento periodontal são dependentes da presença das fibras de Sharpey ligando cemento e osso alveolar, e este fenômeno biológico foi observado no período de 14 dias da extrusão cirúrgica. No entanto, somente no período de 45 dias de extrusão cirúrgica, a maior parte em torno da raiz que não sofreu nenhum tipo de reabsorção mostrou ligamento periodontal denso e funcional, ocorrendo o fenômeno "restitutio ad integrum".

Essa observação funcional do ligamento periodontal no período de 45 dias corrobora os achados sobre a diminuição da mobilidade dentária após a extrusão cirúrgica em pacientes, mostrando assim a indicação segura para restauração da função oclusal do dente extruído cirurgicamente após 4 a 6 semanas (KAHNBERG ${ }^{43}, 1985$; KAHNBERG ${ }^{45}, 1996$; KAHNBERG, WARFVINGE \& BIGERSSON ${ }^{46}, 1982 ; \mathrm{KIM}$ et $\mathrm{al}^{48}, 2001$; KIM, TRAMONTINA \& PASSANEZ ${ }^{47}$, 2002 ; TEGSJÖ, VALERIUS \& OLGART $\left.{ }^{80}, 1978\right)$.

O grau ou a extensão da reabsorção radicular externa em dentes reimplantados foi relacionado ao estágio do desenvolvimento do dente, período de tempo extra-alveolar, meio de estocagem e reimplantação imediata. Segundo ANDREASEN et al. ${ }^{16}$ (1995), o destino dos dentes reimplantados podem envolver diferentes cicatrizações como: cicatrização normal do periodonto (24\%), reabsorção de superfície $(4,5 \%)$, reabsorção inflamatória (30\%) e reabsorção por substituição (61\%). 
Apesar da semelhança nos procedimentos clínicos entre o reimplante dentário imediato e extrusão cirúrgica dentária, resultados diferentes foram observados neste estudo. As ocorrências histológicas mostraram concentração maior na reabsorção de superfície e menor na reabsorção por substituição.

A manutenção da integridade do ligamento periodontal foi fundamental no restabelecimento fisiológico do mesmo em nova posição. A maioria absoluta do periodonto normal foi mantido e observado em todos os períodos de cicatrização. A reabsorção ativa foi observada em poucas amostras. As reabsorções de superfície ativa e reabsorção inflamatória ativa foram discretas nos períodos iniciais de 7 e 14 dias. Porém, a atividade de reabsorção não visualizada nestes períodos não significou a sua ausência, o que pôde ser confirmado pela observação da reparação das reabsorções radiculares em maior escala nos períodos tardios. A partir de 45 dias de observação, a presença de diferentes graus da reparação das reabsorções de superfície, inflamatória e por substituição foi notável e nos períodos mais avançados mostrou estabilidade funcional destas reparações nas lacunas de reabsorção.

A grande preocupação no reimplante dentário é sem dúvida a ocorrência da ancilose no período da cicatrização (ANDERSSON et $\mathrm{al}^{4}, 1985$; ANDREASEN $^{10}, 1981 ; \quad$ ANDREASEN $^{12}, 1981 ; \quad$ ANDREASEN \& KRISTERSON ${ }^{19}, 1981$; ANDREASEN et al. $^{16}, 1995$; BLOMLÖF et $\mathrm{al}^{25}, 1983$; KRISTERSON \& ANDREASEN ${ }^{51}, 1983$; PETTIETTE et al. ${ }^{68}$,1997). Entretanto, na extrusão cirúrgica a ancilose foi um fenômeno discreto, observado nos períodos isolados de 45 e 120 dias (Gráfico 5 e 9). A ocorrência inicial da 
ancilose no período de 45 dias corrobora o estudo de $\operatorname{ANDREASEN~}^{10}(1981)$, segundo o qual, o período crítico para a formação da ancilose pode variar de 2 a 8 semanas.

Os resultados deste estudo mostram número significativamente maior de ancilose no grupo de 45 dias da extrusão cirúrgica entre os períodos avaliados. Apesar da presença de ancilose, o maior envolvimento entre os tipos de reabsorção foi a de superfície e por conseqüência ocorrendo a sua reparação. A resposta a esta diferença em relação ao reimplante dentário pode estar relacionada ao tempo de permanência fora do alvéolo e por conseqüência à manutenção da vitalidade do ligamento periodontal e também pela ausência da esplintagem do dente que sofreu a extrusão cirúrgica.

Os estudos clínicos de extrusão cirúrgica têm demonstrado que para se alcançar a estabilidade no alvéolo não é preciso aplicar a esplintagem dentária (KAHNBERG ${ }^{43}, 1985$; KAHNBERG ${ }^{45}, 1996$; KAHNBERG, WARFVINGE \& BIGERSSON ${ }^{46}, 1982 ; \mathrm{KIM}$ et $\mathrm{al}^{48}, 2001$; KIM, TRAMONTINA \& PASSANEZ ${ }^{47}$, 2002 ; TEGSJÖ, VALERIUS \& OLGART $\left.{ }^{80}, 1978\right)$.

Seguindo este raciocínio, aos dentes que foram submetidos à extrusão cirúrgica não foi aplicado nenhum tipo de esplintagem, mas somente um apoio incisal no dente extruído para que não houvesse o risco de exfoliação imediata. Neste momento o dente estava totalmente suspenso e a mobilidade era total em função da ruptura do ligamento periodontal e do aumento da sua largura pela posição coronal da raiz. A estabilização inicial da raiz dentro do alvéolo se fez pela formação do coágulo intra-alveolar, impedindo assim a intrusão da raiz, 
sendo que a extrusão desta foi contida pelo apoio incisal, mantendo assim a mobilidade funcional da raiz no alvéolo.

Apesar de se ter seccionado a coroa, ficando apenas a raiz e fora de oclusão, algum estímulo funcional pelo contato com os alimentos e tecidos moles bucais, principalmente lábios e língua ocorreu no período de cicatrização. O exercício da função ou estímulo do dente no alvéolo parece ter papel importante na prevenção do processo de ancilose após a nova posição dentária (ANDREASEN ${ }^{5}, 1975$; KRISTERSON \& ANDREASEN ${ }^{51}$, 1983). Como o período crítico para a formação da ancilose pode variar de 2 a 8 semanas $\left(\right.$ ANDREASEN $\left.^{10}, 1981\right)$ propõe-se aplicação do conceito da estimulação imediata após a extrusão cirúrgica para a prevenção desta. Os resultados deste estudo concordam a proposição anterior.

Em conjunção àmanutenção da vitalidade do ligamento periodontal, o estímulo funcional pode ter contribuído para o comportamento da atividade de reabsorção por substituição nos dentes que se submeteram à extrusão cirúrgica. Assim, os resultados deste experimento corroboram os estudos de reimplante dentário com estímulo mastigatório funcional (ANDERSSON et al. ${ }^{4}, 1985$; ANDREASEN ${ }^{5}, 1975$; ANDREASEN \& SKOUGAARD ${ }^{21}, 1972$; KRISTERSEN \& ANDREASEN ${ }^{51}, 1983$; NASJLETI, CASTELLI, CAFFESSE $\left.{ }^{62}, 1982\right)$.'

A permanência breve da raiz fora do alvéolo até sua reposição e a preservação da mobilidade funcional da raiz mostraram a importância nos resultados da cicatrização do periodonto no grupo experimental. Segundo ANDREASEN ${ }^{5}, 1975$; ANDREASEN ${ }^{11}, 1981$; KRISTERSEN \& ANDREASEN 
${ }^{51}, 1983$, a extensão da reabsorção por substituição ou ancilose é proporcional ao tempo de permanência do dente fora do alvéolo.

Comprometimento menor e variação da ancilose observada nos períodos de 45 e 120 dias e a sua ausência nos outros períodos pode significar a reparação da mesma por motivo funcional do dente. Isto foi visualizado nas amostras em que houve reabsorção óssea no local da ancilose, dando a impressão da reparação do espaço para o ligamento periodontal.

Foi demonstrado que a ancilose pode ser transitória em locais de agressão moderada nos dentes submetidos ao reimplante experimental em animais. Quando há exposição radicular pelo dano mecânico, a ancilose que se estabelece rapidamente poderá ser eliminada pela proliferação das células do ligamento periodontal adjacente à ferida (ANDREASEN \& $\operatorname{KRISTERSON}^{20}, 1981$; ANDREASEN \& SKOUGAARD ${ }^{21}, 1972$; BLOMLÖF \& LINDSKOG $\left.{ }^{26}, 1994\right)$.

O processo de reabsorção da superfície radicular parece ser similar ao do osso alveolar. Para que isso ocorra, é preciso que se exponha a camada inorgânica para deflagrar o início da reabsorção (TRONSTAD $\left.{ }^{81}, 1988\right)$. Em condições fisiológicas e normais, a superfície externa da raiz está coberta por uma camada orgânica ou cementóide, encontrando-se inseridas fibras de Sharpey e havendo ainda uma camada de cementoblastos ou células de revestimento linear, em adição à presença dos restos epiteliais de Mal assez do ligamento periodontal.

A integridade das fibras de Sharpey no cemento parece ser de suma importância e fundamental para proteção da raiz frente à reabsorção. A representação tridimensional da inserção destas fibras pode reafirmar o conceito 
da barreira mecânica. As fibras junto à superfície do cemento são tão intimamente ligadas e fechadas, que em circunstâncias normais elas agiriam junto com os cementoblastos como um obstáculo a qualquer processo exploratório de osteoclastos.

Em todas as amostras dos grupos experimental e controle onde a continuidade da camada cementária e a inserção de fibras de Sharpey foram mantidas não se observou atividade de reabsorção. Todas as reabsorções observadas nas amostras dos diferentes períodos dos grupos controle e experimental foram semelhantes, no local da reabsorção a solução de continuidade da camada de cemento foi evidente. Portanto, a importância da persistência de fragmentos do ligamento periodontal inserido no cemento radicular e a camada orgânica deste para servir como barreira mecânicabiológica àreabsorção radicular externa, parece ser indiscutível.

Todavia, as primeiras evidências de ligamento periodontal e cemento normais e as ausências de solução de continuidade no cemento do perímetro radicular e de reabsorção radicular observadas nos períodos de 7 e 14 dias do grupo controle não são conclusivas. Esta condição de normalidade quase absoluta não se repetiu nos períodos seguintes neste grupo, pois o que se observou nos períodos subsequentes foi a reparação de reabsorções (Gráficos 1a12).

No período de 7 dias, em dentes que sofreram extrusão cirúrgica, o ligamento periodontal foi rompido, havendo separação nítida das fibras colágenas no segmento intemediário, porém, ainda assim o ligamento periodontal estava densamente inserido à superfície radicular (Figuras 9 a 16 ). A solução de 
continuidade no cemento do perímetro radicular só foi observada no terço apical e neste local haviam pequenas e discretas cavidades de reabsorção de superfície no cemento. Por esta análise poderia se supor que haveria atividade de reabsorção discreta e localizada. No entanto, isto não se confirmou e reabsorções de superfície e inflamatória ativas estiveram em maior número no período seguinte de 14 dias (Gráfico 3). As mudanças de comportamento biológico após a agressão física pode ter levado à exposição bioquímica atraindo as células gigantes multinucleadas ao local, para o início da reabsorção radicular. Portanto, a não observação da ruptura da camada cementária no período de 7 dias, não significou ausência completa da atividade de reabsorção. Esta atividade seria confirmada posteriormente na avaliação dos períodos seguintes, tanto no grupo controle como no experimental, quando as cavidades de reabsorção de superfície no cemento elou na dentina estavam reparadas, significando, assim, atividade de reabsorção em períodos anteriores que não foram observadas.

Apesar da extrusão ortodôntica ser considerada mais conservadora do que a cirúrgica, por não causar ruptura das fibras do ligamento periodontal, a partir de 45 dias ocorreram também alterações na superfície radicular. A reparação das reabsorções de superfície, que variou de discreta a moderada, foi constatada (Gráfico 6,8,10,12).

É preciso salientar que os períodos de observação deste grupo não foram fieis aos períodos de cicatrização. Isto porque para avaliação conjunta dos dentes controle e experimental foi adotada como referência comum o término das extrusões dentárias. A extrusão ortodôntica foi iniciada primeiro e levou em média 3 a 4 semanas para o término, significando assim que os resultados do grupo 
controle são mais tardios do que o grupo experimental. Talvez por isso os fenômenos histológicos precoces não tenham sido observados mesmo nos períodos iniciais, mesmo porque as alterações vasculares e celulares que levam ao quadro de hialinização tem o início nos primeiros dias após a aplicação da força ortodôntica. Portanto, as observações histológicas nos períodos determinados se referiram æ̀s alterações das estruturas duras ap ós a ocorrência das alterações vasculares e celulares.

Ainda mais, para o procedimento de extrusão ortodôntica aplicourse a distância de $3 \mathrm{~mm}$ e a força de tracionamento pesada tendo como objetivo a extrusão rápida, força esta acima dos níveis considerados como ótimo para o comportamento fisiológico. Segundo PROFFIT \& FIELDS Jr. ${ }^{69}$ (2002), a força ortodôntica pesada nos movimentos de inclinação, de corpo, verticalização, rotação e intrusão promove alterações intensas no periodonto. Inicialmente ocorre a redução no fluxo sanguíneo nas áreas comprimidas do ligamento periodontal, até o ponto em que os vasos sofrem colapso, e sem fluxo sanguíneo é levado a um estado de hialinização. Em 7 a 14 dias poderá ocorrer reabsorção solapante removendo a lâmina dura adjacente à área comprimida no ligamento periodontal.

Entretanto, diferentemente dos movimentos supra-citados, o movimento de extrusão dentária idealmente não deveria produzir áreas de compressão no ligamento periodontal e sim somente áreas de tensão, não havendo assim, alterações de hialinização do ligamento periodontal e seus efeitos. Mas isto ocorreria se a raiz fosse cônica e uniforme, o que não aconteceu para os dentes do experimento. A anatomia radicular mostrou curvatura no 
sentido vestíbulo-lingual, além do achatamento proximal destes dentes. Esta variação anatômica pode ter contribuído nas pequenas e localizadas áreas de compressão. Ainda mais, mesmo em área de tensão pode ocorrer alterações vasculares e celulares, mesmo que seja em menor quantidade se comparado à área de pressão.

As reparações de reabsorção de superfície ocorridas nos diferentes terços no grupo controle pode sugerir interferência da curvatura vestíbulo-ligual da raiz. No movimento dentário coronal, algumas áreas do ligamento poderiam ter sofrido pressão alterando o seu comportamento junto à raiz. Entretanto, isto não exime a parcela de participação da força ortodôntica aplicada.

Os resultados do grupo controle (extrusão ortodôntica) mostram a importância e necessidade de controle adequado da força de tração coronária e a compreensão da anatomia radicular, para evitar reabsorções radiculares nos diferentes terços da raiz. Independentemente da ausência da ruptura do ligamento periodontal, as alterações de superfície da raiz foram constantes nos períodos de 45 a 180 dias. Mais uma vez, a aparência de um ligamento periodontal íntegro junto à camada cementária não significou normalidade absoluta para impedir a deflagração da atividade de reabsorção. É bem possível que esta atividade de reabsorção se relacione com o trauma físico pela ativação pesada com o elástico ortodôntico e a produção de áreas de compressão em função da variação anatômica. Entretanto, ainda seria possível declarar como positivos os resultados visualizados porque, em primeiro ugar a reparação das reabsorções de superfície variou de discreta a moderada; em segundo, toda a ocorrência das reabsorções foram de superfície; em terceiro, todas as lacunas de 
reabsorção de superfície foram reparadas por novo cemento e ligamento periodontal; e em quarto, o grau de envolvimento desta reabsorção em todas amostras neste grupo foi menor que no grupo experimental.

As reabsorções de superfície ativa foram observadas somente nos períodos iniciais da cicatrização e foram transitórias. Como o grupo controle foi avaliado a partir do término da movimentação, esta atividade não foi possível de ser observada neste grupo. Já no grupo experimental esta atividade foi observada e estava associada às áreas com exposição da estrutura mineralizada do cemento e/ou da dentina, porém com o ligamento periodontal normal ao seu redor. As células gigantes multinucleadas de reabsorção foram encontradas nas lacunas de reabsorção ou próximo delas (Figura 15 ). Este tipo de reabsorção foi observada nos períodos de 7,14 e 45 dias da extrusão cirúrgica e ainda a sua atividade variou de discreta a moderada, compreendendo áreas isoladas e em poucas amostras (Gráfico 3 e 5).

$\mathrm{Na}$ avaliação, utilizando a média de 12 amostras por segmento de raiz, foram observados diferentes graus de atividade de reabsorção. No período inicial de 7 dias do grupo experimental, a reabsorção de superfície ativa compreendeu somente o terço apical, sendo $42 \%$ de grau 2 e $13 \%$ de grau 3 das amostras (Gráfico 1). Enquanto que no período de 14 dias, as amostras envolvidas com reabsorção de superfície ativa foram grau 1 sendo $45 \%$ no terço coronal e $27 \%$ no médio aproximadamente, a reabsorção de superfície ativa grau 2 foi observada somente no terço coronal com $18 \%$ de envolvimento das amostras (Gráfico 3). Também foi observada no período de 45 dias o 
envolvimento de aproximadamente $57 \%$ das amostras do terço coronal com reabsorção de superfície ativa grau 1 (Gráfico 5).

Pela observação isolada desta ocorrência histológica poder-se-ia supôr que tivesse papel irrelevante dentro do processo de cicatrização. Todavia, o que se viu nos períodos tardios foi alteração significativa nas amostras analisadas; apesar de não apresentar mais a atividade de reabsorção, áreas de reparação das lacunas de reabsorção de superfície foram visíveis em todos os períodos a partir de 45 dias e de intensidade maior que a apresentada nos períodos iniciais, inclusive com envolvimento de todos os segmentos da raiz. Isso demonstra claramente a falha em observar os eventos histológicos com intervalos prolongados, pois a atividade de reabsorção estivera presente nesses intervalos de observação.

A compreensão da importância do processo de reabsorção de superfície após a extrusão cirúrgica pode ser verificado através da análise dos gráficos 5,7,9 e 11. A quantidade de reparação das reabsorções de superfície em todos os terços da raiz com a variação de grau de discreto a intenso, demonstra que o procedimento cirúrgico de extrusão com ruptura do ligamento periodontal leva automaticamente à deflagraç ão da atividade de reabsorção a partir de 7 dias, podendo perdurar nos períodos mais avançados mesmo com a manutenção do ligamento periodontal junto àcamada cementária aparentemente intactos.

Na extrusão cirúrgica, o envolvimento nos diferentes segmentos da raiz, com variados graus de reparação da reabsorção de superfície, não foi uniforme e alternou nos terços coronal, médio e apical. Esta variação pode sugerir 2 motivos: primeiro, a falta de padronização no nível de agressão física 
que ocorre no ato cirúrgico, pela dificuldade operatória e pela variação anatômica dentária e óssea; e em segundo, a falta de padronização no posicionamento da raiz no alvéolo, o espaço periodontal tridimensional não foi uniforme. Após a extrusão dentária imediata a raiz estava literalmente suspensa e envolvida somente por coágulo. Por esta razão, o espaço periodontal foi mal dividido, tendo áreas mais amplas e outras mais estreitas. Assim, em certas áreas houve aproximação maior com a parede óssea alveolar, sendo possível observar áreas de intensa atividade de reabsorção óssea nestas regiões nos períodos iniciais. Esta falta de padronização de posicionamento da raiz no alvéolo fez com que houvesse grande variação das ocorrências histológicas em diversas superfícies ao redor do dente. Por este motivo não se pôde fazer análise comparativa com os resultados de reimplante dentário imediato, onde as superfícies de maior envolvimento foram vestibular e lingual (ANDREASEN ${ }^{8}, 1980 ;$ ANDREASEN $^{9}$, 1980; ANDREASEN $\left.{ }^{10}, 1981\right)$.

No grupo controle, a reabsorção de superfície ativa não foi observada nos períodos avaliados. Apesar desta aparência, a reabsorção estivera presente. Esta condição pode ser confirmada pela observação das reparações das reabsorções de superfície a partir de 45 dias (Figuras 37 e 38).

Apesar do menor grau de envolvimento por reparação da reabsorção de superfície no grupo controle em comparação ao grupo experimental, os períodos de 45, 90, 120 e 180 dias mostraram progressivamente algum grau de comprometimento, exceto no último quando houve diminuição.

No período de 45 dias, a reparação de reabsorção de superfície grau 2 ocorreu nos terços médio e apical com envolvimento de $27 \%$ das 
amostras (Gráfico 6). Esta observação demonstra que a atividade de reabsorção de superfície iniciou tão precocemente quanto nos dentes que foram submetidos ao procedimento de extrusão cirúrgica, ainda que estas não tenham sido detectadas nos períodos iniciais.

Segundo AUYEUNG, BOUWSMA \& POLSON²2 (1988), a região do ápice radicular é normalmente recoberta por cemento celular, que por sua vez tem inserção reduzida de fibras ou ainda parte deste pode estar livre de inserção. Esta variação biológica pode explicar a ocorrência freqüente de pequenas áreas de reabsorção e talvez por isso também estas regiões se tornem tão suscetíveis à reabsorção após o movimento ortodôntico. Esta afirmação pode ser corroborada analisando os grupos controle e experimental. As reparações de reabsorção de superfície nos terços apicais ocorreram em todos os períodos de observação em ambos os grupos, havendo aí também concentração maior deste evento histológico. Apesar disso, a reparação das reabsorções de superfície foi constante em todos os terços na maioria das amostras analisadas, também havendo variação no grau de envolvimento desta reparação.

Os achados histológicos da reparação de reabsorção de superfície foram interessantes. Todas as cavidades ou lacunas de reabsorção em nível de cemento ou dentina foram preenchidas por cemento novo, inicialmente não funcional e com fibras colágenas dispostas paralelamente à raiz, porém, nos períodos mais avançados de ambos os grupos este cemento passou a ser funcional e apresentou tecido conjuntivo denso e inserido na sua superfície, embora não regenerado. Mesmo com o restabelecimento do periodonto nas áreas que sofreram reabsorções prévias, foi possível observar a irregularidade do 
contorno da raiz que fora determinada pela atividade de reabsorção. Esta condição corrobora achados anteriores em que dentes extraídos, com concavidades experimentais realizadas na raiz e que foram empregados para 0 estudo da cicatrização periodontal, demonstraram que a formação de cemento reparativo é achado constante sobre a superfície dentinária exposta aos tecidos moles (ANDREASEN \& KRISTERSON ${ }^{20}, 1981$; BLOMLÖF, LINDSKOG \&HAMMARSTRÖM ${ }^{27}, 1988$; LINDSKOG, BLOMLÖF \& HAMMARSTRÖM ${ }^{54}$, $1983)$.

Em um outro aspecto, pode-se dizer que a atividade de reabsorção de superfície é temporária ou transitória e que no decorrer da cicatrização toda e qualquer atividade de reabsorção cessa e é reparada por completo. Segundo TRONSTAD $^{81}$ (1988), os tecidos mineralizados desnudos da superfície radicular atraem células de origem clástica inicialmente, porém estas requerem estímulo contínuo durante a fagocitose, e a estimulação da superfície radicular desnuda parece não ser suficiente para sustentar o processo de reabsorção por mais de 2 a 3 semanas. Provavelmente não houve a estimulação contínua das células clásticas, por isso ocorreu a reparação total em ambos os grupos. Assim, œ resultados deste estudo corrobora o trabalho anteriormente citado.

Há ainda evidência de que a reinserção periodontal possa ocorrer mesmo na presença de abcesso periapical e necrose pulpar, desde que o reimplante ocorra imediatamente após a exodontia( ANDERSON, SHARAV \& MASSLER ${ }^{1}$,1968). Algumas amostras do presente estudo, no período de 7 dias da extrusão cirúrgica, mostraram intensa inflamação e degeneração das fibras do ligamento periodontal devido à própria ruptura. Mesmo assim, aparentemente 
todo o ligamento periodontal junto à camada cementária foi conservado e inalterado (Figura 11).. Nos períodos mais avançados o infiltrado inflamatório crônico no ligamento periodontal do terço apical foi observado em algumas amostras. Mesmo na presença da degeneração do colágeno devido à atividade inflamatória, o ligamento periodontal adjacente àraiz foi mantido e permaneceu intacto (Figuras 31, 41, 55).

Uma outra observação histológica foi a reabsorção inflamatória, que segundo ANDREASEN ${ }^{13}$ (1981) pode ser atribuida à rea bsorção de superfície que tem o contato com o tecido pulpar necrótico e infectado através dos túbulos dentinários. As bactérias e seus produtos são suspeitos na manutenção da inflamação crônica dentro do ligamento periodontal, os quais estimulariam as células de origem clástica junto à superfície da raiz. Além disso, há outro fator importante no desenvolvimento deste tipo de reabsorção que, ainda segundo ANDREASEN $^{8}$ (1980), é o fato do movimento de rotação da raiz no interior do alvéolo podem criar áreas de compressão em áreas convexas da raiz, consequentemente provocando sobre o ligamento periodontal forças de compressão extensa e dano celular, o que justificaria o início da atividade desta reabsorção.

As reabsorções inflamatórias foram observadas somente no grupo experimental. As lacunas no cemento e na dentina com a degeneração do colágeno do ligamento periodontal, devido àpresença do infiltrado inflamatório e das células gigantes multinucleadas, foram evidentes nas reabsorções inflamatórias ativas. Esta atividade foi encontrada nos períodos de 14 e 45 dias e somente no terço coronal (Figura 22). 
Por outro lado, as reparações das reabsorções inflamatórias discretas foram observadas no período de 90 e 180 dias distribuídas nos terços médio e apical. As cavidades de reabsorção inflamatória foram reparadas com novo cemento e ligamento periodontal não funcional, com a presença de infiltrado inflamatório crônico difuso. No entanto, é importante ressaltar que todas as lacunas de reabsorção foram reparadas no período de 180 dias, interrompendo assim a atividade de reabsorção (Figura 55). O mesmo aconteceu para reabsorção de superfície neste período. A diferença entre elas foi na proporção da ocorrência das reabsorções que se observa no gráfico 11.

Na observação das reabsorções inflamatórias ativas e a reparação das mesmas, verificou-se que foram discretas e isoladas em poucas amostras. $O$ envolvimento discreto deste tipo de reabsorção se deve provavelmente à ampla manutenção da vitalidade do ligamento periodontal, apesar da agressão física na avulsão da raiz.

É importante salientar que o trauma físico sobre o ligamento periodontal leva invariavelmente ao processo de reabsorção, seja pelo movimento ortodôntico ou pela extração dentária, ocorrência esta que pôde ser observada em todos os grupos avaliados neste estudo. Apesar dos cuidados cirúrgicos no ato da exodontia da raiz, desde a luxação à avulsão desta, a deflagração da atividade de reabsorção foi inevitável. Sendo assim, o conhecimento específico da forma anatômica da raiz e o aprimoramento técnico operatório para minimizar trauma físico, faz-se necessário para prevenir as reabsorções dentárias. 
Ainda mais, a importância da manutenção da integridade e vitalidade do ligamento periodontal em reimplantes e transplantes dentários parece ser inquestionável. Sua presença pode indicar o grau de sucesso de um reimplante ou transplante dentário, avaliado através da reinserção das fibras. Além do mais, a vitalidade do ligamento periodontal foi estabelecida como fator importante para impedir a reabsorção em dentes reimplantados(ANDERSON, SHARAV \& MASSLER ${ }^{1}, 1968$;ANDREASEN ${ }^{6}, 1980 ;$ ANDREASEN $^{10}, 1981$; ANDREASEN \& KRISTERSON ${ }^{18}, 1981$; LÖE \& WAERHAUG ${ }^{56}, 1961$; VAN HASSEL, OSWALD \& HARRINGTON $\left.{ }^{82}, 1980\right)$.

É notável a presença de restos epiteliais de Malassez no ligamento periodontal normal, mas a função exata destas células não é conhecida e há controvérsia sobre a sua atividade e a importância na cicatrização do ligamento periodontal (SPOUGE $\left.{ }^{75}, 1980\right)$.

Para alguns a presença dos restos epiteliais de Malassez no ligamento periodontal pode sugerir um papel importante na resistência da superfície radicular ao processo de reabsorção radicular (LINDSKOG, BLOMLÖF \& HAMMARSTROM ${ }^{55}$,1988) e para outros as células epiteliais são capazes de produzir fatores de crescimento epidermal, substâncias potencialmente capazes de promover reabsorção óssea (BIREK et $\left.\mathrm{al}^{24}, 1983\right)$. Ainda, na análise de LÖE \& WAERHAUG ${ }^{56}(1961)$, os restos epiteliais de Malassez poderiam atuar como fator limitador da reabsorção radicular em dentes reimplantados. Estas células foram associadas ao ligamento periodontal normal de dentes reimplantados, enquanto que em outras áreas onde não eram presentes, observaram remanescentes do ligamento periodontal desorganizado com algum tipo de reabsorção radicular. 
Em todos os dentes dos grupos controle e experimental foi observada a presença constante de células epiteliais dos restos de Malassez adjacente à superfície da raiz saudável e normal que não sofreu nenhum tipo de alteração na sua superfície(Figuras 16, 29, 36, 51). Por outro lado, em áreas da raiz que apresentavam algum tipo de reabsorção ou da sua reparação, estas células não foram encontradas. Mesmo com a ocorrência da reparação funcional, ou seja, formação de cemento novo sobre a lacuna de reabsorção e inserção de novo ligamento periodontal denso, as células epiteliais dos restos de Malassez não foram vistas. Esta observação corrobora os achados de GILHUUS-MOE \& $\mathrm{KVAM}^{34}$ (1972), que os restos epiteliais da bainha de Hertwig, se destruídos, desaparecem definitivamente no local da agressão.

É interessante observar a reparação das reabsorções radiculares mesmo na ausência das células epiteliais nestes locais. Toda e qualquer atividade de reabsorção foi interrompida e a reparação funcional do periodonto foi restabelecida conforme os avanços no período da cicatrização, o que ocorreu em ambos os procedimentos de extrusão dentária.

A administração de antibiótico é usualmente recomendada quando da reimplantação de um dente avulsionado por trauma, prevenindo assim a contaminação bacteriana. As bactérias e outras formas de contaminação sobre a superfície radicular traumatizada podem ter conseqüências potencialmente danosas.

Por outro lado, existe a hipótese de atividade anti-reabsorvitiva dos antibióticos; os antibióticos têm sido muito mais do que simples contenção bacteriana. A penicilina e tetraciclina podem apresentar efeito inibitório na 
atividade de colagenase e osteoclasia, prevenindo assim, a reabsorção inflamatória nos dentes reimplantados imediatamente (HAMMARSTRÖM et al. ${ }^{36}, 1986$; SAE-LIM et al. $\left.{ }^{72}, 1998\right)$.

No presente estudo todos os animais em ambos grupos receberam dose única de 400.000 U.I. de Penicilina G. Benzatina, recomendado pela Faculdade de Medicina Veterinária da PUCPR, com o objetivo de prevenir a contaminação durante 0 ato operatório, como também, no período pós operatório imediato. Como houve administração de antibiótico nos dois grupos, não foi possível avaliar a efetividade deste no controle da atividade de reabsorção. Para tal, pode-se sugerir um estudo controlado com aplicação de antibióticos e concentrações diferentes na prevenção de reabsorções radiculares.

O comportamento dos tecidos periodontais após a extrusão cirúrgica e ortodôntica com força pesada demonstra a viabilidade de aplicação clínica, apesar das ocorrências histológicas de reabsorções radiculares. $\mathrm{O}$ envolvimento por diferentes reabsorções não causaram danos morfo-funcionais a ponto de inviabilizar os procedimentos clínicos. Todas as mudanças iniciais ocorridas em ambos os grupos foram reparadas por periodonto funcional nos períodos mais avançados.

Numa análise comparativa pode se dizer que a extrusão ortodôntica é mais conservadora e fisiológica do que a extrusão cirúrgica, porém os resultados finais mostraram que em ambos grupos o periodonto foi restabelecido, não havendo prejuízo na sua função. Assim sendo, após esta avaliação histológica é possível confirmar a aplicabilidade clínica do procedimento cirúrgico de extrusão dentária como uma opção terapêutica periodontal. 


\section{CONCLUSÕES}




\section{7 - CONCLUSÕES}

Conforme os resultados obtidos pela metodologia e amostra aplicadas, tendo-se presente os conceitos abordados na discussão, são válidas as seguintes conclusões:

1. Apesar da manutenção da integridade do ligamento periodontal adjacente à superfície radicular com ruptura do mesmo na extrusão cirúrgica e sem evidência de ruptura na extrusão ortodôntica, o processo de trauma físico promove a deflagração da atividade de reabsorção da superfície radicular, mesmo que a solução de continuidade da camada cementária não seja visualizada nos períodos iniciais.

2. Independentemente da localização e extensão das reabsorções, seja de superfície ou inflamatória, o período da sua atividade após extrusão cirúrgica ou ortodôntica é limitado e transitório e além disso, todas as cavidades ou lacunas de reabsorção são reparadas pela deposição de novo cemento e ligamento periodontal durante a cicatrização.

3. A reparação inicial das reabsorções não é funcional e se tornará funcional a partir do período mais avançado de 180 dias em ambos os grupos de extrusão.

4. A presença das células epiteliais dos restos de Malassez é constante junto à superfície radicular e ligamento periodontal normais. No entanto, em áreas de reabsorção radicular e/ou da reparação não funcional e funcional não é observada a presença destas células. 
5. A ancilose é ocorrência histológica insignificante no procedimento de extrusão cirúrgica. Isso se deve provavelmente pela manutenção da vitalidade do ligamento periodontal associada àestimulação funcional e fisiológica da raiz.

6. O conhecimento da anatomia radicular, como também do aprimoramento técnico operatório para minimizar trauma físico faz-se necessário para prevenir as reabsorções dentárias.

7. A extrusão ortodôntica rápida promove reabsorção de superfície e também é reparada nos terços avaliados em períodos diferentes.

8. Comparativamente, a extrusão ortodôntica promove menor alteração histológica do que a cirúrgica e pode ser considerada mais conservadora. Todavia, levando em conta a cicatrização final, não há diferença entre os dois grupos. Todas as reabsorções radiculares são reparadas funcionalmente. Sob o ponto de vista de aplicabilidade clínica, ambos os procedimentos podem oferecer resultados satisfatórios. 


\section{REFERÊNCIAS BIBLIOGRÁFICAS}




\section{REFERÊNCIAS BIBLIOGRÁFICAS}

01. ANDERSON, A.W.; SHARAV, Y.; MASSLER,M. Periodontal reattachment after tooth replantation. Periodontics, v. 6, n.4, p. 161-7, 1968.

02. ANDERSSON, L.; BLOMLÖF, L.; LINDSKOG, S.; FEIGLIN, B. \& HAMMARSTRÖM, L.. Tooth ankylosis. Clinical, radiographic and histological assesments. Int. J. Oral. Surg., v. 13, n. 5, p. 423-31, 1984.

03. ANDERSSON, L. \& BODIN, I.. Avulsed human teeth replanted within 15 minutes - a long term clinical follow-up study. Endod. Dent.Traumatol., v.6, n.1, p.37-42,1990.

04. ANDERSSON, L.; LINDSKOG, S.; BLOMLÖF, L.; HEDSTRÖM, K.G. \&HAMMARSTRÖM, L. Effect of mastigatory stimulation on dentoalveolar ankylosis after axperimental tooth replantation. Endod. Dent.Traumatol., v. 1, n.1, p. 13-6, 1985.

05. ANDREASEN, J.O. The effect of splinting upon periodontal healing after replantation of permanent incisors in monkeys. Acta Odont. Scand., v. 33, n.6, p. 313-323, 1975.

06. ANDREASEN, J.O. A time-related study of periodontal healing and root resorption activity after replantation of mature permanent incisors in monkeys. Swed. Dent. J., v. 4, n.3, p. 101-10, 1980.

07. ANDREASEN, J.O. The effect of removal of the coagulum in the alveolus before replantation upon periodontal and pulpal healing of mature permanent incisors in monkeys. Int. J. Oral Surg., v.9, n.6, p.45861,1980 . 
08. ANDREASEN, J.O. Analysis of topography of surface and inflammatory root resorption after replantation of mature permanent incisors in monkeys. Swed. Dent. J., v.4, n.4, p.135-144, 1980.

09. ANDREASEN. J.O. Analysis of pathogenesis and topography of replacement root resorption (ankylosis) after replantation of mature permanent incisors in monkeys. Swed. Dent. J., v.4, n.5, p.231-40,1980.

10. ANDREASEN, J.O. Relationship between cell damage in the periodontal ligament after replantation and subsequent development of root resorption. A time related study in monkeys. Acta Odont. Scand., v. 39, n.1, p. 15-25,1981.

11. ANDREASEN, J.O. Effect of extra-alveolar period and storage media upon periodontal and pulpal healing after replantation of mature permanent incisors in monkeys. Int. J. Oral Surg., v. 10, n.1, p. 43-53, 1981.

12. ANDREASEN, J.O. Periodontal healing after replantation and autotransplantation of incisors in monkeys. Int. J. Oral Surg., v. 10, n.1, p. 54-61, 1981.

13. ANDREASEN, J.O. Relationship between surface and inflammatory resorption and changes in the pulp after replantation of permanent incisors in monkeys. J. Endod., v.7, n.7, p.294-301, 1981.

14. ANDREASEN, J.O. The effect of excessive oclusal trauma upon periodontal healing after replantation of mature permanent incisors in monkeys. Swed. Dent. J., v.5, n.3, p.115-22, 1981.

15. ANDREASEN, J.O. Experimental dental traumatology: development of a model for root resorption. Endod. Dent. Traumatol., v. 3, n. 6, p. 26987, 1987. 
16. ANDREASEN. J.O.; BORUM, M.K.; JACOBSEN, H.L. \& ANDREASEN, F.M.. Replantation of 400 avulsed permanent incisors. 4. Factors related to periodontal ligament healing. Endod. Dent. Traumatol., v.11, n.2, p.76-89, 1995.

17. ANDREASEN, J.O. \& HJORTING-HANSEN, E. Replantation of theeth. II. Histological study of 22 replanted anterior teeth in humans. Acta. Odontol. Scand., v.24, n.3, p.287-306, 1966.

18. ANDREASEN, J.O. \& KRISTERSON, L. The effect of limited drying or removal of periodontal ligament. Periodontal healing after replantation of mature permanent incisors in monkeys. Acta. Odontol. Scand., v. 39, n.1, p. 1-13, 1981.

19. ANDREASEN, J.O. \& KRISTERSON, L. Repair processes in the cervical region of replanted and transplanted teeth in monkeys. Int. J. Oral Surg., v. 10, n.2, p. 128-36, 1981.

20. ANDREASEN, J.O. \& KRISTERSON, L. Evaluation of different types of autotransplanted connective tissues as potential perodontal ligament substitutes. An experimental replantation study in monkeys. Int. J. Oral Surg., v. 10, n.3, p.189-201, 1981.

21. ANDREASEN, J.O. \& SKOUGAARD, M.R. Reversibility of surgical induced dental ankylosis in rats. Int. J. oral Surg., v. 1, n.2, p. 98-102, 1972.

22. AUYEUNG, L.; BOUWSMA, O.J.; POLSON, A.M. Periodontal fiber attachment and apical root resorption. Endod. Dent Traumatol., v.4, n.5, p.219-225, 1988. 
23. BENENATI, F.W. \& SIMON, J.H.S. Orthodontic root extrusion: its rationale and uses. Gen. Dent., v.34, n.4, p. 285-9, 1986.

24. BIREK, C.; HEERSCHE, J.N.M.; JEZ, D. \& BRUNETTE, D.M. Secretion of a bone resorbing factor by epithelial cells cultured from porcine rests of Malassez. J. Periodont. Res., v.18, n.1, p.75-81, 1983.

25. BLOMLÖF, L.; ANDERSSON, L.; LINDSKOG, S.; HEDSTRÖM, K.G. \& HAMMARSTRÖM, L.. Periodontal healing of replanted monkey teeth prevented from drying. Acta. Odont. Scand., v. 41, n. 2, p.117-23, 1983.

26. BLOMLÖF, L. \& LINDSKOG, S. Quality of periodontal healing II: Dinamics of reparative cementum formation. Swed. Dent. J., v.18, n.5, p.131-8, 1994.

27. BLOMLÖF, L.; LINDSKOG, S.; HAMMARSTRÖM, L. A time-related study of healing in the marginal periodontal/root interface. Swed. Dent. J., v.12, n.3, p.101-12,1988.

28. CASTELLI, W.A.; NASJLETI, C.E.; CAFFESSE, R.G. \& PERES, R.D.. Vascular response of the periodontal membrane after replantation of teeth. Oral Surg., v. 50, n. 5, p. 390-7, 1980.

29. CLARK, K.B. \& HAYES, P.A. A study of the comparative effects of rigid and semi-rigid fixation on healing fractures of the mandible in dogs. J. Bone Joint Surg., v. 45, p. 731-41, 1963.

30. COOKE, M.S. \& SCHEER, B.Extrusion of fractured teeth. The evolution ofpractical clinical techniques. Brit. Dent. J., v. 149, n.2, p. 50-3, 1980. 
31. DE PAOLI, S.; NEVINS, M. \& CAPPETTA, E.G. The biologic width: crown lengthening. In: NEVINS, M. \& MELLONIG, J.T. Periodontal therapy. Clinical approaches and evidence of sucess. Volume 1. Chicago, Quintessence, 1988. Cap 21, p. 319-28.

32. DE WAAL, H. \& CASTELLUCCI, G. The importance of restorative margin placement to the biologic width and periodontal health. Part I. Int. J. Period. Res. Dent., v.13,n.5, p.461-71, 1993.

33. GARGIULO, A.W.; WENTZ, F.M. \& ORBAN, B.. Dimensions and relations of the dentogengival junction in humans. J Periodontol, v. 32, n.3 p. 2617. 1961.

34. GILHUUS-MOE, O. \& KVAM, E. Behaviour of the epithelial remanants of Malassez following experimental movement of rat molars. Acta Odont. Scand., v.30, n.2, p.139-49, 1972.

35. GÜNDAY, M.; SAZAK, H.; TÜRKMEN, C. A scaning electron microscopic study of external root resorption in replanted dog teeth. J. Endod., v.21, n.5, p.269-71, 1995.

36. HAMMARSTRÖM, L.; BLOMLÖF, L.; FEIGLIN, B.; ANDERSSON, L. \& LINDSKOG, S.. Replantation of teeth and antibiotic treatment. Endod. Dent. Traumatol., v. 2, n.2, p. 51-7, 1986.

37. HAMMARSTRÖM, L.; PIERCE,A.; BLOMLÖF,L.;FEIGLIN,B. \& LINDSKOG,S.Tooth avulsion and replantation - A review. Endod. Dent. Traumatol., v. 2, n. 1, p. 1-8, 1986.

38. HAMMER, H. Replantation and implantation of teeth. Int. Dent. J., v.5, n.4, p.439-57, 1955. 
39. HEITHERSAY, G.S. Combined endodontic-orthodontic treatment of transverse root fractured in the region of the alveolar crest. Oral Surg., v. 36, n.3, p.404-15, 1973.

40. INGBER, J.S. Forced eruption: Part I. A method of treating isolated one and two wall infrabony osseous defects- Rationale and case report. J. Periodontol, v. 45, n. 4, p. 199-206. 1974.

41. INGBER, J.S. Forced Eruption: Part II. A Method of treating nonrestorable teeth - Periodontal and Restorative considerations. J Periodontol, v.47, n.4, p. 203-16. 1976.

42. JOHNSON, G.K. \& SIVERS, J. Forced eruption in crown-lengthening procedures. J. prosth. Dent., v.56, n.4, p. 424-7, 1986.

43. KHANBERG, K-E. Intraalveolar transplantation of teeth with crown-root Fractures. J Oral Maxillofac Surg, v. 43, n.1, p. 38-42. 1985.

44. KHANBERG, K-E. Surgical extrusion of root fractured teeth. A follow-up study of two surgical methods. Endod. Dent traumatol., v. 4, n.2, p. 859,1988 .

45. KHANBERG, K-E. Intraalveolar transplantation. I. A 10 year follow-up of a surgical extrusion of root fractured teeth. Swed Dent J., v. 20, n.5, p. 165-72,1996.

46. KHANBERG K-E, WARFVINGE, J \& BIRGERSSON, B. Intraalveolar transplantation (I). The use of autologous bone transplant in the periapical region. Int J Oral Surg, v. 11, n.6, p. 372-9,1982. 
47. KIM. S.H.; TRAMONTINA, V.A.; PASSANEZI, E. New approach using the surgical extrusion procedure as an alternative to the reestablishment of biological width. Int. J. Periodont. Rest. Dent., Accepted for publication January 11, 2002.

48. KIM, S.H.; TRAMONTINA, V.A.; TRAMONTINA, M.A.N.M.; GREGHI, S.L.A. \& PASSANEZI, E.. Procedimento de extrusão cirúrgica como terapêuticaperiodontal alternativa para 0 restabelecimento das distâncias biológicas. J. Clinical. Dentstry - Clínica, v.14, n.5, p.5461, 2001.

49. KNECHT, C.D.; ALLEN, A.R.; WILLIAMS, D.J. \& JOHNSON, J.H. Técnicas fundamentais em cirurgia veterinária. $2^{\mathrm{a}}$ ed., São Paulo, Roca, 1985. p.146-7.

50. KNIGHT, M.K.; GANS, B.J. \& CALANDRA, J.C. The effect of root canal therapy on replanted teeth of dogs. Oral Surg., v.18, n.2, p.227-42, 1964.

51. KRISTERSON, L. \& ANDREASEN, J.O. The effect of splinting upon periodontal and pulpal healling after autotransplantation of mature and immature permanent incisors in monkeys. Int. J. Oral Surg., v. 12, n.4, p.239-49, 1983.

52. LEMON, R.R. Simplifield esthetic root extrusion techniques. Oral Surg., v. 54, n.1, p. 93-9, 1982.

53. LEW, K.K.K. Orthodontically induced microvascular injuries in the tension zone of the periodontal ligament. J. Nihon univ. Sch. Dent., v.31, n.3, p.493-501, 1989. 
54. LINDSKOG, S.; BLOMLÖF, L. \& HAMMARSTRÖM, L. Repair of periodontal tissues in vivo and in vitro. J. clin. Periodont., v.10, n.2 , p.188-205, 1983.

55. LINDSKOG, S.; BLOMLÖF, L. \& HAMMARSTRÖM, L. Evidence for a role of odontogenic epithelium in maintaining the periodontal space. J. Clin Periodont., v.15, n.6, p. 371-3, 1988.

56. LÖE, H. \& WAERHAUG, J. Experimental replantation of teeth in dogs and Monkeys. Arch. Oral Biol., v. 3, n.3, p. 176-84,1961.

57. MAGINI, R.S.; CENSI,J.C.; ZORZO, G. \& SCHIOCHETT, C.. Tracionamento dental imediato. JBC - Jornal Bras. Odonto. Clin., v. 2, n.10, p. 42-8, 1998.

58. MASSLER, M. Tooth replantation. Dent. Clin North Am., v.18, n.2, p.445-52, 1974.

59. MORSE, A. Formic acid-sodium citrate decalcification and butyl alcohol dehydration of teeth abd bones for sectioning in paraffin. J. Dent. Res., v. 24, p.143-53, 1945.

60. NASJLETI, C.E.; CAFFESSE, R.G.; CASTELLI, W.A. \& HOKE, J.A. Healing after tooth reimplantation in monkeys. A radioautographic study. Oral Sug., v.39, n.3, p.361-75,1975.

61. NASJLETI, C.E.; CAFFESSE, R.G.; CASTELLI, W.A. Replantation of mature teeth without endodontics in monkeys. J. Dent. Res., v.57, n.4, p.6508, 1978. 
62. NASJLETI, C.E. ; CASTELLI, W. A. ; CAFFESSE, R.G. The effects of different splinting times on replantation of teeth in monkeys. Oral Surg., v.53, n.6, p.557-66, 1982.

63. NEDER, J.E. Tração coronal: Implicações biológicas e clínicas após 23 anos de estudo retrospectivo. Tese - Faculdade de Odontologia de Bauru - USP, 1996.

64. OCHSENBEN, C. \& ROSS, S.E. A reevaluation of osseous surgery. Dent. Clin. N. Amer., v.13, n.1, p.87-102, 1969.

65. OPPENHEIM, A. Artificial elongation of teeth. Am. J. Orthod. Oral Surg., v.26, n.10, p.931-40, 1940.

66. ORBAN, B. The epithelial network in the periodontal membrane. J. Amer. Dent. Ass., v.44, n.6, p.632-5,1952.

67. PASSNEZI, E.; ALVES, M.E.A.F.; JANSON, W.A. \& NAHÁS, D.. Solução não cirúrgica para problema protético periodontal (nota prévia). Estomat. Cult., v.8, p.287, 1974.

68. PETTIETTE,M.; HUPP,J.; MESAROS, S. \& TROPE, M.. Periodontal healing of extracted dog's teeth air-dried for extended periods and soaked in various media. Endod. Dent. Traumatol., v.13, n.3, p.113-8, 1997.

69. PROFFIT, W.R. \& FIELDS Jr., H.W. Ortodontia Contemporânea, 3aㅗ ed., Rio de Janeiro, Guanabara Koogan, 2002, p.288.

70. RIES, B.J.; JOHNSON, G.K. \& NIELBERG, L.G. Vertical extrusion using a removable orthodontic appliance. J. Amer. Dent. Ass., v.116, n.4, p.521-3, 1988. 
71. SAE-LIM, V.; WANG, C.Y.; CHOOI, G.W. \& TROPE, M.. The effect of systemic tetracycline on resorption of dried replanted dog's teeth. Endod. Dent. Traumatol., v.14, n.3, p.127-132, 1998.

72. SAE-LIM, V.; WANG, C.Y.; TROPE, M. Effect of systemic tetracycline and amoxicillin on inflamatory root resorption of replanted dog's teeth. Endod. Dent. Traumatol., v.14, n.5, p.216-220, 1998.

73. SCHLUGER, S. Osseous ressection - a basic principle in periodontal surgery. Oral Surg., v.2, p.316-25,1949.

74. SIMON, J.H.S.; LYTHGOE, J. \& TORABINEJAD, M. Clinical and histologic evaluation of extruded endodontically treated teeth in dogs. Oral Surg., v.50, n.4, p.361-71,1980.

75. SPOUGE, J.D. A new look at the rests of Malassez. A review of their embryological origin, anatomy, and possible role in periodontal health and disease. J. Periodont., v.51, n.8, p.437-44, 1980.

76. STERN, N. \& BECKER, A. Forced eruption: biologic and clinicalconsiderations.J.oral Rehabil., v.7, n.5, p.395-402, 1980.

77. STEVENS, B.H. \& LEVINE, R.A. Forced eruption: A multidisciplinary approach forform, function, and biologic predictability. Comp. Contin. Educ. Dent., v.19, n.10, p. 994-1010, 1998.

78. STROSTER, T.G. Forced eruption: clinical considerations. Gen. Dent., v.38, n.5, p.376-80, 1990.

79. TEGSJÖ, U.; VALERIUS-OLSSON, H.; FRYKHOLM, A. \& OLGART, K.. Clinical evaluation of intra-alveolar transplantation of teeth with cervical root fractures. Swed Dent J, v. 11, n.5, p. 235-50. 1987. 
80. TEGSJÖ, U.; VALERIUS-OLSSON, H.; OLGART, K. Intra-alveolar transplantation of teeth with cervical root fractures. Swed Dent J, v. 2, n.2, p. 73-82. 1978.

81. TRONSTAD, L. Root resorption - etiology, terminology and clinical manifestations. Endod. Dent. Traumatol., v. 4, n.6, p.241-52, 1988.

82. VAN HASSEL, H.J.; OSWALD, R.J.; HARRINGTON, GW. Replantation 2. The role of the periodontal ligament. J. Endod., v. 6, n. 4, p. 506-8, 1980.

83. VAN VENROOY, J.R. \& YUKNA, R.A. Orthodontic extrusion of single-rotated teeth affected with advanced periodontal disease. Am. J. Orthod., v.87, n.1, p.67-74, 1985.

84. WARFVINGE, J. \& KAHNBERG, K-E. Intraalveolar transplantation of teeth. IV.Endodontic considerations. Swed Dent J, v. 13, n.6, p. 229-33. 1989. 


\section{ABSTRACT}




\section{ABSTRACT}

The invasion of biological width of the marginal periodontium by tooth fractures, caries, subgingival prosthetic preparations and root trepanations cause serious consequences on the periodontal structures.

Usually, in teeth with compromised biological width, different therapeutic approaches are used, such as: apical positioned flap associated with osteotomy, orthodontic extrusion and more recently the surgical extrusion.

The basic concepts of the surgical extrusion are the same as the orthodontic extrusion: to move the root to coronal position, or, in other words, replace the cervical portion of the root to a supragingival position. This treatment would be indicated only in teeth with complete formation of the root apex and with a sufficient root length to support a prosthetic crown.

The surgical extrusion technique was related as an efficient solution to subgingival fractures of anterior teeth in child and in situations of coronal destruction caused by caries in teeth treated with different types of restoration ${ }^{43,44,45,46,47,48,79,80}$.

Although the surgical extrusion technique has clinical effectiveness and some advantages above the orthodontic extrusion, it has been realized based only on the healing process described in the immediate tooth replantation. The healing considerations about this procedure would be used to the surgical extrusion technique because their similarities. 
Both surgical and rapid orthodontic extrusion have no histological considerations described in the literature. The aim of this work was to compare histologically teeth submitted to orthodontic or surgical extrusion in different periods of time.

In this study, 18 male mongrel dogs were randomly selected and separated in 3 group of 6 animals each. In each animal, two procedures were taken: orthodontic extrusion (control side) and surgical extrusion (test side). Endodontic treatment were performed in the lateral incisors previously to the extrusion.

In the control side, rapid orthodontic traction was performed using a force above the physiological levels. Tooth movement was done with rubber rings linked to an intra root post and a transversal bar ( $0.7 \mathrm{~mm}$ orthodontic wire) fixed in the adjacent teeth. Coronal traction was $3 \mathrm{~mm}$ in length and the average time was 3 to 4 weeks.

In the experimental side, surgical extrusion was performed with carefully luxation and avulsion of teeth in the same alveoli in a position $3 \mathrm{~mm}$ coronally. The extracted root was stabilized with interproximal sutures of the flap and an incisal stop was done with orthodontic wire fixed to the adjacent tooth to prevent exfoliation in the initial period.

Animals were sacrificed at $7,14,45,90,120$ and 180 days. The samples were removed and fixed in formalin $10 \%$. Routine laboratorial embedding was performed and cross sections were taken in the coronal, median and apical thirds and stained with hematoxilin and eosin. 
Results showed the importance of maintenance of the vitality of the periodontal ligament and root cement to prevent root resorption. The rupture of periodontal ligament promoted resorption activity and inflammation, observed on the period of 7 and 14 days on the experimental group. The samples of the later periods showed extensive reparation of the resorbed areas in all thirds evaluated. It is important to say that all the cavities caused by resorption were repaired, being initially not functional, but at the final periods they were functional. The ankylosis was not a regular finding.

In control teeth, because of the intense force applied, it was observed some root alterations. Resorption activity was not seen, but in the later periods of sacrifice, it was possible to observe areas of repair of superficial resorptions, showing a negative effect of the rapid orthodontic extrusion. Even though, in the same manner of the experimental side, all superficial areas of resorption healed functionally in the later periods.

Instead of the presence of areas root resorption associated with mechanical trauma (surgical or from orthodontics), the repair of these areas with the establishment of a functional periodontal ligament was achieved, but we can not assume that there was regeneration of the structures.

Within the limits of this study, it was possible to conclude that tooth extrusion, performed by surgical or orthodontic techniques leads to a physiological process of healing, being possible to apply in clinical situations. 


\section{APÊNDICE}




\section{Universidade de São Paulo \\ Faculdade de Odontologia de Bauru}

Al. Dr. Octávio Pinheiro Brisolla, 9-75 - Baunı-SP-CEP 17012-101 - C.P. 73

PABX (0XX14)235-8000 - FAX (0XX14)223-4679

COMISSÃO DE ÉTICA NO ENSINO E PESQUISA EM ANIMAIS

\section{DECLARAÇ̃̃O}

Declaro para os devidos fins que a Comissão de Ética no Ensino e Pesquisa em Animais (CEEPA), da Faculdade de Odontologia de Bauru, da Universidade de Sāo Paulo, foi constituida pela Portaria GD n ${ }^{\circ}$. 001/2003/FOB em 27 de janeiro de 2003.

Por ser a expressāo da verdade, firmo a presente.

Bauru, 26 de fevereiro de 2003.

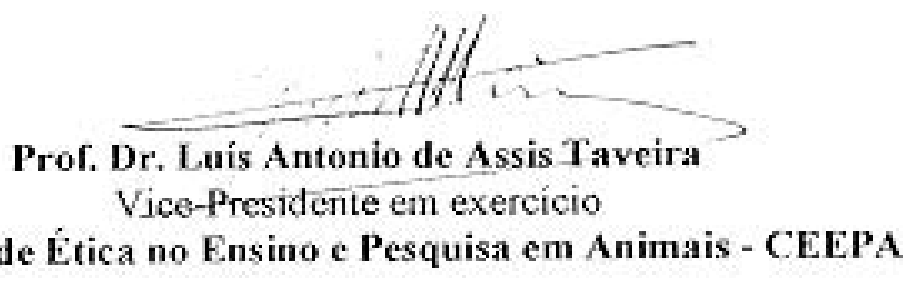

Comissão de Ética no Ensino e Pesquisa em Animais - CEEPA 